\title{
METODICKÉ LISTY PRO PŘEDMĚTY DOKTORSKÉHO STUDIJNÍHO PROGRAMU P6208 EKONOMIKA A MANAGEMENT FAKULTY EKONOMICKÉ ZÁPADOČESKÉ UNIVERZITY V PLZNI
}

Lilia Dvořáková a kolektiv

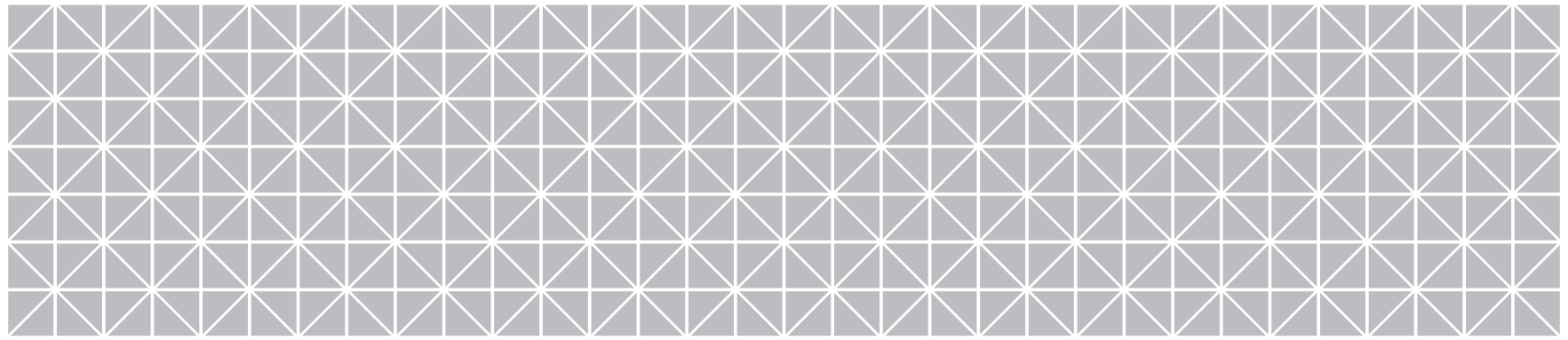




\title{
METODICKÉ LISTY PRO PŘEDMĚTY DOKTORSKÉHO STUDIJNÍHO PROGRAMU P6208 EKONOMIKA A MANAGEMENT FAKULTY EKONOMICKÉ ZÁPADOČESKÉ UNIVERZITY V PLZNI
}

\author{
Lilia Dvořáková a kolektiv
}

Fakulta ekonomická, Západočeská univerzita v Plzni

E-publikace, 2018

https://doi.org/10.24132/ZCU.2018.07590 


\section{Autorský kolektiv (garanti předmětů doktorského studijního programu)}

prof. Ing. Lilia Dvořáková, CSc., vedoucí autorského kolektivu, předmluva, odborná participace na kapitolách $1-3$, shrnutí, celková redakce

prof. Ing. Josef Basl, CSC.

doc. Ing. Petr CIMLER, CSc.

doc. PaedDr. Ludvík Eger, CSc.

doc. PaedDr. Dana Egerová, Ph.D.

doc. RNDr. Mikuláš Gangur, Ph.D.

doc. Ing. Dagmar Jakubíková, Ph.D.

doc. Dr. Ing. Miroslav Plevný

prof. Ing. Ján Pokrivčák, M.S., Ph.D.

RNDr. Jiří Preis, Ph.D.

Ing. Petra Taušl Procházková, Ph.D.

doc. Ing. Jiří Vacek, Ph.D.

Bc. Helena Toncarová, technická podpora

Západočeská univerzita v Plzni

Univerzitní 8, 30614 Plzeň

www.fek.zcu.cz

https://doi.org/10.24132/ZCU.2018.07590

Počet stran: 100

První vydání, Plzeň, leden 2018 


\section{OBSAH}

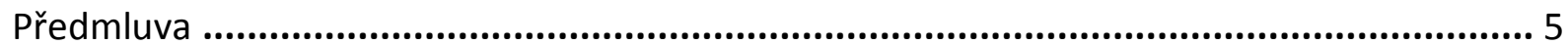

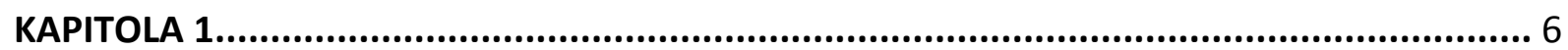

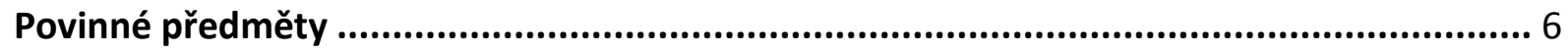

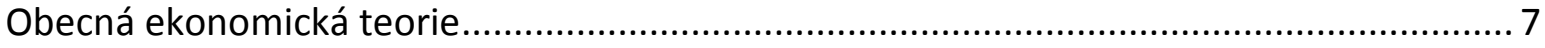

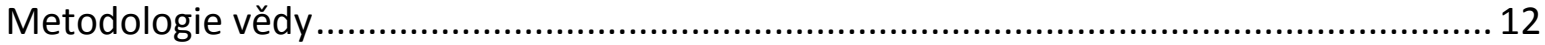

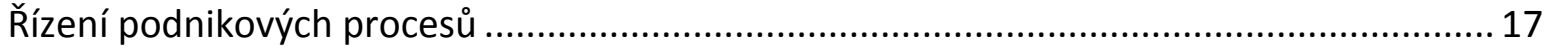

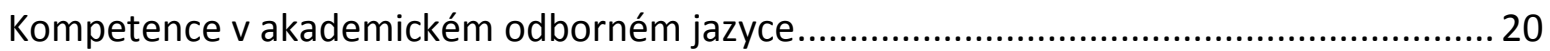

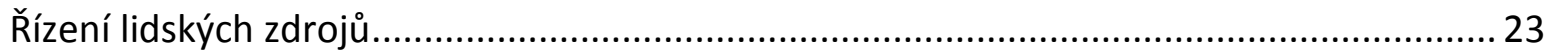

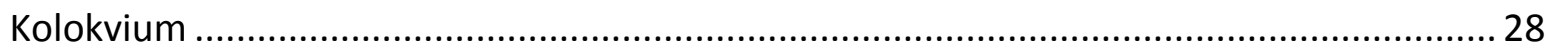

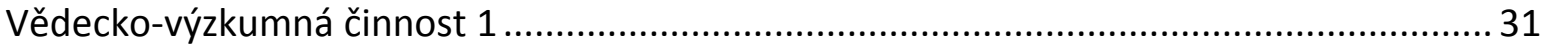

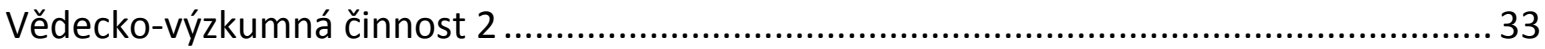

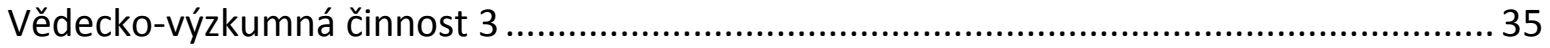

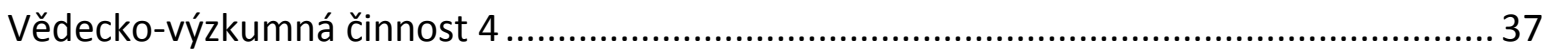

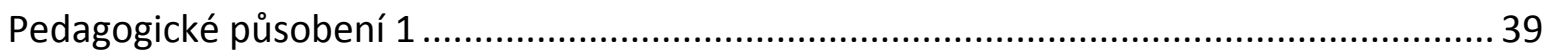

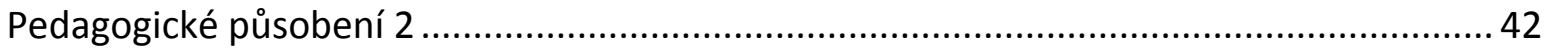

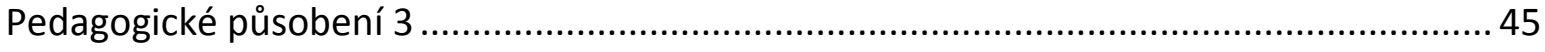

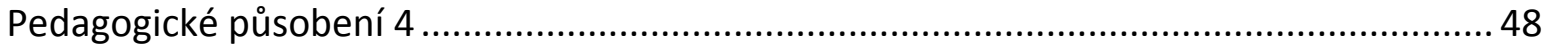

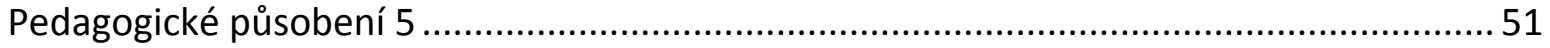

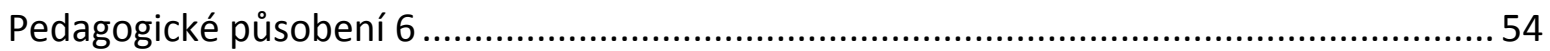

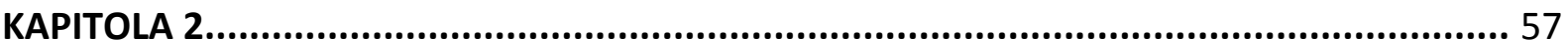

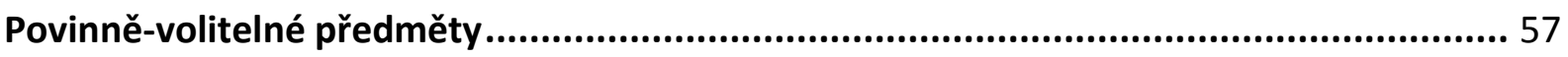

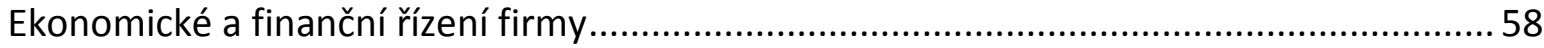

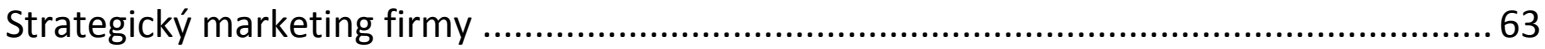

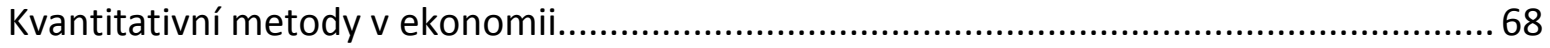

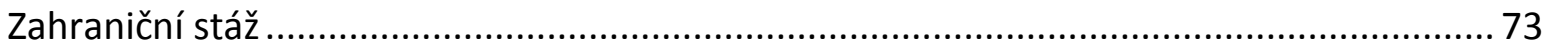

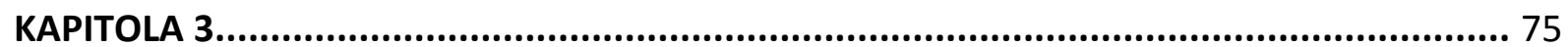

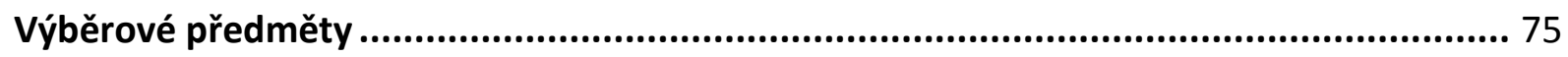

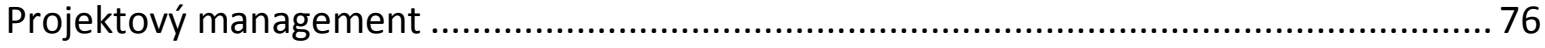

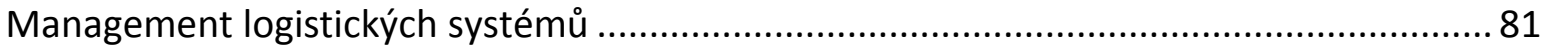




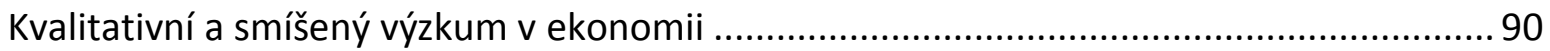

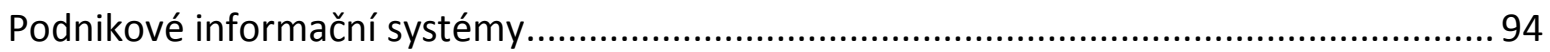

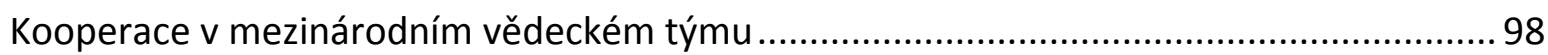

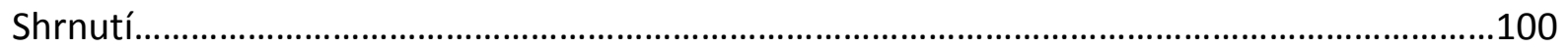




\section{PŘEDMLUVA}

\section{Vážení čtenáři,}

hlavním záměrem publikace Metodické listy pro předměty doktorského studijního programu P6208 Ekonomika a management Fakulty ekonomické, Západočeské univerzity v Plzni je detailně představit čtyřletý doktorský studijní program z hlediska jeho zaměření a obsahu v kontextu kreditního systému studia.

Publikace je rozčleněna do tří kapitol, které představují základní strukturu doktorského studijního programu Ekonomika a management v následujících oblastech:

1. povinné předměty -16 předmětů,

2. povinně-volitelné předměty -4 předměty,

3. výběrové (volitelné) předměty -6 předmětů.

Pro každý předmět je zpracován metodický list, ve kterém je formulován cíl předmětu, obsah předmětu s detailní specifikací, základní a doporučená literatura, požadavky na studenta, forma a rozsah výuky, kontakt na garanta předmětu, způsob ukončení (absolvování) předmětu, počet kreditů a doporučený rok a semestr pro absolvování předmětu.

Publikace je primárně určena studentům čtyřletého doktorského studijního programu P6208 Ekonomika a management na Fakultě ekonomické Západočeské univerzity v Plzni v prezenční a kombinované formě studia a také potenciálním zájemcům o studium tohoto doktorského studijního programu.

Autorský kolektiv publikace (garanti předmětů doktorského studijního programu) uvítá veškeré Vaše připomínky, návrhy a doporučení. Pro tento účel, prosím, využijte e-mailovou adresu: Idvorako@kfu.zcu.cz.

Tato publikace vznikla jako dílčí výstup projektu VS-17-022 „Inovace a príprava nového doktorského studijního programu Ekonomika a management na kreditní systém studia“.

Plzeň, prosinec 2017

prof. Ing. Lilia Dvořáková, CSc.

garant doktorského studijního programu

P6208 Ekonomika a management 


\section{KAPITOLA 1}

\section{Povinné předměty}

\begin{tabular}{|c|c|c|c|c|c|}
\hline \multirow[t]{2}{*}{ Název předmětu } & \multirow{2}{*}{$\begin{array}{l}\text { Zkratka } \\
\text { předmětu }\end{array}$} & \multirow{2}{*}{$\begin{array}{l}\text { Počet } \\
\text { kreditů }\end{array}$} & \multirow{2}{*}{$\begin{array}{c}\text { Zakončeno } \\
\text { (Zp/ Zk) }\end{array}$} & \multicolumn{2}{|c|}{ Doporučeno } \\
\hline & & & & Rok & Semestr \\
\hline Obecná ekonomická teorie & KEM/DOETN & 15 & Zk & 1 & ZS \\
\hline Metodologie vědy & KMO/DMVN & 10 & Zk & 1 & ZS \\
\hline Řízení podnikových procesů & KPM/DPEN & 15 & Zk & 1 & LS \\
\hline $\begin{array}{l}\text { Kompetence } v \text { akademickém } \\
\text { odborném jazyce }\end{array}$ & FEK/DCJN & 10 & $Z p$ & 1 & LS \\
\hline Řízení lidských zdrojů & KPM/DRLZN & 15 & Zk & 2 & ZS \\
\hline Kolokvium & FEK/DKKN & 10 & $Z p$ & 2 & LS \\
\hline Vědecko-výzkumná činnost 1 & FEK/DVVN1 & 10 & $Z p$ & 2 & ZS \\
\hline Vědecko-výzkumná činnost 2 & FEK/DVVN2 & 15 & $Z p$ & 3 & ZS \\
\hline Vědecko-výzkumná činnost 3 & FEK/DVVN3 & 15 & $Z p$ & 3 & LS \\
\hline Vědecko-výzkumná činnost 4 & FEK/DVVN4 & 30 & $Z p$ & 3 & LS \\
\hline Pedagogické působení 1 & FEK/DPPN1 & 5 & $Z p$ & 1 & ZS \\
\hline Pedagogické působení 2 & FEK/DPPN2 & 5 & $Z p$ & 1 & LS \\
\hline Pedagogické působení 3 & FEK/DPPN3 & 5 & $Z p$ & 2 & ZS \\
\hline Pedagogické působení 4 & FEK/DPPN4 & 5 & $Z p$ & 2 & LS \\
\hline Pedagogické působení 5 & FEK/DPPN5 & 5 & $Z p$ & 3 & ZS \\
\hline Pedagogické působení 6 & FEK/DPPN6 & 5 & $Z p$ & 3 & LS \\
\hline $\begin{array}{l}\text { Celkem povinné předměty za celé } \\
\text { studium }\end{array}$ & - & 175 & - & - & - \\
\hline
\end{tabular}




\section{Obecná ekonomická teorie}

\section{METODICKÝ LIST PRO PŘEDMĚT DOKTORSKÉHO STUDIJNÍHO PROGRAMU P6208 EKONOMIKA A MANAGEMENT}

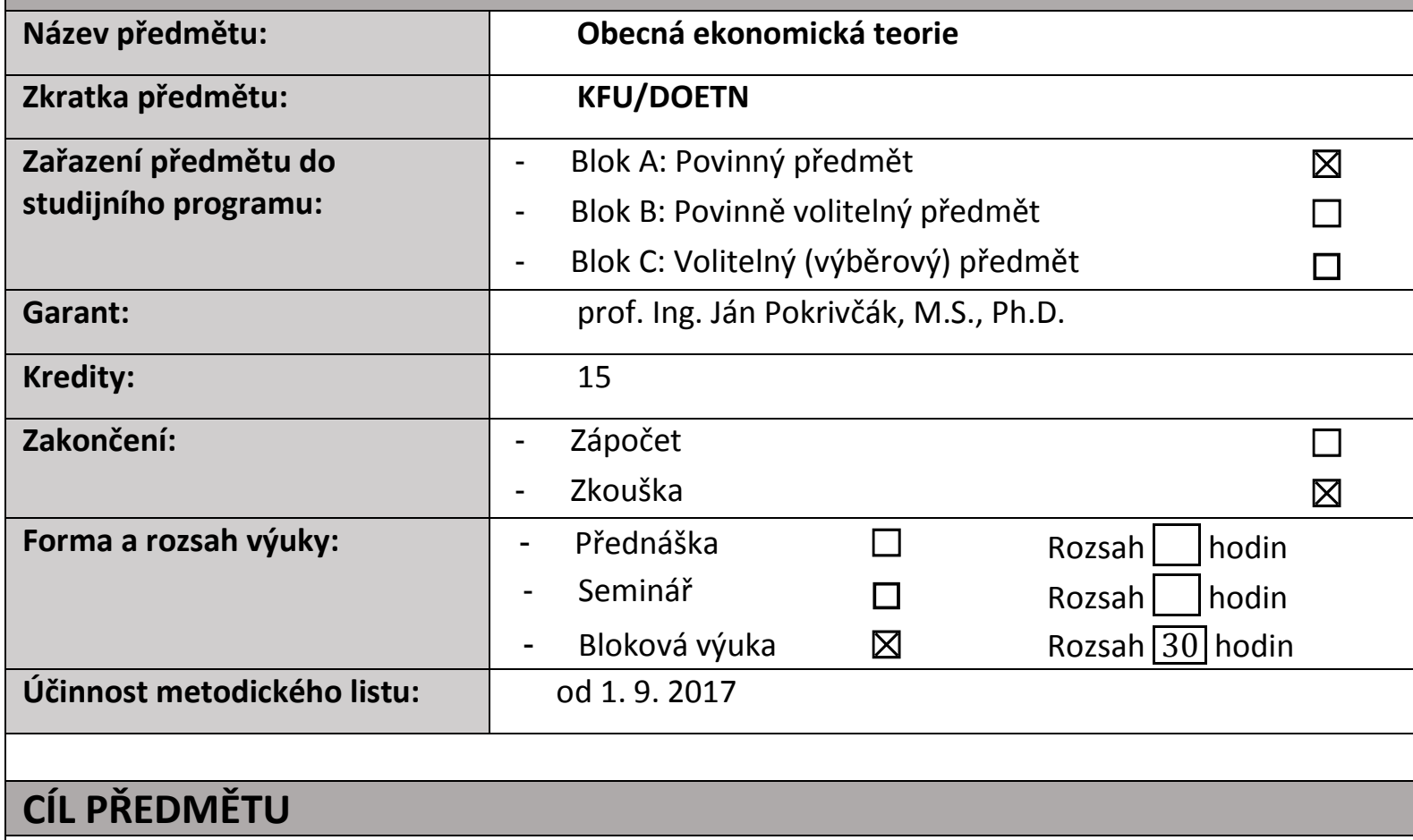

Prohloubit znalosti $\mathrm{v}$ oblasti mikroekonomie a makroekonomie $\mathrm{z}$ magisterského studijního programu. Analyzovat vybrané determinanty chování dílčích trhů i ekonomiky jako celku v krátkém i dlouhém období na základě současného stupně poznání ve světové ekonomické teorii. Správně hodnotit př́činy a následky ekonomických procesů a jejich dopad na podniky. Odlišit pozitivní a normativní př́istup $v$ ekonomické analýze. Aplikovat získané poznatky na téma své disertační práce.

\section{OBSAH PŘEDMĚTU}

1. Teorie chování spotřebitele

2. Teorie chování firmy

3. Modely dokonalé a nedokonalé konkurence

4. Model všeobecné rovnováhy a ekonomie blahobytu

5. Teorie her

6. Ekonomie informací

7. Dlouhodobý ekonomický růst

8. Modely agregátní nabídky

9. Poptávka po penězích a nabídka peněz

10. Agregátní poptávka v otevřené ekonomice

11. Monetaristický koncept rovnováhy platební bilance

12. Monetaristický koncept determinace měnového kurzu 


\section{OBSAH PŘEDMĚTU S DALŠÍ SPECIFIKACÍ}

1. Teorie chování spotřebitele

a) Užitek a preference

b) Volba spotřebitele, poptávka a její vlastnosti

c) Duální úloha minimalizace spotřebních výdajů

\section{Klíčová slova:}

funkce užitku, Hicksova poptávka, Lagrangeova metoda, Marshallova poptávka, nepř́má funkce užitku, výdajová funkce

2. Teorie chování firmy

a) Produkční funkce a její vlastnosti

b) Minimalizace nákladů

c) Maximalizace zisku, funkce zisku a její vlastnosti

\section{Klíčová slova:}

funkce zisku, homogenní funkce, podmíněná poptávka po výrobním faktoru, výnosy z rozsahu

3. Modely dokonalé a nedokonalé konkurence
a) Dokonalá konkurence
b) Monopol a oligopol
c) Monopolistická konkurence

\section{Klíčová slova:}

Bertrandův model, Cournotův model, nulový ekonomický zisk, př́ijemce ceny, tvůrce ceny

4. Model všeobecné rovnováhy a ekonomie blahobytu
a) Rovnováha ve výrobě, rovnováha ve spotřebě
b) Walrasova rovnováha, Walrasův zákon
c) Ekonomie blahobytu

\section{Klíčová slova:}

Edgeworthův box, Paretovská efektivnost, věty ekonomie blahobytu

5. Teorie her
a) Strategické rozhodování
b) Hry ve strategické formě
c) Hry v rozvinuté formě

\section{Klíčová slova:}

dominantní strategie, hry s dokonalými informacemi, hry s nedokonalými informacemi, Nashova rovnováha, smíšené strategie

6. Ekonomie informací
a) Nepřiznivý výběr
b) Morální hazard a problém pán-správce
c) Symetrické a asymetrické informace

Klíčová slova:

filtrování (screening), očekávaný užitek, pojištění, signalizační chování (signalling) 
7. Dlouhodobý ekonomický růst

a) Solowův model, stabilní stav

b) Technologický pokrok rozšiřující práci a neutrální technologický pokrok

c) Modely endogenního růstu

\section{Klíčová slova:}

ekonomický růst, fyzický kapitál, lidský kapitál, pozitivní externality investic do kapitálu, rozdělování produktu, zlaté pravidlo akumulace kapitálu

8. Modely agregátní nabídky

a) Friedmanův a Lucasův koncept agregátní nabídky

b) Teorie reálného hospodářského cyklu

c) Nová keynesiánská makroekonomie, cenové a mzdové rigidity

Klíčová slova:

adaptivní očekávání, cenové rigidity, exogenní technologické šoky, mzdové rigidity, racionální očekávání

9. Poptávka po penězích a nabídka peněz

a) Keynesiánské teorie poptávky po penězích

b) Friedmanova reformulace kvantitativní teorie peněz

c) Koncept exogenních a endogenních peněz

Klíčová slova:

bohatství, kvantitativní rovnice peněz, motivy držby peněz, nabídka peněz, permanentní důchod

10. Agregátní poptávka v otevřené ekonomice

a) Křivka BP v systému fixního a flexibilního měnového kurzu

b) Agregátní poptávka v systému fixního měnového kurzu

c) Agregátní poptávka v systému flexibilního měnového kurzu

Klíčová slova:

agregátní poptávka, kapitálová mobilita, model IS-LM-BP, systémy měnového kurzu

11. Monetaristický koncept rovnováhy platební bilance

a) Předpoklady monetaristického konceptu rovnováhy platební bilance

b) Mechanismus obnovování rovnováhy

c) Komparace monetaristického a keynesiánského konceptu

Klíčová slova:

centrální banka, nabídka peněz, rovnováha platební bilance, rovnováha trhu peněz

12. Monetaristický koncept determinace měnového kurzu

a) Bilsonův a Frenkelův model

b) Dornbuschův model

c) Frankelův model

Klíčová slova:

diferenciál reálných úrokových sazeb, flexibilní ceny, krátkodobě nepružné ceny 


\section{LITERATURA}

\section{Základní:}

Soukup, J. (2003). Mikroekonomická analýza (3. vydání). Slaný: Melandrium.

$\checkmark$ Jehle, A. G. \& Reny, P. J. (2011). Advanced Microeconomic Theory ( $3^{\text {rd }}$ edition). Harlow, England: Financial Times/Prentice Hall.

$\checkmark$ Mach, M. (2002) Makroekonomie: pokročilejší analýza. Slaný: Melandrium.

$\checkmark$ Blanchard. O. \& Johnson, D. R. (2013). Macroeconomics ( $6^{\text {th }}$ edition). Boston: Pearson.

\section{Doporučená:}

$\checkmark$ Holman, R. \& kol. (2017). Dějiny ekonomického myšlení (4. vydání). Praha: C. H. Beck.

$\checkmark$ Sojka, M. (2010). Dějiny ekonomických teorií. Praha: Havlíček Brain Team.

$\checkmark$ Gravelle, H. \& Rees, R. (2004). Microeconomics (3 $3^{\text {rd }}$ edition). Harlow, England: Financial Times/Prentice Hall.

$\checkmark$ Romer, D. (2001). Advanced Macroeconomics (2 $2^{\text {nd }}$ edition). New York: The MacGraw-Hill.

\section{POŽADAVKY NA STUDENTA}

1. Zvládnout předmět $\mathrm{v}$ rozsahu stanoveném sylabem a prokázat vědomosti a dovednosti při kombinované zkoušce, písemnou prací (aplikace ekonomické teorie a téma disertační práce).

2. Nastudovat samostatně doporučenou literaturu.

3. Zkouška je kombinovaná a skládá se ze dvou částí (mikroekonomie a makroekonomie), jež je možno skládat odděleně.

4. Zpracovat písemnou práci (výzkumnou esej) na vybranou oblast ekonomické teorie aplikovanou na téma disertační práce. Vybrané téma a zaměření výzkumné eseje je nutné předem konzultovat s garantem předmětu. Rozsah výzkumné eseje je 20 - 30 normostran.

5. Prokázat získané znalosti, vědomosti a dovednosti při prezentaci a diskusi výsledků výzkumné eseje a kontrolních otázek v rozsahu tématu eseje.

\section{FORMA A ROZSAH VÝUKY}

Výuka predmětu probíhá formou blokové prezenční výuky (30 hodin) a individuálních konzultací.

1. Obsah 1. výukového bloku, rozsah 5 hodin
a) Užitek a preference
b) Volba spotřebitele, poptávka a její vlastnosti
c) Duální úloha minimalizace spotřebních výdajů
d) Produkční funkce a její vlastnosti
e) Minimalizace nákladů
f) Maximalizace zisku, funkce zisku a její vlastnosti

2. Obsah 2. výukového bloku, rozsah 5 hodin
a) Dokonalá konkurence
b) Monopol a oligopol
c) Monopolistická konkurence
d) Rovnováha ve výrobě, rovnováha ve spotřebě
e) Walrasova rovnováha, Walrasův zákon
f) Ekonomie blahobytu 
3. Obsah 3. výukového bloku, rozsah 5 hodin
a) Strategické rozhodování
b) Hry ve strategické formě
c) Hry v rozvinuté formě
d) Nepř́źnivý výběr
e) Morální hazard a problém pán-správce
f) Symetrické a asymetrické informace

4. Obsah 4. výukového bloku, rozsah 5 hodin
a) Solowův model, stabilní stav
b) Technologický pokrok rozšiřující práci a neutrální technologický pokrok
c) Modely endogenního růstu
d) Friedmanův a Lucasův koncept agregátní nabídky
e) Teorie reálného hospodářského cyklu
f) Nová keynesiánská makroekonomie, cenové a mzdové rigidity

5. Obsah 5. výukového bloku, rozsah 5 hodin
a) Keynesiánské teorie poptávky po penězích
b) Friedmanova reformulace kvantitativní teorie peněz
c) Koncept exogenních a endogenních peněz
d) Křivka BP v systému fixního a flexibilního měnového kurzu
e) Agregátní poptávka v systému fixního měnového kurzu
f) Agregátní poptávka v systému flexibilního měnového kurzu

6. Obsah 6. výukového bloku, rozsah 5 hodin

a) Předpoklady monetaristického konceptu rovnováhy platební bilance

b) Mechanismus obnovování rovnováhy platební bilance

c) Komparace monetaristického a keynesiánského konceptu rovnováhy platební bilance

d) Bilsonův a Frenkelův model determinace měnového kurzu

e) Dornbuschův model determinace měnového kurzu

f) Frankelův model determinace měnového kurzu

\section{DALŠí INFORMACE GARANTA PŘEDMĚTU}

\section{KONTAKT NA GARANTA PŘEDMĚTU}

jpokriv@kem.zcu.cz

+420377633101

(dle aktuálního zadání na www.fek.zcu.cz)

UK 419 , FEK ZČU, Univerzitní 22, 30614 PIzeň 
Metodologie vědy

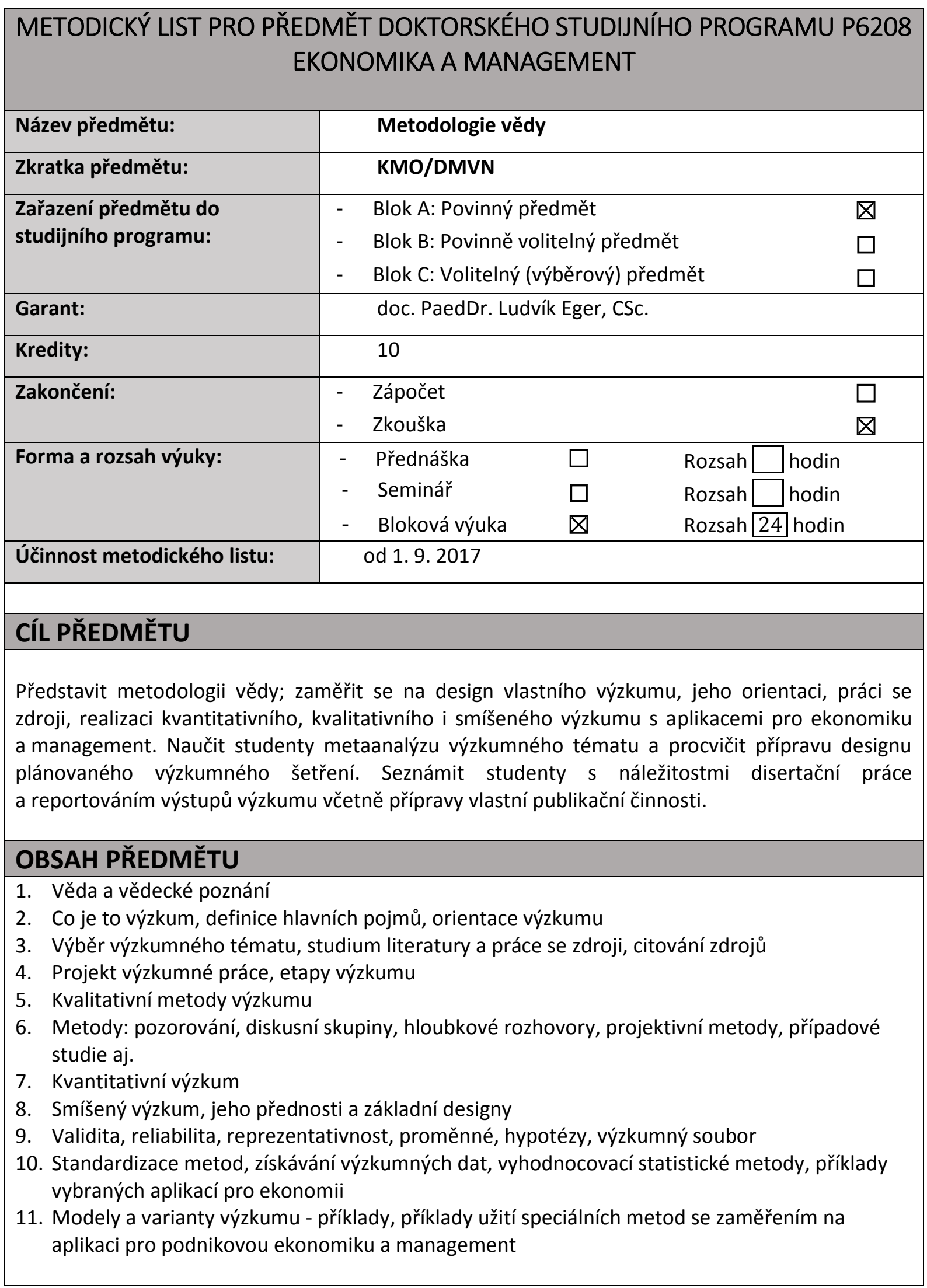


12. Seznámení s náležitostmi disertační práce dle norem a dle pokynů FEK ZČU v PIzni, publikační činnost - ukázky a doporučení

\section{OBSAH PŘEDMĚTU S DALŠÍ SPECIFIKACÍ}

1. Věda a vědecké poznání

a) Vývoj vědy

b) Metodologie vědy

c) Členění výzkumu

d) GAČR, TAČR, SGS, smluvní výzkum aj.

Klíčová slova:

věda, metodologie vědy, základní výzkum, aplikovaný výzkum, agentury pro podporu výzkumu

2. Co je to výzkum, definice hlavních pojmů, orientace výzkumu
a) Deskriptivní výzkum
b) Explorační výzkum
c) Explanační výzkum
d) Etika výzkumu

Klíčová slova:

zaměření výzkumu, deskriptivní, explorační, explanační, evaluační, etika výzkumu

3. Výběr výzkumného tématu, studium literatury a práce se zdroji, citování zdrojů

a) Výzkumná oblast a výzkumné téma

b) Zdroje vědecké literatury, odborné databáze podniků apod.

c) Citační normy

d) Zpracování systematického přehledu literatury

Klíčová slova:

výzkumné téma, vědecké zdroje, WoS, Scopus, metaanalýza

4. Projekt výzkumné práce, etapy výzkumu

a) Výběr designu výzkumu a strategie výzkumu

b) Klasické schéma výzkumu dle Punche

c) Základní etapy výzkumu

Klíčová slova:

strategie výzkumu, design výzkumu, etapy výzkumu

5. Kvalitativní metody výzkumu
a) Narativní výzkum
b) Fenomenologie
c) Etnografie
d) Zakotvená teorie
e) Př́padové studie
f) Akční výzkum
g) Historický výzkum

Klíčová slova:

rozvoj kvalitativního výzkumu, strategie kvalitativního výzkumu 
6. Metody: pozorování, diskusní skupiny, hloubkové rozhovory, projektivní metody, prípadové studie aj.

a) Pozorování a jeho varianty

b) Focus group

c) Hloubkové rozhovory

d) Kvalitativní výzkum a prostředí internetu

e) Dotazování, dotazník, standardizace dotazníku

\section{Klíčová slova:}

pozorování, focus group, hloubkové rozhovory, dotazování

7. Kvantitativní výzkum

a) Experimentální a neexperimentální výzkum

b) Experimenty a kvaziexperimenty

c) Kvantitativní výzkumná šetření

d) Sociální výzkum a aplikace statistických metod

Klíčová slova:

experiment, kvantitativní šetření, statistika v aplikacích

8. Smíšený výzkum, jeho přednosti a základní designy

a) Souběžný paralerní design

b) Explanační sekvenční design

c) Explorativní sekvenční design

d) Vložený design

\section{Klíčová slova:}

smíšený výzkum, základní formy smíšeného výzkumu, doporučený postup

9. Validita, reliabilita, reprezentativnost, proměnné, hypotézy, výzkumný soubor

a) Validita a reliabilita výzkumu

b) Výzkumný soubor a reprezentativnost vzorku

c) Operacionalizace proměnných a hypotézy

d) Popisná statistická analýza

\section{Klíčová slova:}

validita, reliabilita, výzkumný soubor, proměnná, hypotéza, deskriptivní statistika

10. Standardizace metod, získávání výzkumných dat, vyhodnocovací statistické metody, príklady vybraných aplikací pro ekonomii

a) Př́klady standardizace metod a nástrojů ve výzkumu

b) Statistická analýza, přehled složitějších postupů

Klíčová slova:

pilotáž, předvýzkum, standardizace dotazníku, statistika v aplikacích

11. Modely a varianty výzkumu - př́klady, příklady užití speciálních metod se zaměřením na aplikaci pro podnikovou ekonomiku a management

a) Př́klady aplikací dvourozměrné analýzy (Hendl a Remr)

b) Př́klady aplikací vícerozměrné analýzy, ukázky vědeckých výstupů

Klíčová slova:

statistická analýza, aplikace pro ekonomy 
12. Seznámení s náležitostmi disertační práce dle norem a dle pokynů FEK ZČU v Plzni, publikační činnost - ukázky a doporučení

a) Náležitosti disertační práce

b) Disertační práce a "disertabilita"

c) Struktura vědeckého článku

d) Zkušenosti s revizí a úpravami vědeckých článků

\section{Klíčová slova:}

disertační práce, abstrakt, teoretický vstup, metodologie, prezentace výstupů, diskuse, omezení výzkumu

\section{LITERATURA}

\section{Základní:}

$\checkmark$ Gray, D. E. (2009). Doing research in the real world. (2 ${ }^{\text {nd }}$ edition). Los Angeles: SAGE.

$\checkmark$ Hendl, J. (2009). Přehled statistických metod: analýza a metaanalýza dat. (3. přepracované vydání). Praha: Portál.

$\checkmark$ Hendl, J. \& Remr, J. (2017). Metody výzkumu a evaluace. Praha: Portál.

$\checkmark$ Saunders, M. \& Lewis, P. (2009). Research methods for business students. (11 ${ }^{\text {th }}$ edition). Harlow: Prentice Hall.

\section{Doporučená:}

$\checkmark$ Creswell, J. W. (2009). Research design: Qualitative, Quantitative, and Mixed Methods Approaches. ( $3^{\text {rd }}$ edition). Thousand Oaks: SAGE.

$\checkmark$ Punch, K. (2008). Úspěšný návrh výzkumu. (1. vydání). Praha: Portál.

$\checkmark \quad$ Eger, L. \& Egerová, D. (2014). Základy metodologie výzkumu: pro studenty ekonomických oborů. (1. vydání). Plzeň: ZČU v Plzni.

$\checkmark$ Myers, J. L., Well, A.D. \& Lorch Jr. R.F. (2010). Research design and statistical analysis. ( $3^{\text {rd }}$ edition). London: Routledge.

$\checkmark \quad$ Hendl, J. \& kol. (2014). Statistika v aplikacích. Praha: Portál.

$\checkmark$ Hebák P. \& kol. (2013). Statistické myšlení a nástroje analýzy dat. (1. vydání). Praha: Informatorium.

\section{POŽADAVKY NA STUDENTA}

1. Zvládnout předmět $v$ rozsahu stanoveném sylabem a prokázat vědomosti a dovednosti z metodologie výzkumu při ústní zkoušce, která je spojena s obhajobou semestrální práce.

2. Aktivní účast minimálně na třech workshopech (blocích výuky), samostudium doporučených zdrojů.

3. Rozpracování teoretické části práce zhodnocením relevantních zdrojů z vědeckých časopisů formou strukturované metaanalýzy a prezentování výstupu na semináři.

4. Zpracování semestrální práce: design výzkumu vlastní disertační práce. Student ji odevzdá po konzultaci se svým školitelem (rozsah práce je 20 - 25 normostran).

5. Zkouška je formou obhajoby semestrální práce. 


\section{FORMA A ROZSAH VÝUKY}

Výuka předmětu probíhá formou blokové prezenční výuky (24 hodin) a individuálních konzultací s garantem predmětu.

1. Obsah 1. výukového bloku, rozsah 6 hodin

a) Úvod do metodologie vědy

b) Tři paradigmata a strategie výzkumu

c) Tři hlavní účely výzkumu

d) Oblast výzkumu, téma, výzkumné otázky

e) Publikování výsledků vědeckého výzkumu

f) Etika

2. Obsah 2. výukového bloku, rozsah 6 hodin

a) Vědecké databáze a práce se zdroji, seminář v knihovně univerzity

b) Metaanalýza, teorie, ukázky

c) Skupinová práce dle zaměření studentů, příprava metaanalýzy

d) Realizace metaanalýzy ( 2 hod. cvičení s využitím PC a softwaru), príprava malé prezentace

e) Ukázka výstupu a diskuse

3. Obsah 3. výukového bloku, rozsah 6 hodin

a) Výběr z kvalitativních metod (Focus group, hloubkový rozhovor, analýza textu)

b) Dotazování a dotazník, vytváření dotazníku, administrace, vyhodnocování

c) Evaluační výzkum a predikce, Delphi metoda

d) Př́klady aplikací výzkumných metod pro kvalitativní, kvantitativní i smíšený výzkum

e) Diskuse k designům výzkumu

4. Obsah 4. výukového bloku, rozsah 6 hodin

a) Design výzkumu

b) Prezentace výzkumu, výzkumná zpráva, príprava na konferenci

c) Příprava námětu designu vlastního výzkumu ve vztahu k disertační práci (1hod.)

d) Prezentace prvního návrhu před skupinou

\section{DALŠÍ INFORMACE GARANTA PŘEDMĚTU}

Seminární práci zaměřenou na design výzkumu ve vztahu k plánované disertační práci doktorand nejdřive představí svému školiteli, teprve potom ji odevzdá na posouzení v rámci předmětu.

\section{KONTAKT NA GARANTA PŘEDMĚTU}

\begin{tabular}{|l|l|}
\hline E-mail: & leger@kmo.zcu.cz \\
\hline Telefon: & +420377633312 \\
\hline Konzultační hodiny: & (dle aktuálního zadání na www.fek.zcu.cz) \\
\hline Kancelář: & UK 518 , FEK ZČU, Univerzitní 22, 306 14 Plzeň \\
\hline
\end{tabular}




\section{Řízení podnikových procesů}

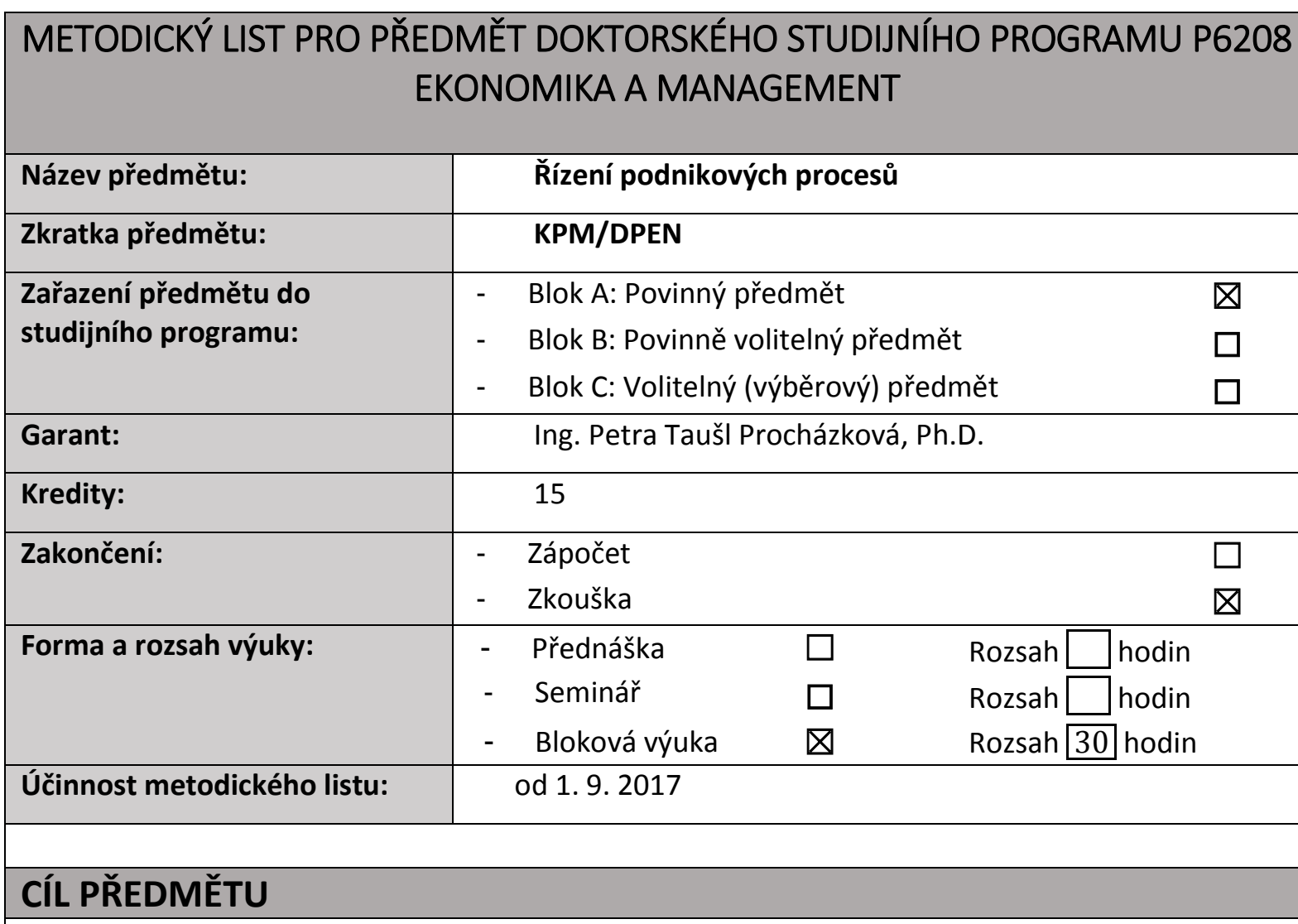

Poskytnout na pokročilejší úrovni systematický přehled o fungování podniku, podnikových procesech, a to i v kontextu globální a znalostní ekonomiky. Seznámit se s moderními prístupy podnikové ekonomiky a managementu.

\section{OBSAH PŘEDMĚTU}

1. Analýza a optimalizace podnikových procesů

2. Podnikatelské prostředí, podnikání, vnější vlivy na podnik

3. Podnikohospodářské modely

4. Specifika různých typů organizací

5. Moderní trendy v podnikové ekonomice a rízení podniků (organizací)

\section{OBSAH PŘEDMĚTU S DALŠÍ SPECIFIKACÍ}

1. Analýza a optimalizace podnikových procesů

a) Metody analýzy podnikových procesů

b) Metody a nástroje pro optimalizace a racionalizaci podnikových procesů

Klíčová slova:

optimalizace, podnikový proces, racionalizace, six sigma, TOC, VSM, 5S 
2. Podnikatelské prostředí, podnikání, vnější vlivy na podnik

a) Podnikatelské prostředí a jeho vliv na podnik

b) Specifika různých forem v podnikání v novém prostředí

c) Vnější vlivy na podnik reflektující současný vývoj podnikohospodářského prostředí

Klíčová slova:

IOT, Industry 4.0, prostředí

3. Podnikohospodářské modely

a) Podnikání, podnik v globální a znalostní ekonomice

b) Finanční a nefinanční ukazatele hodnocení podniku

Klíčová slova:

KPI, KRI, znalostní ekonomika

4. Specifika různých typů organizací

a) Neziskové organizace

b) Státní správa

c) Specifika spolupráce s těmito organizacemi

Klíčová slova:

NGO, výběrové rízení

5. Moderní trendy v podnikové ekonomice a řízení podniků (organizací)

a) Moderní prístupy k managementu

b) Udržitelnost

c) Společenská odpovědnost

d) Moderní přístupy k projektovému rrízení

Klíčová slova:

agile, CSR, sustainability, scrum

\section{LITERATURA}

Základní:

$\checkmark$ Halevi, G. (2001). Handbook of production management methods (1. vydání). Oxford: Butterworth-Heinemann.

$\checkmark$ Rother, M. \& Shook, J. (2003). Learning to see: value-stream mapping to create value and eliminate muda (1. vydání). Cambridge: Lean Enterprise Institute.

$\checkmark$ Kislingerová, E. \& kol. (2011). Nová ekonomika: nové príležitosti? (1. vydání). Praha: C.H. Beck.

$\checkmark$ Jones, P. \& Robinson, P. (2012). Operations Management (1. vydání). Oxford: Oxford University Press.

\section{Doporučená:}

Manfred P. \& Tolhurst, N. (2010). Responsible Business: How to manage a CSR strategy successfully (1. vydání). Chichester: Wiley. 


\section{POŽADAVKY NA STUDENTA}

1. Aktivní účast na čtyřech blocích výuky, samostudium doporučených zdrojů.

2. Zpracování seminární práce(í) dle zadání.

3. Zpracování a obhajoba obsahu vědeckého článku.

4. Zkouška je formou obhajoby uvedené semestrální práce(í) s diskusí k otázkám, které souvisejí $s$ tématem této práce.

\section{FORMA A ROZSAH VÝUKY}

Výuka předmětu probíhá formou blokové prezenční výuky (30 hodin) a individuálních konzultací s garantem predmětu.

1. Obsah 1. výukového bloku, rozsah 7 hodin

a) Úvodní seznámení s obsahem předmětu a seznámení s podmínkami splnění předmětu

b) Zadání okruhů k samostudiu, diskuse nad okruhy

c) Zadání seminárních prací, diskuse nad zadáním

d) Zadání dílčího problému $\mathrm{k}$ řešení ve formě vědeckého článku, diskuse $k$ dílčím problémům

2. Obsah 2. výukového bloku, rozsah 8 hodin - Analýza a optimalizace podnikových procesů

a) Metody analýzy podnikových procesů

b) Metody a nástroje pro optimalizace a racionalizaci podnikových procesů

c) Prezentace a diskuse seminárních prací a zadaných úkolů k samostudiu

3. Obsah 3. výukového bloku, rozsah 7 hodin - Podnikohospodářské modely

a) Podnikání, podnik v globální a znalostní ekonomice

b) Finanční a nefinanční ukazatele hodnocení podniku

c) Prezentace a diskuse seminárních prací a zadaných úkolů k samostudiu

4. Obsah 4. výukového bloku, rozsah 8 hodin - Moderní trendy v podnikové ekonomice a řízení podniků (organizací)

a) Specifika jiných typů organizací

b) Moderní prístupy k managementu

c) Prezentace a diskuse seminárních prací a zadaných úkolů k samostudiu

\section{DALŠÍ INFORMACE GARANTA PŘEDMĚTU}

\section{KONTAKT NA GARANTA PŘEDMĚTU}

\begin{tabular}{|l|l|}
\hline E-mail: & pprochaz@kpm.zcu.cz \\
\hline Telefon: & +420377633618 \\
\hline Konzultační hodiny: & (dle aktuálního zadání na www.fek.zcu.cz) \\
\hline Kancelář: & UK 416, FEK ZČU, Univerzitní 22, 306 14 Plzeň \\
\hline
\end{tabular}


Kompetence $v$ akademickém odborném jazyce

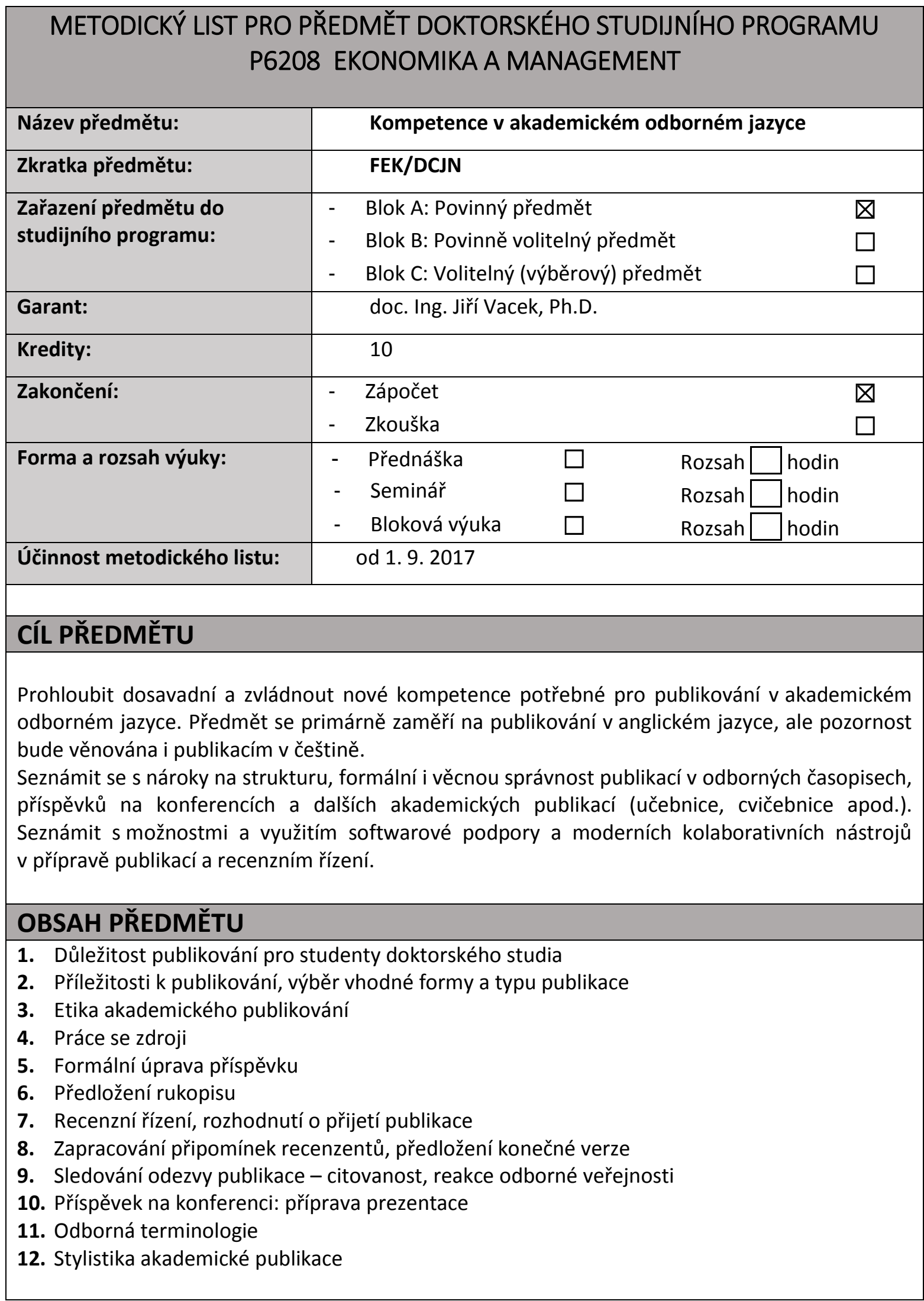




\section{OBSAH PŘEDMĚTU S DALŠÍ SPECIFIKACÍ}

\section{LITERATURA}

\section{Základní:}

Doing a PhD: Why it's important to publish. (nedatováno). Dostupné z:

https://www.postgrad.com/advice/phd/why_its_important_to_publish/

$\checkmark$ Graduate Student Guide to Publishing Your Research. (nedatováno).

Knihovna ZČU. (2017). Dostupné z: knihovna.zcu.cz

$\checkmark$ Meško, D., Dušan, K., Findra, J. \& kol. (2013). Akademická príručka. Martin: Osveta.

$\checkmark$ Morisano, D., Winstanley, E. L., Morojele, N. \& Babor, T. F. (2017). Getting Started:

Publication Issues for Graduate Students, Postdoctoral Fellows, and other Aspiring Addiction

Scientists. V T. F. Babor, Publishing Addiction Science: A Guide for the Perplexed (stránky 89-

118). London: Ubiquity Press. doi:DOI: https://doi.org/10.5334/bbd.e

$\checkmark$ Palenčárová, J. \& Kročitý, P. (2011). Akademická príručka k tvorbe odborných textov.

Dostupné z: http://www.vsm.sk/files/sh/priruckahotovo2.pdf

$\checkmark$ Stoilescu, D. \& McDougall, D. (2010). Starting to Publish Academic Research as a Doctoral Student. International Journal of Doctoral Studies, 5, stránky 79 - 92. Dostupné z: http://ijds.org/Volume5/IJDSv5p079-092Stoilescu299.pdf

\section{Doporučená:}

Aktuální literatura podle doporučení garanta předmětu, články z časopisů, příspěvky na konferencích

\section{POŽADAVKY NA STUDENTA}

1. Vstupní požadavky na studenta:

a) Zvládat gramatiku a stylistiku jazyka (čeština - na úrovni maturitní zkoušky, cizí jazyk úroveň B2).

b) Zvládat funkce textového editoru MS Word (formátování dokumentu a práce se styly, karty Revize, Reference).

c) Orientovat se v knihovních databázích.

2. Pro absolvování předmětu se požaduje se, aby student měl znalost alespoň jednoho světového jazyka. Dává se přednost anglickému jazyku, ale ve zdůvodněných př́padech je možno uznat i znalost německého, francouzského nebo ruského jazyka.

3. Student znalost prokazuje jedním z následujících způsobů:

a) doktorand publikuje cizojazyčný př́spěvek, se kterým aktivně vystoupí na odborné konferenci; př́spěvek předloží $\mathrm{k}$ posouzení školitele a doloženou žádost o uznání cizího jazyka předloží na studijní oddělení pro DSP. O uznání rozhodne garant předmětu FEK/DCJN; b) doktorand připraví a vede minimálně jednu odbornou přednášku v cizím jazyce; přednášku posoudí školitel a na základě doložené žádosti o uznání rozhodne garant předmětu FEK/DCJN;

c) doktorand absolvuje minimálně měsiční odbornou stáž v zahraničí. O uznání rozhodne garant předmětu FEK/DCJN;

d) doktorand má doklad o jazykové způsobilosti. Informace, jaké doklady se uznávají, poskytne studijní oddělení pro DSP. O uznání rozhodne garant předmětu FEK/DCJN;

e) doktorand složí zkoušku ze zvoleného jazyka na odborné úrovni na ÚJP ZČU. Realizaci této formy předem nahlásí na studijní oddělení pro DSP. Požadavky na zkoušku stanoví ÚJP v součinnosti se školitelem a garantem předmětu FEK/DCJN, který následně rozhodne o uznání předmětu. 


\section{FORMA A ROZSAH VÝUKY}

Výuka předmětu probíhá formou individuálních konzultací s garantem předmětu.

\section{DALŠÍ INFORMACE GARANTA PŘEDMĚTU}

\section{KONTAKT NA GARANTA PŘEDMĚTU}

\begin{tabular}{|l|l|}
\hline E-mail: & vacekj@kpm.zcu.cz \\
\hline Telefon: & +420377633007 \\
\hline $\begin{array}{l}\text { Konzultační } \\
\text { hodiny: }\end{array}$ & (dle aktuálního zadání na www.fek.zcu.cz) \\
\hline Kancelář: & UK 420, FEK ZČU, Univerzitní 22, 306 14 Plzeň \\
\hline
\end{tabular}


Řízení lidských zdrojů

\begin{tabular}{|c|c|c|c|c|}
\hline \multicolumn{5}{|c|}{$\begin{array}{r}\text { METODICKÝ LIST PRO PŘEDMĚT DOKTORSKÉHO STUDIJN } \\
\text { EKONOMIKA A MANAGEMENT }\end{array}$} \\
\hline Název předmětu: & \multicolumn{4}{|c|}{ Řízení lidských zdrojů } \\
\hline Zkratka předmětu: & \multicolumn{4}{|l|}{ KPM/DRLZN } \\
\hline $\begin{array}{l}\text { Zařazení předmětu do } \\
\text { studijního programu: }\end{array}$ & \multicolumn{3}{|c|}{$\begin{array}{l}\text { Blok A: Povinný předmět } \\
\text { Blok B: Povinně volitelný předmět } \\
\text { Blok C: Volitelný (výběrový) předmět }\end{array}$} & $\begin{array}{l}\square \\
\square \\
\square\end{array}$ \\
\hline Garant: & \multicolumn{4}{|c|}{ doc. PaedDr. Dana Egerová, Ph.D. } \\
\hline Kredity: & \multicolumn{4}{|l|}{15} \\
\hline Zakončení: & $\begin{array}{ll}\text { - } & \text { Zápočet } \\
\text { - } & \text { Zkouška }\end{array}$ & & & $\begin{array}{l}\square \\
\square\end{array}$ \\
\hline Forma a rozsah výuky: & $\begin{array}{ll}\text { - } & \text { Přednáška } \\
\text { - } & \text { Seminář } \\
\text { - } & \text { Bloková výuka }\end{array}$ & $\begin{array}{l}\square \\
\square \\
\square\end{array}$ & $\begin{array}{l}\text { Rozsah } \square \text { hodin } \\
\text { Rozsah } \square \text { hodin } \\
\text { Rozsah } 30 \text { hodin }\end{array}$ & \\
\hline Účinnost metodického listu: & od 1. 9. 2017 & & & \\
\hline
\end{tabular}

Cílem předmětu je poskytnout nejnovější vědecké poznatky z vybraných oblastí řízení lidských zdrojů, diskutovat současné empirické i teoretické výzkumy $v$ dané oblasti a seznámit se současnými aktuálními trendy voblasti řízení lidských zdrojů. Cílem předmětu je rovněž prohloubení znalostí idovedností studentů nezbytných $k$ řešení konkrétních výzkumných problémů ŕízení lidských zdrojů v současné organizaci, a to jak na lokální, tak i globální úrovni.

\section{OBSAH PŘEDMĚTU}

1. Řízení lidských zdrojů

2. Strategické řízení lidských zdrojů

3. Architektura řízení lidských zdrojů v organizaci

4. Řízení pracovního výkonu a odměňování

5. Řízení lidského kapitálu

6. Personální controlling

7. Personální marketing

8. Ǩízení lidských zdrojů v podmínkách globalizovaného světa

9. Aktuální trendy v oblasti řizení lidských zdrojů

10. Výzkum v oblasti řízení lidských zdrojů 
1. Řízení lidských zdrojů - cíle, vymezení

a) Koncepce řízení lidských zdrojů

b) Teorie ř́zení lidských zdrojů

c) Modely řízení lidských zdrojů

\section{Klíčová slova:}

vývojové etapy, teorie založená na zdrojích, kontingenční teorie, teorie AMO, měkké přístupy, tvrdé prístupy, modely

2. Strategické řízení lidských zdrojů (SŘLZ)
a) Podstata a cíle SŘLZ
b) Pojetí SŘLZ
c) Rámec SŘLZ

\section{Klíčová slova:}

strategické ř́zení, základní přístupy, obecná strategie LZ, specifická strategie LZ, aktivity SŘLZ

3. Architektura řizení lidských zdrojů v organizaci

a) Role a význam personalistů a personálních útvarů v organizaci

b) Politiky lidských zdrojů

c) Činnosti řízení lidských zdrojů

Klíčová slova:

strategický business partner, role dle Ulricha, transformační činnosti, transakční činnosti

4. Řízení pracovního výkonu a odměňování

a) Východiska a cíle řízení pracovního výkonu

b) Cyklus řízení pracovního výkonu

c) Strategie a systém odměňování

Klíčová slova:

pracovní výkon, matice pracovního výkonu, 360 stupňová zpětná vazba, hodnocení práce, peněžní a nepeněžní odměny

5. Řízení lidského kapitálu

a) Pojetí lidského kapitálu

b) Podstata řizení lidského kapitálu

c) Měření lidského kapitálu

Klíčová slova:

lidský kapitál, intelektuální kapitál, společenský kapitál, organizační kapitál, index lidského kapitálu, ukazatele měření lidského kapitálu

6. Personální controlling

a) Cíle a přínosy personálního controllingu

b) Operativní a strategický controlling

c) Kvantitativní a kvalitativní personální controlling

d) Nástroje personálního controllingu

Klíčová slova:

personální ukazatele, personální reporting, nástroje kvalitativního controllingu, personální standardy, personální audit 
7. Personální marketing a značka zaměstnavatele

a) Cíle a význam pro organizaci

b) Externí personální marketing

c) Interní personální marketing

d) Employer branding - budování a řízení značky zaměstnavatele

\section{Klíčová slova:}

interní marketing a angažovanost, firemní kultura, image, employement value preposition (EVP), získávání, sociální média, metriky

8. Ǩízení lidských zdrojů v podmínkách globalizovaného světa

a) Specifika mezinárodního řízení lidských zdrojů

b) Přístupy k mezinárodnímu řízení lidských zdrojů

c) Řízení expatriantů

Klíčová slova:

kulturní odlišnosti, globální trendy, Pelrmutterova typologie přístupů, proces expatriace

9. Trendy v oblasti ř́zení lidských zdrojů (vybraná témata)

a) Talent management

b) Diversity management

c) Age management

\section{Klíčová slova:}

exklusivní přistup, inklusivní př́stup, integrovaný talent management, primární diversita, sekundární diversita, metriky

10. Výzkum v oblasti řízení lidských zdrojů
a) Oblasti výzkumu
b) Používané metody
c) Plánování a realizace výzkumného projektu

\section{Klíčová slova:}

design výzkumného projektu, kvalitativní a kvantitativní metody

\section{LITERATURA}

Základní:

$\checkmark$ Armstrong, M. \& Taylor, S. (2015). Řizení lidských zdrojů: moderní pojetí a postupy. (13. vydání). Praha: Grada.

$\checkmark$ Dessler, G. (2015) Human resource management. (14 ${ }^{\text {th }}$ edition). Boston: Pearson.

$\checkmark$ Markoulli, M., Lee, C., Byington, E. \& Felps, W. A. (2017). Mapping Human Resource Management: Reviewing the field and charting future directions. Human Resource Management Review. 27(3), p. 367-396.

$\checkmark$ Noe, R. A., Hollenbeck, J. R., Gerhart, B. A. \& Wright, P. M. (2015). Human resource management: gaining a competitive advantage. Berkshire: McGraw-Hill.

\section{Doporučená:}

$\checkmark \quad$ Bláha, J. \& kol. (2013). Pokročilé rízení lidských zdrojů. Brno: Edika.

$\checkmark$ Dvořáková, Z. (2012). Řízení lidských zdrojů. Praha: C. H. Beck.

$\checkmark$ Egerová, D. \& kol. (2013). Integrated talent management: challenge and future for organizations in Visegrad countries. Plzeň: Nava.

$\checkmark$ Mosley, R. \& Schmidt, L. (2017). Employer branding. Hoboken: John Wiley \& Sons.

$\checkmark$ Ulrich, D. (2009). Mistrovské rízení lidských zdrojü. (1. české vydání). Praha: Grada. 
+ doporučené odborné články

\section{POŽADAVKY NA STUDENTA}

1. Aktivně se účastnit seminárứ, zapojovat se do diskusí k prezentovaným tématům a samostatně nastudovaným doporučeným zdrojům.

2. Zpracovat a prezentovat kritická zhodnocení 3 odborných článků primárně zaměřených na témata obsažená v sylabu předmětu v rozsahu 4 až 7 normostran. Články budou vybrány z časopisů evidovaných $v$ databázích Web of Science nebo Scopus. Kritéria pro zpracování hodnocení budou upřesněna na úvodním semináři.

3. Zpracovat a odevzdat odborný článek na vybrané téma z oblasti řízení lidských zdrojů. Struktura článku by měla odpovídat struktuře vědeckého článku publikovaného v oborném časopise. Zvolené téma je potřebné konzultovat s garantem předmětu. Rozsah článku minimálně $15-20$ stránek. Článek bude rovněž prezentován formou odborné prezentace na závěrečném semináři.

4. Prokázat získané znalosti, vědomosti a dovednosti při ústní zkoušce, jejíz obsahem bude rozprava nad odborným článkem a diskuse k tématům stanovených sylabem předmětu.

\section{FORMA A ROZSAH VÝUKY}

Výuka předmětu probíhá formou blokové prezenční výuky (30 hodin) a individuálních konzultací s garantem predmětu.

1. Obsah 1. výukového bloku, rozsah 6 hodin

a) Seznámení s obsahem a filozofií předmětu, upřesnění požadavků na jeho absolvování

b) Koncepce personálního řízení a řízení lidských zdrojů - vývoj

c) Teoretické modely v řízení lidských zdrojů

d) Úvod do strategického řízení lidských zdrojů

2. Obsah 2. výukového bloku, rozsah 6 hodin

a) Výzkum v oblasti ř́zení lidských zdrojů

b) Role výzkumu v dané oblasti

c) Aktuální a budoucí trendy a témata

d) Používané výzkumné metody a techniky

Doporučená literatura jako výchozí bod diskuse $\mathrm{k}$ danému tématu:

$\checkmark$ Markoulli, M., Lee, C., Byington, E. \& Felps, W.A. (2017). Mapping Human Resource Management: Reviewing the field and charting future directions. Human Resource Management Review. 27(3), p .367-396.

3. Obsah 3. výukového bloku, rozsah 6 hodin

a) Intelektuální kapitál - vymezení, členění

b) Model řizení intelektuálního kapitálu

c) Měření výkonnosti lidského kapitálů - ukazatele

d) Prezentace zpracovaných kritických rešerší vybraných odborných článků a následná diskuse. 
4. Obsah 4. výukového bloku, rozsah 6 hodin

a) Řízení pracovního výkonu - východiska a cíle

b) Nástroje k řízení pracovního výkonu

c) Vytváření a zavádění strategie odměňování

d) Prezentace zpracovaných kritických rešerší vybraných odborných článků a následná diskuse.

5. Obsah 5. výukového bloku, rozsah 6 hodin

a) Závěrečné odborné prezentace zpracovaných odborných článků na zvolené téma s následnou diskusí - viz požadavky na studenty

\section{DALŠÍ INFORMACE GARANTA PŘEDMĚTU}

Na úvodním semináři budou specifikovány formální i obsahové požadavky na kritická zhodnocení vybraných odborných článků i na zpracování odborného článku.

\section{KONTAKT NA GARANTA PŘEDMĚTU}

\begin{tabular}{|l|l|}
\hline E-mail: & egerova@kpm.zcu.cz \\
\hline Telefon: & +420377633600 \\
\hline Konzultační hodiny: & (dle aktuálního zadání na www.fek.zcu.cz) \\
\hline Kanceláŕ: & UK 414, FEK ZČU, Univerzitní 22, 306 14 Plzeň \\
\hline
\end{tabular}


Kolokvium

\section{METODICKÝ LIST PRO PŘEDMĚT DOKTORSKÉHO STUDIJNÍHO PROGRAMU P6208 EKONOMIKA A MANAGEMENT}

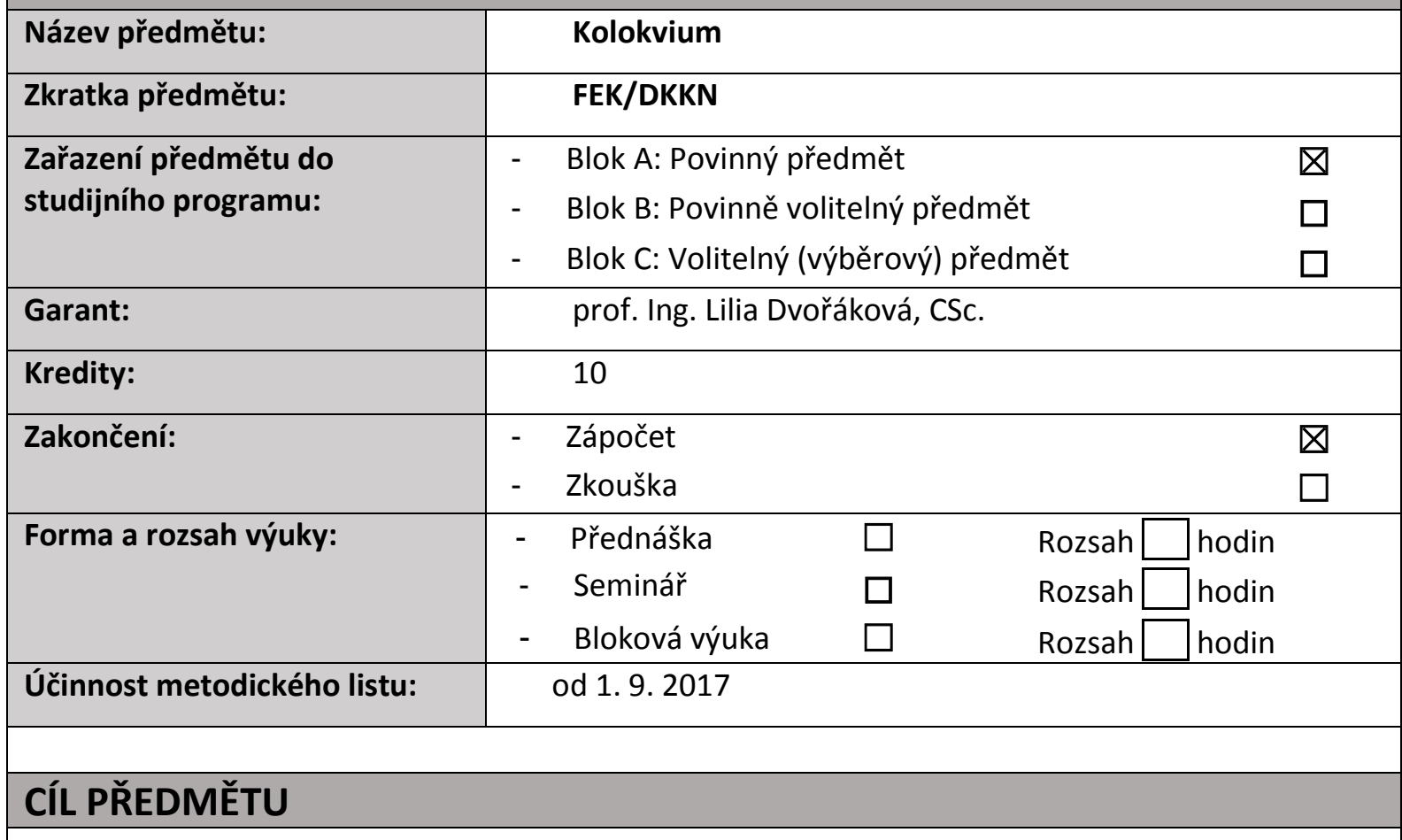

Ověřit cíle, metody a výsledky rozpracovaného tématu disertační práce v rozsahu písemné výzkumné práce ke kolokviu. Prezentovat a diskutovat výsledky písemné práce ke kolokviu $v$ rozsahu písemné práce ke státní doktorské zkoušce. Prezentovat a diskutovat publikační výstupy studenta vztahující se k zaměření doktorské disertační práce. Poskytnout podněty pro úspěšné dokončení písemné práce ke státní doktorské zkoušce a doktorské disertační práce.

\section{OBSAH PŘEDMĚTU}

1. Odborná príprava na kolokvium

2. Zpracování písemné práce ke kolokviu v rozsahu písemné práce ke státní doktorské zkoušce včetně návrhu designu výzkumu, závěrů teoretických rešerší a výsledků vlastní výzkumné činnosti

3. Príprava prezentace na kolokvium

4. Prezentace a obhajoba písemné výzkumné práce ke kolokviu před členy katedry a odbornou veřejností

5. Rozprava k cílům, metodologii a výsledkům výzkumné činnosti doktoranda

\section{OBSAH PŘEDMĚTU S DALŠí SPECIFIKACÍ}

Obsahová př́prava na předmět a na jeho zakončení zápočtem se realizuje ve spolupráci se školitelem doktoranda. 


\section{LITERATURA}

\section{Základní:}

Literární a ostatní zdroje dle obsahového zaměření tématu doktorské disertační práce a písemné práce ke státní doktorské zkoušce.

\section{Doporučená:}

$\checkmark \quad$ Literární a ostatní zdroje dle obsahového zaměření tématu doktorské disertační práce a písemné práce ke státní doktorské zkoušce.

\section{POŽADAVKY NA STUDENTA}

1. Kolokvium Ize realizovat, když má student splněny všechny dílčí zkoušky s výjimkou státní doktorské zkoušky.

2. Rozsah písemné výzkumné práce ke kolokviu je minimálně 60 stran standartního textu formátu A4.

3. Vytištěná písemná práce ke kolokviu se odevzdává nejpozději 14 dní před konáním kolokvia školiteli a pracovníkovi pro doktorské studium na FEK.

4. V rámci kolokvia doktorand představí téma disertační práce, cíle a metodologii výzkumu, závěry teoretických rešerší a výsledky výzkumné činnosti v rámci zpracování tématu práce.

5. V rámci kolokvia doktorand vymezí další postup při zpracování doktorské disertační práce a prínosy práce pro rozvoj teorie a praxe v oboru Ekonomika a management.

6. V rámci kolokvia doktorand uvede vlastní publikační aktivity související s tématem doktorské disertační práce.

\section{FORMA A ROZSAH VÝUKY}

Výuka probíhá formou individuálních konzultací se školitelem doktoranda.

\section{DALŠí INFORMACE GARANTA PŘEDMĚTU}

1. Kolokvium svolává na návrh školitele doktoranda vedoucí př́íslušné katedry.

2. Student projedná se svým školitelem a vedoucím příslušné katedry termín konání kolokvia.

3. Školitel ve spolupráci se studentem připraví pozvánku na kolokvium.

4. Školitel předá pozvánku na kolokvium pracovníkovi pro doktorské studium na FEK ZČU a vedoucímu př́slušné katedry.

5. Vedoucí př́slušné katedry zveřejní pozvánku na webových stránkách katedry a formou zaslání pozvánky na děkanát FEK, předsedovi Oborové rady FEK a vedoucím kateder na FEK ZČU nejpozději 14 dní před konáním kolokvia.

6. Pracovník pro doktorské studium na FEK zveřejní pozvánku na webových stránkách fakulty nejpozději 14 dní před konáním kolokvia.

7. Odbornou rozpravu na kolokviu řídí školitel doktoranda.

8. Zápis z kolokvia provede vedoucí katedry nebo pracovník stanovený vedoucím př́slušné katedry.

9. Kontrolu zápisu z kolokvia provede školitel a předá jej pracovníkovi pro doktorské studium na FEK ZČU. 


\section{KONTAKT NA GARANTA PŘEDMĚTU}

\begin{tabular}{|l|l|}
\hline E-mail: & Idvorako@kfu.zcu.cz \\
\hline Telefon: & +420377633207 \\
\hline Konzultační hodiny: & (dle aktuálního zadání na www.fek.zcu.cz) \\
\hline Kancelář: & UK 514, FEK ZČU, Univerzitní 22, 306 14 Plzeň \\
\hline
\end{tabular}


Vědecko-výzkumná činnost 1

\section{METODICKÝ LIST PRO PŘEDMĚT DOKTORSKÉHO STUDIJNÍHO PROGRAMU P6208 EKONOMIKA A MANAGEMENT}

\begin{tabular}{|c|c|c|c|c|c|}
\hline Název předmětu: & \multicolumn{5}{|c|}{ Vědecko-výzkumná činnost 1} \\
\hline Zkratka předmětu: & \multicolumn{5}{|l|}{ FEK/DVVN1 } \\
\hline $\begin{array}{l}\text { Zařazení předmětu do } \\
\text { studijního programu: }\end{array}$ & \multicolumn{3}{|c|}{$\begin{array}{ll}- & \text { Blok A: Povinný předmět } \\
\text { - } & \text { Blok B: Povinně volitelný předmět } \\
\text { - } & \text { Blok C: Volitelný (výběrový) předmět }\end{array}$} & & $\begin{array}{l}\square \\
\square \\
\square\end{array}$ \\
\hline Garant: & \multicolumn{4}{|c|}{ doc. Dr. Ing. Miroslav Plevný } & \\
\hline Kredity: & \multicolumn{4}{|l|}{10} & \\
\hline Zakončení: & \multicolumn{3}{|l|}{$\begin{array}{ll}\text { - } & \text { Zápočet } \\
\text { - } & \text { Zkouška }\end{array}$} & & $\begin{array}{l}\bigotimes \\
\square\end{array}$ \\
\hline Forma a rozsah výuky: & $\begin{array}{ll}\text { - } & \text { Přednáška } \\
\text { - } & \text { Seminář } \\
\text { - } & \text { Bloková výuka }\end{array}$ & $\begin{array}{l}\square \\
\square \\
\square\end{array}$ & $\begin{array}{l}\text { Rozsah [ } \\
\text { Rozsah [ } \\
\text { Rozsah [ }\end{array}$ & $\begin{array}{l}\text { hodin } \\
\text { hodin } \\
\text { hodin }\end{array}$ & \\
\hline Účinnost metodického listu: & \multicolumn{5}{|l|}{ od 1.9. 2017} \\
\hline \multicolumn{6}{|l|}{ CÍL PŘEDMĚTU } \\
\hline $\begin{array}{l}\text { Zahájit samostatnou tvưrčí v } \\
\text { naučit jej zásadám rešeršní p } \\
\text { činnost studenta publikovánír } \\
\text { na vědeckých konferencích. }\end{array}$ & $\begin{array}{l}\text { ou práci studenta; } \\
\text { standardům struk } \\
\text { upů samostatné i k }\end{array}$ & $\begin{array}{l}\text { jej } \\
\text { ěde }\end{array}$ & $\begin{array}{l}\text { a odb } \\
\text { blikací; } \\
\text { nosti v }\end{array}$ & $\begin{array}{l}\text { h kol } \\
\text { jit pu } \\
\text { ně př }\end{array}$ & \\
\hline
\end{tabular}

\section{OBSAH PŘEDMĚTU}

1. Samostatná tvưrčí vědecká práce studenta pod vedením školitele

2. Účast na odborných seminářích a kolokviích

3. Příprava publikačních výstupů ve vztahu ke studovanému oboru a tématu disertační práce ve formě př́ispěvku na konferenci či článku v odborném časopise

\section{OBSAH PŘEDMĚTU S DALŠÍ SPECIFIKACÍ}

1. Seznámení se $s$ dostupnými publikačními databázemi a zvládnutí základní práce s nimi.

2. Základy rešeršní práce $v$ oblasti tematického zaměření oboru disertační práce.

3. Podíl na řešení konkrétního výzkumného problému.

4. Standardní struktura a náležitosti odborného příspěvku.

5. Citační styly.

6. Recenzní řízení a jeho možné výsledky.

7. Příprava konferenčního vystoupení s prezentací príspěvku.

8. Vykázání publikačního výsledku v evidenční databázi publikací OBD. 


\section{LITERATURA}

$\checkmark$ dle pokynů školitele

\section{POŽADAVKY NA STUDENTA}

1. Př́íprava vědeckého výstupu ve vztahu ke studovanému oboru.

2. Úspěšné publikování vědeckého příspěvku minimálně v jedné z následujících forem:

a) odborný článek v recenzovaném neindexovaném odborném časopise se zaměřením k oboru studia;

b) příspěvek v neindexovaném sborníku z mezinárodní konference včetně aktivní účasti na této konferenci.

\section{FORMA A ROZSAH VÝUKY}

Výuka předmětu probíhá formou individuálních konzultací se školitelem, speciálních seminářu organizovaných pro doktorandy, účastí na odborných kolokviích a samostatnou prací studenta pod vedením školitele.

\section{DALŠÍ INFORMACE GARANTA PŘEDMĚTU}

Podmínkou získání zápočtu je zanesení publikačního výstupu do univerzitní databáze výsledků ZČU (OBD) minimálně ve stavu „Ke kontrole“.

\section{KONTAKT NA GARANTA PŘEDMĚTU}

\begin{tabular}{|l|l|}
\hline E-mail: & plevny@kem.zcu.cz \\
\hline Telefon: & +420377633501 \\
\hline Konzultační hodiny: & (dle aktuálního zadání na www.fek.zcu.cz) \\
\hline Kancelář: & UL 403, Univerzitní 22, 306 14 Plzeň \\
& $\mathrm{CD} 301$, Hradební 22, Cheb \\
\hline
\end{tabular}


Vědecko-výzkumná činnost 2

\begin{tabular}{|c|c|c|c|c|c|}
\hline \multicolumn{6}{|c|}{$\begin{array}{r}\text { METODICKÝ LIST PRO PŘEDMĚT DOKTORSKÉHO STUDIJNÍ| } \\
\text { - EKONOMIKA A MANAGEMENT }\end{array}$} \\
\hline Název předmětu: & \multicolumn{5}{|c|}{ Vědecko-výzkumná činnost 2} \\
\hline Zkratka předmětu: & \multicolumn{5}{|l|}{ FEK/DVVN2 } \\
\hline $\begin{array}{l}\text { Zařazení předmětu do } \\
\text { studijního programu: }\end{array}$ & \multicolumn{3}{|c|}{$\begin{array}{ll}\text { - } & \text { Blok A: Povinný předmět } \\
\text { - } & \text { Blok B: Povinně volitelný předmět } \\
\text { - } & \text { Blok C: Volitelný (výběrový) předmět }\end{array}$} & & $\begin{array}{l}\bigotimes \\
\square \\
\square\end{array}$ \\
\hline Garant: & \multicolumn{3}{|c|}{ doc. Dr. Ing. Miroslav Plevný } & & \\
\hline Kredity: & \multicolumn{3}{|l|}{15} & & \\
\hline Zakončení: & $\begin{array}{ll}- & \text { Zápočet } \\
\text { - } & \text { Zkouška }\end{array}$ & & & & $\begin{array}{l}\square \\
\square\end{array}$ \\
\hline Forma a rozsah výuky: & $\begin{array}{ll}\text { - } & \text { Přednáška } \\
\text { - } & \text { Seminář } \\
\text { - } & \text { Bloková výuka }\end{array}$ & $\begin{array}{l}\square \\
\square \\
\square\end{array}$ & $\begin{array}{l}\text { Rozsah } \\
\text { Rozsah } \\
\text { Rozsah }\end{array}$ & $\begin{array}{l}\text { hodin } \\
\text { hodin } \\
\text { hodin }\end{array}$ & \\
\hline Účinnost metodického listu: & od 1. 9. 2017 & & & & \\
\hline
\end{tabular}

Vést a podporovat studenta $v$ samostatné tvưrčí vědecké práci; zapojit jej do organizování odborných kolokvií a konferencí; naučit jej publikovat výstupy samostatné i kolektivní tvůrčí činnosti ve formě samostatných kapitol $\mathrm{v}$ monografiích a odborných vědeckých článků $\mathrm{v}$ recenzovaných časopisech, a to primárně v oblasti tematického zaměření disertační práce.

\section{OBSAH PŘEDMĚTU}

1. Samostatná tvưrčí vědecká práce studenta pod vedením školitele

2. Účast a podíl na organizaci odborných seminářủ, workshopů či konferencí

3. Př́íprava publikačních výstupů ve vztahu ke studovanému oboru a tématu disertační práce ve formě př́spěvku ve sborníku z indexované mezinárodní konference, kapitoly v monografii či článku v recenzovaném odborném časopise

\section{OBSAH PŘEDMĚTU S DALŠí SPECIFIKACÍ}

1. Zvládnutí práce s dostupnými publikačními databázemi.

2. Řešení konkrétního výzkumného problému.

3. Seznámení se s rozdíly ve struktuře specifických druhů publikačních výstupů (konferenční př́spěvek, článek v časopise, kapitola v monografii, ...).

4. Další formální náležitosti odborného příspěvku (anotace, afiliace autorů, JEL kódy, zdroje financování, aj.). 


\section{LITERATURA}

$\checkmark$ Dle pokynů školitele

\section{POŽADAVKY NA STUDENTA}

1. Příprava vědeckých výstupů ve vztahu ke studovanému oboru a tématu disertační práce.

2. Úspěšné publikování vědeckého příspěvku minimálně v jedné z následujících forem:

a) příspěvek ve sborníku z indexované mezinárodní vědecké konference;

b) kapitola v monografii v minimálním rozsahu $1 \mathrm{AA}$;

c) dva odborné články v recenzovaných odborných časopisech.

\section{FORMA A ROZSAH VÝUKY}

Výuka předmětu probíhá formou individuálních konzultací se školitelem, speciálních seminářu organizovaných pro doktorandy, účastí na odborných kolokviích a samostatnou prací studenta pod vedením školitele.

\section{DALŠÍ INFORMACE GARANTA PŘEDMĚTU}

Podmínkou získání zápočtu je zanesení publikačního výstupu do univerzitní databáze výsledků ZČU (OBD) minimálně ve stavu „Ke kontrole“.

\section{KONTAKT NA GARANTA PŘEDMĚTU}

\begin{tabular}{|l|l|}
\hline E-mail: & plevny@kem.zcu.cz \\
\hline Telefon: & +420377633501 \\
\hline Konzultační hodiny: & (dle aktuálního zadání na www.fek.zcu.cz) \\
\hline Kancelář: & UL 403, Univerzitní 22, 306 14 Plzeň \\
& CD 301, Hradební 22, Cheb \\
\hline
\end{tabular}


Vědecko-výzkumná činnost 3

\section{METODICKÝ LIST PRO PŘEDMĚT DOKTORSKÉHO STUDIJNÍHO PROGRAMU P6208 EKONOMIKA A MANAGEMENT}

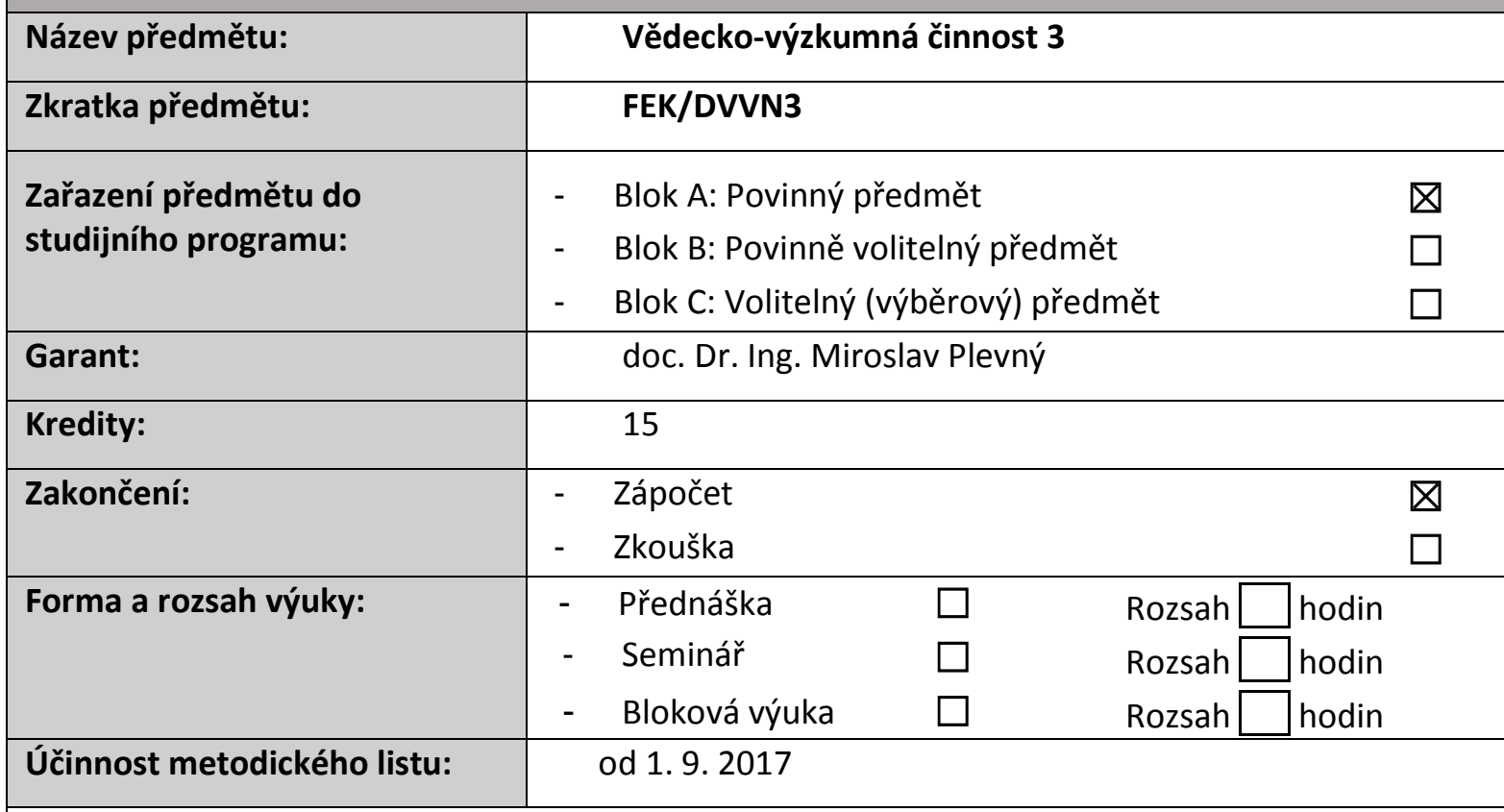

\section{CÍL PŘEDMĚTU}

Vést a podporovat studenta $v$ samostatné tvưrčí vědecké práci; zapojovat jej do organizování odborných kolokvií a konferencí; zdokonalovat jej v prípravě publikačních výstupů tvůrčí činnosti ve formě vědeckých článků či kapitol $v$ monografiích, a to vše primárně $v$ oblasti tematického zaměření disertační práce.

\section{OBSAH PŘEDMĚTU}

1. Samostatná tvưrčí vědecká práce studenta pod vedením školitele

2. Účast a podíl na organizaci odborných seminářủ, workshopů či konferencí

3. Příprava publikačních výstupů ve vztahu ke studovanému oboru a tématu disertační práce ve formě př́spěvku ve sborníku z indexované mezinárodní konference, kapitoly v monografii či článku v recenzovaném odborném časopise

\section{OBSAH PŘEDMĚTU S DALŠÍ SPECIFIKACÍ}

1. Pokročilá práce $s$ dostupnými publikačními databázemi.

2. Řešení konkrétního výzkumného problému.

3. Zvládání př́pravy specifických druhů publikačních výstupů včetně všech požadovaných formálních náležitostí odborného příspěvku. 


\section{LITERATURA}

$\checkmark$ Dle pokynů školitele

\section{POŽADAVKY NA STUDENTA}

1. Příprava vědeckých výstupů ve vztahu ke studovanému oboru a tématu disertační práce.

2. Úspěšné publikování vědeckého příspěvku minimálně v jedné z následujících forem:

a) příspěvek ve sborníku z indexované mezinárodní vědecké konference;

b) kapitola v monografii v minimálním rozsahu 1AA;

c) dva odborné články v recenzovaných odborných časopisech.

\section{FORMA A ROZSAH VÝUKY}

Výuka předmětu probíhá formou individuálních konzultací se školitelem, speciálních seminářů organizovaných pro doktorandy, účastí na odborných kolokviích a samostatnou prací studenta pod vedením školitele.

\section{DALŠÍ INFORMACE GARANTA PŘEDMĚTU}

Podmínkou získání zápočtu je zanesení publikačního výstupu do univerzitní databáze výsledků ZČU (OBD) minimálně ve stavu „Ke kontrole“.

\section{KONTAKT NA GARANTA PŘEDMĚTU}

\begin{tabular}{|l|l|}
\hline E-mail: & plevny@kem.zcu.cz \\
\hline Telefon: & +420377633501 \\
\hline Konzultační hodiny: & (dle aktuálního zadání na www.fek.zcu.cz) \\
\hline Kancelář: & UL 403, Univerzitní 22, 306 14 Plzeň \\
& $\mathrm{CD} 301$, Hradební 22, Cheb \\
\hline
\end{tabular}


Vědecko-výzkumná činnost 4

\section{METODICKÝ LIST PRO PŘEDMĚT DOKTORSKÉHO STUDIJNÍHO PROGRAMU P6208 EKONOMIKA A MANAGEMENT}

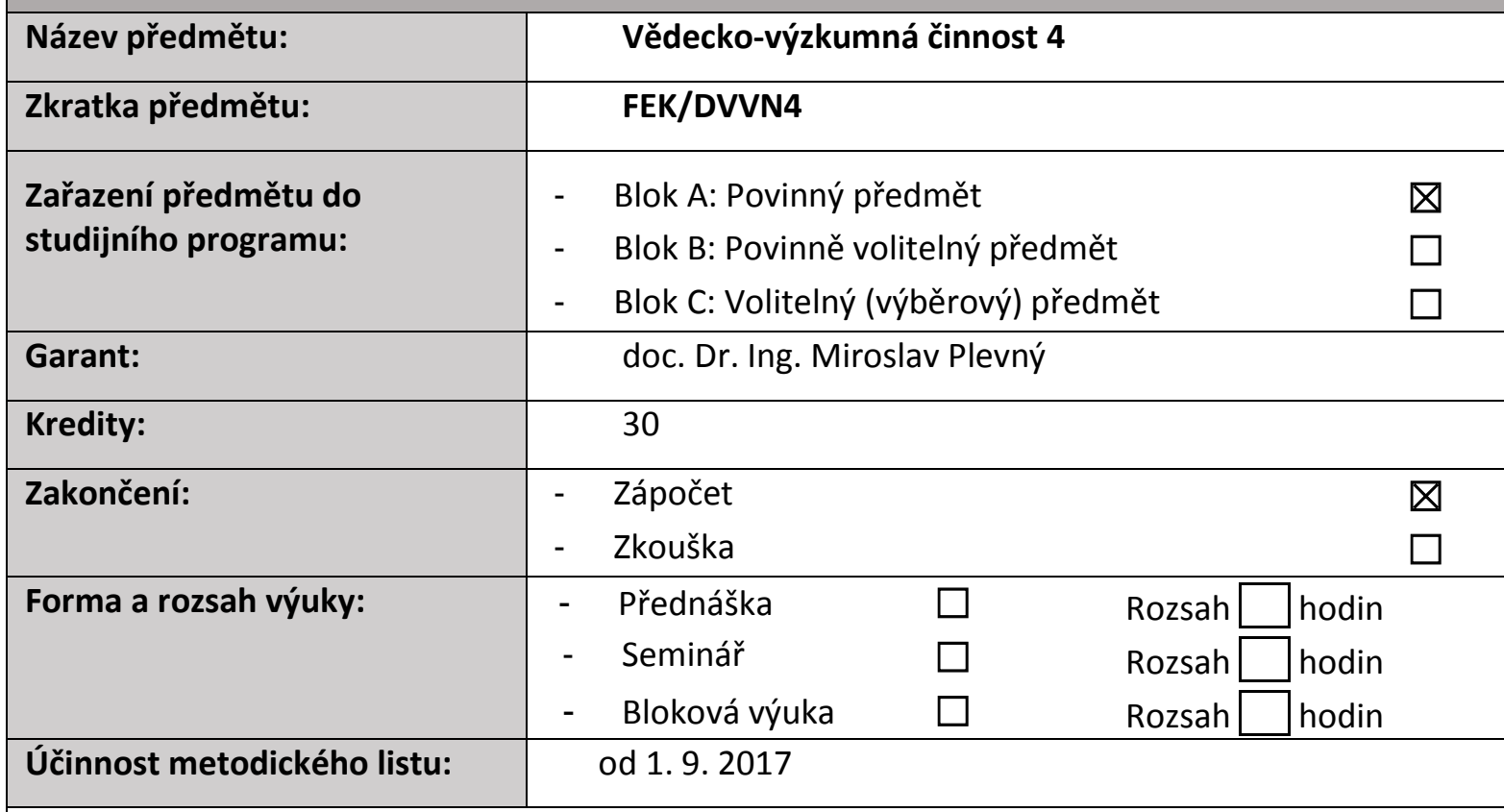

\section{CÍL PŘEDMĚTU}

Vést a podporovat studenta $v$ samostatné tvůrčí vědecké práci; zapojovat jej do organizování odborných kolokvií a konferencí; zdokonalovat jej v prípravě prestižních publikačních výstupů tvůrčí činnosti ve formě vědeckých článků $v$ indexovaných časopisech, primárně $v$ oblasti tematického zaměření disertační práce.

\section{OBSAH PŘEDMĚTU}

1. Tvưrčí vědecká práce studenta (samostatná i v rámci výzkumného týmu) pod vedením školitele

2. Účast a podíl na organizaci odborných seminářù, workshopů či konferencí

3. Př́prava publikačního výstupu ve vztahu ke studovanému oboru a tématu disertační práce ve formě odborného článku v časopise indexovaném ve WoS či Scopus

\section{OBSAH PŘEDMĚTU S DALŠí SPECIFIKACÍ}

1. Pokročilá práce s dostupnými publikačními databázemi.

2. Řešení konkrétního výzkumného problému.

3. Struktura a standardní náležitosti publikačního výstupu ve formě článku v indexovaném vědeckém časopise.

4. Př́íprava formální podoby článku podle „Požadavků pro autory“ v konkrétním vědeckém časopise.

5. Příprava dalších doprovodných specifických požadavků při publikování článků (prohlášení autorů, krycí list, anonymizovaná podoba př́spěvku, hlavní body článku, krátká CV autorů apod.). 
6. Seznámení se a zvládnutí práce se standardním webovým systémem pro vkládání odborných článků a řízení recenzního procesu v roli korespondujícího autora.

7. Možné reakce na výsledky recenzního řízení.

\section{LITERATURA}

$\checkmark$ Dle pokynů školitele

\section{POŽADAVKY NA STUDENTA}

1. Příprava vědeckých výstupů z vlastního výzkumu voblasti studovaného oboru a tématu disertační práce.

2. Úspěšné publikování nebo prokazatelné přijetí k publikování autorského či spoluautorského vědeckého článku v indexovaném vědeckém časopise (časopis s nenulovým impakt faktorem v databázi WoS či nenulovým SJR indexem v databázi Scopus).

\section{FORMA A ROZSAH VÝUKY}

Výuka předmětu probíhá formou individuálních konzultací se školitelem, speciálních seminářů organizovaných pro doktorandy, účastí na odborných kolokviích a samostatnou prací studenta pod vedením školitele.

\section{DALŠÍ INFORMACE GARANTA PŘEDMĚTU}

Podmínkou získání zápočtu je zanesení publikačního výstupu do univerzitní databáze výsledků ZČU (OBD) minimálně ve stavu „Ke kontrole“, případně doložení přijetí článku k publikování v daném časopise.

\section{KONTAKT NA GARANTA PŘEDMĚTU}

\begin{tabular}{|l|l|}
\hline E-mail: & plevny@kem.zcu.cz \\
\hline Telefon: & +420377633501 \\
\hline Konzultační hodiny: & (dle aktuálního zadání na www.fek.zcu.cz) \\
\hline Kancelář: & UL 403, Univerzitní 22, 306 14 Plzeň \\
& $\mathrm{CD} 301$, Hradební 22, Cheb \\
\hline
\end{tabular}


Pedagogické působení 1

\section{METODICKÝ LIST PRO PŘEDMĚT DOKTORSKÉHO STUDIJNÍHO PROGRAMU P6208 EKONOMIKA A MANAGEMENT}

\begin{tabular}{|c|c|c|c|c|c|c|}
\hline Název předmětu: & & \multicolumn{5}{|c|}{ Pedagogické působení 1} \\
\hline Zkratka předmětu: & & \multicolumn{5}{|l|}{ FEK/DPPN1 } \\
\hline $\begin{array}{l}\text { Zařazení předmětu do } \\
\text { studijního programu: }\end{array}$ & $\begin{array}{l}- \\
-\end{array}$ & \multicolumn{4}{|c|}{$\begin{array}{l}\text { Blok A: Povinný předmět } \\
\text { Blok B: Povinně volitelný předmět } \\
\text { Blok C: Volitelný (výběrový) předmět }\end{array}$} & $\begin{array}{l}\bigotimes \\
\square \\
\square\end{array}$ \\
\hline Garant: & & \multicolumn{4}{|c|}{ doc. PaedDr. Ludvík Eger, CSc. } & \\
\hline Kredity: & \multicolumn{5}{|c|}{5} & \\
\hline Zakončení: & - & \multicolumn{3}{|l|}{$\begin{array}{l}\text { Zápočet } \\
\text { Zkouška }\end{array}$} & & $\begin{array}{l}\bigotimes \\
\square\end{array}$ \\
\hline Forma a rozsah výuky: & $\begin{array}{l}- \\
- \\
-\end{array}$ & $\begin{array}{l}\text { Přednáška } \\
\text { Seminář } \\
\text { Bloková výuka }\end{array}$ & $\begin{array}{l}\square \\
\square \\
\square\end{array}$ & $\begin{array}{l}\text { Rozsah } \square \\
\text { Rozsah } 52 \\
\text { Rozsah }\end{array}$ & $\begin{array}{l}\text { hodin } \\
\text { hodin } \\
\text { hodin }\end{array}$ & \\
\hline Účinnost metodického listu: & & \multicolumn{5}{|l|}{ od 1.9. 2017} \\
\hline
\end{tabular}

\section{CÍL PŘEDMĚTU}

Připravit studenta doktorského studijního programu pro jeho možnou budoucí roli akademického pracovníka na univerzitě. Seznámit jej se základy andragogiky a se specifiky vzdělávání na univerzitě. Organizovat jeho př́pravu na praxi, tj. vedení seminářů a pod dohledem školitele i vyzkoušení si přednášky. Podporovat jej a vést $\mathrm{k}$ př́pravě studijní agendy a studijních materiálů pro bakalářské a magisterské studium. Seznámit jej se systémy administrace a řízením kvality vzdělávacího procesu na univerzitě. Poskytnout zpětnou vazbu z pedagogického působení studenta.

\section{OBSAH PŘEDMĚTU}

1. Př́íprava na vedení seminářů na bakalářském či magisterském stupni studia

2. Výuka v semestru (4 hod. / týden) + odpovídající činnost na evaluaci

3. Alternativně aktivní príprava a účast na letní škole či odborných workshopech pro studenty bakalářského a magisterského stupně studia

4. U studentů kombinované formy i kombinace s odbornou přednáškou a dalším pedagogickým vytížením v odpovídajícím rozsahu

5. Případná spoluúčast na prípravě skript, e-learningu či jiných studijních materiálech

6. Vedení bakalářských prací

7. V prípadě nenaplnění prímé vyučovací povinnosti 4hod. týdně na FEK ZČU student doloží pedagogické působení žádostí o uznání zápočtu s popisem skutečně vykonaných pedagogických činností 


\section{OBSAH PŘEDMĚTU S DALŠÍ SPECIFIKACÍ}

1. Obvykle se jedná o vedení seminářů na bakalářském či magisterském stupni studia včetně přípravy výuky a její evaluace dle upřesnění zadání školitelem či vedoucím katedry.

2. Alternativně je možné činnost plnit spoluúčastí na letní škole, jiných workshopech pro studenty apod.

3. Částečně je také možné započítat přípravu studijních materiálů pro studenty nižších úrovní studia a zpracování posudků oponenta kvalifikační práce.

4. Student se také účastní administrativních a evaluačních prací spojených s přidělenou pedagogickou činností.

5. U externích studentů je možné na základě žádosti a doložení praxe - výuky na jiné vŠ uznat předmět za pedagogické působení studenta, ale jen v semestru, kdy výuka na jiné vš reálně probíhala.

6. Podobně se za část pedagogického působení může uznat konzultační činnost při vedení bakalářských prací na vysoké škole. $V$ prípadě vedení prací na jiné $V S ̌$ je opět nutné tento fakt věrohodně doložit. Nicméně platí, že student studuje na FEK ZČU v Plzni a dle rozhodnutí školitele a př́slušné odborné katedry se zapojuje do vedení prací na FEK ZČU.

\section{LITERATURA}

\section{Základní:}

$\checkmark$ Podlahová, L. (2012). Didaktika pro vysokoškolské učitele. Praha: Grada.

$\checkmark$ Rohlíková, L., Vejvodová, J. (2010). Vyučovací metody na vysoké škole. Plzeň: ZČU v Plzni.

$\checkmark$ Eger, L. (2012). Vzdělávání dospělých a ICT. Plzeň: NAVA.

\section{Doporučená:}

$\checkmark \quad$ Literatura z oblasti vzdělávání dospělých.

\section{POŽADAVKY NA STUDENTA}

1. Aktivně se připravit na výuku přidělených seminářu (přidělují školitel + vedoucí katedry).

2. Vést výuku v seminárích.

3. Průběžně realizovat pedagogickou evaluaci studentů.

4. Spolu s garantem předmětu se podílet na zápočtech z předmětu a adekvátně na zkoušce (zadání a opravy písemných prací apod.).

5. Vyhodnotit svoji účast na vedení výuky stručnou zprávou (rozsah $2 \mathrm{~s}$. / předmět) a s odstupem s garantem předmětu zhodnotit i výstupy studentského hodnocení v systému EVA na ZČU v Plzni.

6. Nejedná-li se jen o prezenční výuku, plnit zadané pedagogické úkoly školitelem a vedením katedry.

\section{FORMA A ROZSAH VÝUKY}

Výuka předmětu probíhá formou individuálních konzultací s garantem předmětu a s garantem vyučovaného předmětu.

\section{DALŠÍ INFORMACE GARANTA PŘEDMĚTU}




\section{KONTAKT NA GARANTA PŘEDMĚTU}

\begin{tabular}{|l|l|}
\hline E-mail: & leger@kmo.czu.cz \\
\hline Telefon: & +420377633312 \\
\hline Konzultační hodiny: & (dle aktuálního zadání na www.fek.zcu.cz) \\
\hline Kancelář: & UK 518, FEK ZČU, Univerzitní 22, 306 14 Plzeň \\
\hline
\end{tabular}


Pedagogické působení 2

\section{METODICKÝ LIST PRO PŘEDMĚT DOKTORSKÉHO STUDIJNÍHO PROGRAMU P6208 EKONOMIKA A MANAGEMENT}

\begin{tabular}{|c|c|c|c|c|c|c|}
\hline Název předmětu: & & \multicolumn{5}{|c|}{ Pedagogické působení 2} \\
\hline Zkratka předmětu: & & \multicolumn{5}{|l|}{ FEK/DPPN2 } \\
\hline $\begin{array}{l}\text { Zařazení předmětu do } \\
\text { studijního programu: }\end{array}$ & $\begin{array}{l}- \\
-\end{array}$ & \multicolumn{4}{|c|}{$\begin{array}{l}\text { Blok A: Povinný předmět } \\
\text { Blok B: Povinně volitelný předmět } \\
\text { Blok C: Volitelný (výběrový) předmět }\end{array}$} & $\begin{array}{l}\bigotimes \\
\square \\
\square\end{array}$ \\
\hline Garant: & & \multicolumn{4}{|c|}{ doc. PaedDr. Ludvík Eger, CSc. } & \\
\hline Kredity: & \multicolumn{5}{|c|}{5} & \\
\hline Zakončení: & - & \multicolumn{3}{|l|}{$\begin{array}{l}\text { Zápočet } \\
\text { Zkouška }\end{array}$} & & $\begin{array}{l}\bigotimes \\
\square\end{array}$ \\
\hline Forma a rozsah výuky: & $\begin{array}{l}- \\
- \\
-\end{array}$ & $\begin{array}{l}\text { Přednáška } \\
\text { Seminář } \\
\text { Bloková výuka }\end{array}$ & $\begin{array}{l}\square \\
\square \\
\square\end{array}$ & $\begin{array}{l}\text { Rozsah } \square \\
\text { Rozsah } 52 \\
\text { Rozsah }\end{array}$ & $\begin{array}{l}\text { hodin } \\
\text { hodin } \\
\text { hodin }\end{array}$ & \\
\hline Účinnost metodického listu: & & \multicolumn{5}{|l|}{ od 1.9. 2017} \\
\hline
\end{tabular}

\section{CÍL PŘEDMĚTU}

Připravit studenta doktorského studijního programu pro jeho možnou budoucí roli akademického pracovníka na univerzitě. Seznámit jej se základy andragogiky a se specifiky vzdělávání na univerzitě. Organizovat jeho př́pravu na praxi, tj. vedení seminářů a pod dohledem školitele i vyzkoušení si přednášky. Podporovat jej a vést $\mathrm{k}$ přípravě studijní agendy a studijních materiálů pro bakalářské a magisterské studium. Seznámit jej se systémy administrace a řízením kvality vzdělávacího procesu na univerzitě. Poskytnout zpětnou vazbu z pedagogického působení studenta.

\section{OBSAH PŘEDMĚTU}

1. Př́íprava na vedení seminářů na bakalářském či magisterském stupni studia

2. Výuka v semestru (4 hod. / týden) + odpovídající činnost na evaluaci

3. Alternativně aktivní príprava a účast na letní škole či odborných workshopech pro studenty bakalářského a magisterského stupně studia

4. U studentů kombinované formy i kombinace s odbornou přednáškou a dalším pedagogickým vytížením v odpovídajícím rozsahu

5. Př́padná spoluúčast na prípravě skript, e-learningu či jiných studijních materiálech

6. Vedení bakalářských prací

7. V prípadě nenaplnění prímé vyučovací povinnosti 4hod. týdně na FEK ZČU student doloží pedagogické působení žádostí o uznání zápočtu s popisem skutečně vykonaných pedagogických činností 


\section{OBSAH PŘEDMĚTU S DALŠÍ SPECIFIKACÍ}

1. Obvykle se jedná o vedení seminářů na bakalářském či magisterském stupni studia včetně přípravy výuky a její evaluace dle upřesnění zadání školitelem či vedoucím katedry.

2. Alternativně je možné činnost plnit spoluúčastí na letní škole, jiných workshopech pro studenty apod.

3. Částečně je také možné započítat přípravu studijních materiálů pro studenty nižších úrovní studia a zpracování posudků oponenta kvalifikační práce.

4. Student se také účastní administrativních a evaluačních prací spojených s přidělenou pedagogickou činností.

5. U externích studentů je možné na základě žádosti a doložení praxe - výuky na jiné VŠ uznat předmět za pedagogické působení studenta, ale jen v semestru, kdy výuka na jiné vš reálně probíhala.

6. Podobně se za část pedagogického působení může uznat konzultační činnost při vedení bakalářských prací na vysoké škole. $V$ prípadě vedení prací na jiné $V S ̌$ je opět nutné tento fakt věrohodně doložit. Nicméně platí, že student studuje na FEK ZČU v Plzni a dle rozhodnutí školitele a př́slušné odborné katedry se zapojuje do vedení prací na FEK ZČU.

\section{LITERATURA}

\section{Základní:}

$\checkmark$ Podlahová, L. (2012). Didaktika pro vysokoškolské učitele. Praha: Grada.

$\checkmark$ Rohlíková, L., Vejvodová, J. (2010). Vyučovací metody na vysoké škole. Plzeň: ZČU v Plzni.

$\checkmark$ Eger, L. (2012). Vzdělávání dospělých a ICT. Plzeň: NAVA.

\section{Doporučená:}

$\checkmark \quad$ Literatura z oblasti vzdělávání dospělých.

\section{POŽADAVKY NA STUDENTA}

1. Aktivně se připravit na výuku přidělených seminářu (přidělují školitel + vedoucí katedry).

2. Vést výuku v seminárích.

3. Průběžně realizovat pedagogickou evaluaci studentů.

4. Spolu s garantem předmětu se podílet na zápočtech z předmětu a adekvátně na zkoušce (zadání a opravy písemných prací apod.).

5. Vyhodnotit svoji účast na vedení výuky stručnou zprávou (rozsah $2 \mathrm{~s}$. / předmět) a s odstupem s garantem předmětu zhodnotit i výstupy studentského hodnocení v systému EVA na ZČU v Plzni.

6. Nejedná-li se jen o prezenční výuku, plnit zadané pedagogické úkoly školitelem a vedením katedry.

\section{FORMA A ROZSAH VÝUKY}

Výuka předmětu probíhá formou individuálních konzultací s garantem předmětu a s garantem vyučovaného předmětu.

\section{DALŠí INFORMACE GARANTA PŘEDMĚTU}




\section{KONTAKT NA GARANTA PŘEDMĚTU}

\begin{tabular}{|l|l|}
\hline E-mail: & leger@kmo.czu.cz \\
\hline Telefon: & +420377633312 \\
\hline Konzultační hodiny: & (dle aktuálního zadání na www.fek.zcu.cz) \\
\hline Kancelář: & UK 518, FEK ZČU, Univerzitní 22, 306 14 Plzeň \\
\hline
\end{tabular}


Pedagogické působení 3

\section{METODICKÝ LIST PRO PŘEDMĚT DOKTORSKÉHO STUDIJNÍHO PROGRAMU P6208 EKONOMIKA A MANAGEMENT}

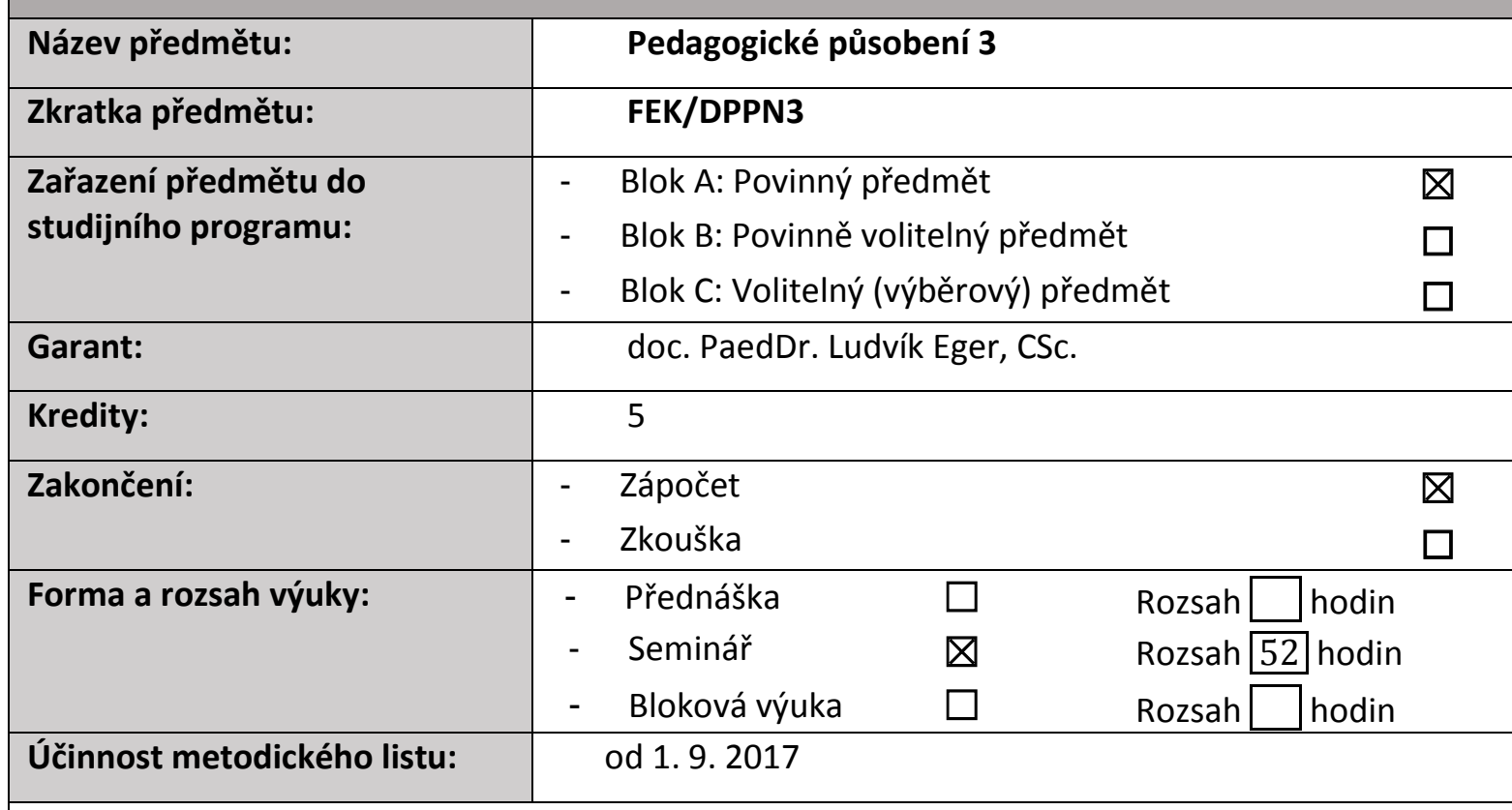

\section{CÍL PŘEDMĚTU}

Připravit studenta doktorského studijního programu pro jeho možnou budoucí roli akademického pracovníka na univerzitě. Seznámit jej se základy andragogiky a se specifiky vzdělávání na univerzitě. Organizovat jeho př́ipravu na praxi, tj. vedení seminářů a pod dohledem školitele i vyzkoušení si přednášky. Podporovat jej a vést $\mathrm{k}$ přípravě studijní agendy a studijních materiálů pro bakalářské a magisterské studium. Seznámit jej se systémy administrace a řízením kvality vzdělávacího procesu na univerzitě. Poskytnout zpětnou vazbu z pedagogického působení studenta.

\section{OBSAH PŘEDMĚTU}

1. Př́íprava na vedení seminářů na bakalářském či magisterském stupni studia

2. Výuka v semestru (4 hod. / týden) + odpovídající činnost na evaluaci

3. Alternativně aktivní príprava a účast na letní škole či odborných workshopech pro studenty bakalářského a magisterského stupně studia

4. U studentů kombinované formy i kombinace s odbornou přednáškou a dalším pedagogickým vytížením v odpovídajícím rozsahu

5. Případná spoluúčast na př́pravě skript, e-learningu či jiných studijních materiálech

6. Vedení bakalářských prací

7. V prípadě nenaplnění přímé vyučovací povinnosti 4hod. týdně na FEK ZČU student doloží pedagogické působení žádostí o uznání zápočtu s popisem skutečně vykonaných pedagogických činností 


\section{OBSAH PŘEDMĚTU S DALŠÍ SPECIFIKACÍ}

1. Obvykle se jedná o vedení seminářů na bakalářském či magisterském stupni studia včetně přípravy výuky a její evaluace dle upřesnění zadání školitelem či vedoucím katedry.

2. Alternativně je možné činnost plnit spoluúčastí na letní škole, jiných workshopech pro studenty apod.

3. Částečně je také možné započítat přípravu studijních materiálů pro studenty nižších úrovní studia a zpracování posudků oponenta kvalifikační práce.

4. Student se také účastní administrativních a evaluačních prací spojených s přidělenou pedagogickou činností.

5. U externích studentů je možné na základě žádosti a doložení praxe - výuky na jiné VŠ uznat předmět za pedagogické působení studenta, ale jen v semestru, kdy výuka na jiné vš reálně probíhala.

6. Podobně se za část pedagogického působení může uznat konzultační činnost při vedení bakalářských prací na vysoké škole. $V$ prípadě vedení prací na jiné $V S ̌$ je opět nutné tento fakt věrohodně doložit. Nicméně platí, že student studuje na FEK ZČU v Plzni a dle rozhodnutí školitele a př́slušné odborné katedry se zapojuje do vedení prací na FEK ZČU.

\section{LITERATURA}

\section{Základní:}

$\checkmark$ Podlahová, L. (2012). Didaktika pro vysokoškolské učitele. Praha: Grada.

$\checkmark$ Rohlíková, L., Vejvodová, J. (2010). Vyučovací metody na vysoké škole. Plzeň: ZČU v Plzni.

$\checkmark$ Eger, L. (2012). Vzdělávání dospělých a ICT. Plzeň: NAVA.

\section{Doporučená:}

$\checkmark \quad$ Literatura z oblasti vzdělávání dospělých.

\section{POŽADAVKY NA STUDENTA}

1. Aktivně se připravit na výuku přidělených seminářu (přidělují školitel + vedoucí katedry).

2. Vést výuku v seminárích.

3. Průběžně realizovat pedagogickou evaluaci studentů.

4. Spolu s garantem předmětu se podílet na zápočtech z předmětu a adekvátně na zkoušce (zadání a opravy písemných prací apod.).

5. Vyhodnotit svoji účast na vedení výuky stručnou zprávou (rozsah $2 \mathrm{~s}$. / předmět) a s odstupem s garantem předmětu zhodnotit i výstupy studentského hodnocení v systému EVA na ZČU v Plzni.

6. Nejedná-li se jen o prezenční výuku, plnit zadané pedagogické úkoly školitelem a vedením katedry.

\section{FORMA A ROZSAH VÝUKY}

Výuka předmětu probíhá formou individuálních konzultací s garantem předmětu a s garantem vyučovaného předmětu.

\section{DALŠí INFORMACE GARANTA PŘEDMĚTU}




\section{KONTAKT NA GARANTA PŘEDMĚTU}

\begin{tabular}{|l|l|}
\hline E-mail: & leger@kmo.czu.cz \\
\hline Telefon: & +420377633312 \\
\hline Konzultační hodiny: & (dle aktuálního zadání na www.fek.zcu.cz) \\
\hline Kancelář: & UK 518, FEK ZČU, Univerzitní 22, 306 14 Plzeň \\
\hline
\end{tabular}


Pedagogické působení 4

\section{METODICKÝ LIST PRO PŘEDMĚT DOKTORSKÉHO STUDIJNÍHO PROGRAMU P6208 EKONOMIKA A MANAGEMENT}

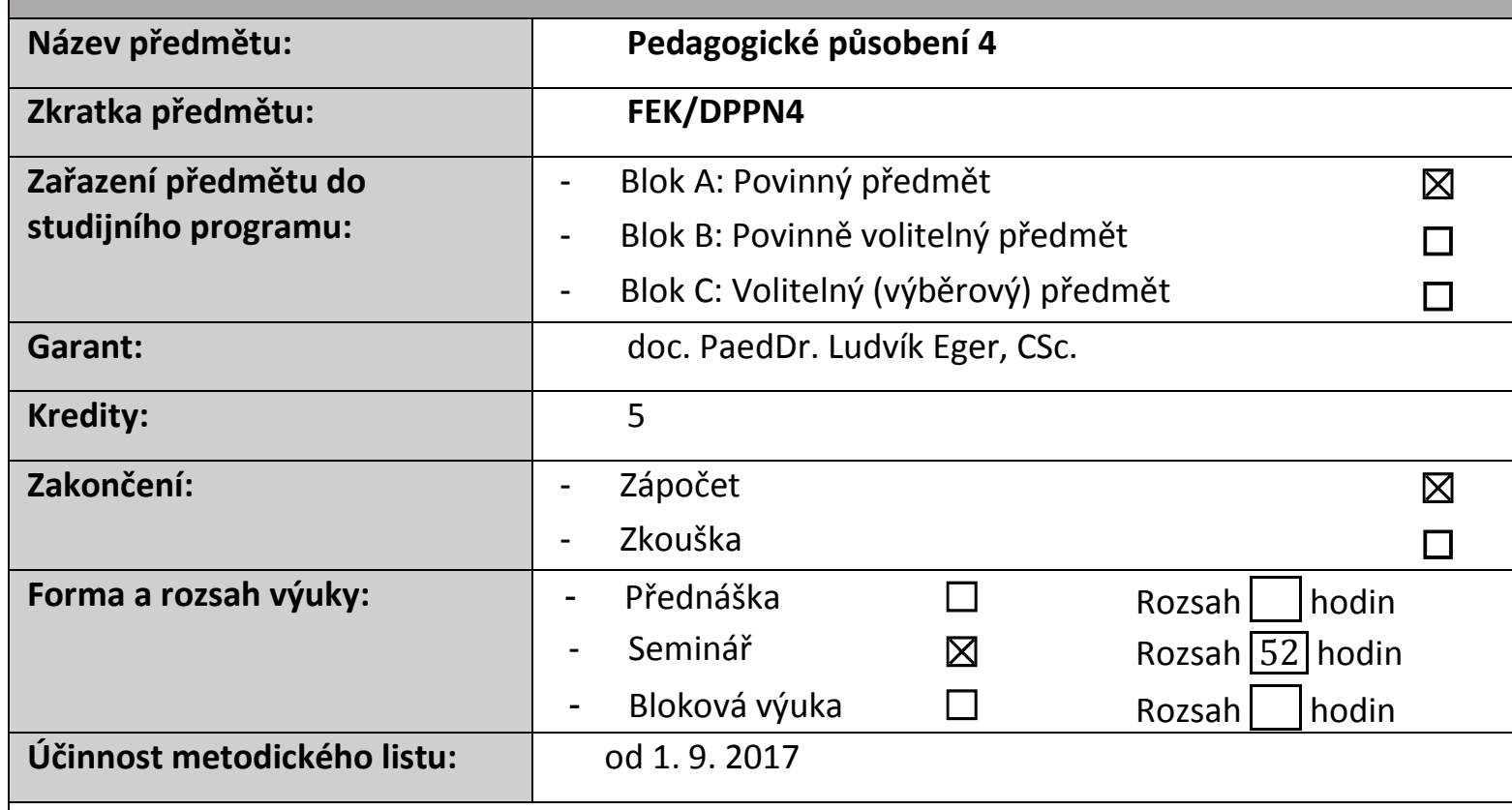

\section{CÍL PŘEDMĚTU}

Připravit studenta doktorského studijního programu pro jeho možnou budoucí roli akademického pracovníka na univerzitě. Seznámit jej se základy andragogiky a se specifiky vzdělávání na univerzitě. Organizovat jeho př́ipravu na praxi, tj. vedení seminářů a pod dohledem školitele i vyzkoušení si přednášky. Podporovat jej a vést $\mathrm{k}$ přípravě studijní agendy a studijních materiálů pro bakalářské a magisterské studium. Seznámit jej se systémy administrace a řízením kvality vzdělávacího procesu na univerzitě. Poskytnout zpětnou vazbu z pedagogického působení studenta.

\section{OBSAH PŘEDMĚTU}

1. Př́íprava na vedení seminářů na bakalářském či magisterském stupni studia

2. Výuka v semestru (4 hod. / týden) + odpovídající činnost na evaluaci

3. Alternativně aktivní príprava a účast na letní škole či odborných workshopech pro studenty bakalářského a magisterského stupně studia

4. U studentů kombinované formy i kombinace s odbornou přednáškou a dalším pedagogickým vytížením v odpovídajícím rozsahu

5. Případná spoluúčast na př́pravě skript, e-learningu či jiných studijních materiálech

6. Vedení bakalářských prací

7. V prípadě nenaplnění přímé vyučovací povinnosti 4hod. týdně na FEK ZČU student doloží pedagogické působení žádostí o uznání zápočtu s popisem skutečně vykonaných pedagogických činností 


\section{OBSAH PŘEDMĚTU S DALŠÍ SPECIFIKACÍ}

1. Obvykle se jedná o vedení seminářů na bakalářském či magisterském stupni studia včetně přípravy výuky a její evaluace dle upřesnění zadání školitelem či vedoucím katedry.

2. Alternativně je možné činnost plnit spoluúčastí na letní škole, jiných workshopech pro studenty apod.

3. Částečně je také možné započítat přípravu studijních materiálů pro studenty nižších úrovní studia a zpracování posudků oponenta kvalifikační práce.

4. Student se také účastní administrativních a evaluačních prací spojených s přidělenou pedagogickou činností.

5. U externích studentů je možné na základě žádosti a doložení praxe - výuky na jiné vŠ uznat předmět za pedagogické působení studenta, ale jen v semestru, kdy výuka na jiné vš reálně probíhala.

6. Podobně se za část pedagogického působení může uznat konzultační činnost při vedení bakalářských prací na vysoké škole. $V$ prípadě vedení prací na jiné $V S ̌$ je opět nutné tento fakt věrohodně doložit. Nicméně platí, že student studuje na FEK ZČU v Plzni a dle rozhodnutí školitele a př́slušné odborné katedry se zapojuje do vedení prací na FEK ZČU.

\section{LITERATURA}

\section{Základní:}

$\checkmark$ Podlahová, L. (2012). Didaktika pro vysokoškolské učitele. Praha: Grada.

$\checkmark$ Rohlíková, L., Vejvodová, J. (2010). Vyučovací metody na vysoké škole. Plzeň: ZČU v Plzni.

$\checkmark$ Eger, L. (2012). Vzdělávání dospělých a ICT. Plzeň: NAVA.

\section{Doporučená:}

$\checkmark \quad$ Literatura z oblasti vzdělávání dospělých.

\section{POŽADAVKY NA STUDENTA}

1. Aktivně se připravit na výuku přidělených seminářu (přidělují školitel + vedoucí katedry).

2. Vést výuku v seminárích.

3. Průběžně realizovat pedagogickou evaluaci studentů.

4. Spolu s garantem předmětu se podílet na zápočtech z předmětu a adekvátně na zkoušce (zadání a opravy písemných prací apod.).

5. Vyhodnotit svoji účast na vedení výuky stručnou zprávou (rozsah $2 \mathrm{~s}$. / předmět) a s odstupem s garantem předmětu zhodnotit i výstupy studentského hodnocení v systému EVA na ZČU v Plzni.

6. Nejedná-li se jen o prezenční výuku, plnit zadané pedagogické úkoly školitelem a vedením katedry.

\section{FORMA A ROZSAH VÝUKY}

Výuka předmětu probíhá formou individuálních konzultací s garantem předmětu a s garantem vyučovaného předmětu.

\section{DALŠí INFORMACE GARANTA PŘEDMĚTU}




\section{KONTAKT NA GARANTA PŘEDMĚTU}

\begin{tabular}{|l|l|}
\hline E-mail: & leger@kmo.czu.cz \\
\hline Telefon: & +420377633312 \\
\hline Konzultační hodiny: & (dle aktuálního zadání na www.fek.zcu.cz) \\
\hline Kancelář: & UK 518, FEK ZČU, Univerzitní 22, 306 14 Plzeň \\
\hline
\end{tabular}


Pedagogické působení 5

\section{METODICKÝ LIST PRO PŘEDMĚT DOKTORSKÉHO STUDIJNÍHO PROGRAMU P6208 EKONOMIKA A MANAGEMENT}

\begin{tabular}{|c|c|c|c|c|c|c|}
\hline Název předmětu: & & \multicolumn{5}{|c|}{ Pedagogické působení 5} \\
\hline Zkratka předmětu: & & \multicolumn{5}{|l|}{ FEK/DPPN5 } \\
\hline $\begin{array}{l}\text { Zařazení předmětu do } \\
\text { studijního programu: }\end{array}$ & $\begin{array}{l}- \\
-\end{array}$ & \multicolumn{4}{|c|}{$\begin{array}{l}\text { Blok A: Povinný předmět } \\
\text { Blok B: Povinně volitelný předmět } \\
\text { Blok C: Volitelný (výběrový) předmět }\end{array}$} & $\begin{array}{l}\bigotimes \\
\square \\
\square\end{array}$ \\
\hline Garant: & & \multicolumn{4}{|c|}{ doc. PaedDr. Ludvík Eger, CSc. } & \\
\hline Kredity: & \multicolumn{5}{|c|}{5} & \\
\hline Zakončení: & - & \multicolumn{3}{|l|}{$\begin{array}{l}\text { Zápočet } \\
\text { Zkouška }\end{array}$} & & $\begin{array}{l}\bigotimes \\
\square\end{array}$ \\
\hline Forma a rozsah výuky: & $\begin{array}{l}- \\
- \\
-\end{array}$ & $\begin{array}{l}\text { Přednáška } \\
\text { Seminář } \\
\text { Bloková výuka }\end{array}$ & $\begin{array}{l}\square \\
\square \\
\square\end{array}$ & $\begin{array}{l}\text { Rozsah } \square \\
\text { Rozsah } 52 \\
\text { Rozsah }\end{array}$ & $\begin{array}{l}\text { hodin } \\
\text { hodin } \\
\text { hodin }\end{array}$ & \\
\hline Účinnost metodického listu: & & \multicolumn{5}{|l|}{ od 1.9. 2017} \\
\hline
\end{tabular}

\section{CÍL PŘEDMĚTU}

Připravit studenta doktorského studijního programu pro jeho možnou budoucí roli akademického pracovníka na univerzitě. Seznámit jej se základy andragogiky a se specifiky vzdělávání na univerzitě. Organizovat jeho př́pravu na praxi, tj. vedení seminářů a pod dohledem školitele i vyzkoušení si přednášky. Podporovat jej a vést $\mathrm{k}$ přípravě studijní agendy a studijních materiálů pro bakalářské a magisterské studium. Seznámit jej se systémy administrace a řízením kvality vzdělávacího procesu na univerzitě. Poskytnout zpětnou vazbu z pedagogického působení studenta.

\section{OBSAH PŘEDMĚTU}

1. Př́íprava na vedení seminářů na bakalářském či magisterském stupni studia

2. Výuka v semestru (4 hod. / týden) + odpovídající činnost na evaluaci

3. Alternativně aktivní príprava a účast na letní škole či odborných workshopech pro studenty bakalářského a magisterského stupně studia

4. U studentů kombinované formy i kombinace s odbornou přednáškou a dalším pedagogickým vytížením v odpovídajícím rozsahu

5. Př́padná spoluúčast na prípravě skript, e-learningu či jiných studijních materiálech

6. Vedení bakalářských prací

7. V prípadě nenaplnění prímé vyučovací povinnosti 4hod. týdně na FEK ZČU student doloží pedagogické působení žádostí o uznání zápočtu s popisem skutečně vykonaných pedagogických činností 


\section{OBSAH PŘEDMĚTU S DALŠÍ SPECIFIKACÍ}

1. Obvykle se jedná o vedení seminářů na bakalářském či magisterském stupni studia včetně přípravy výuky a její evaluace dle upřesnění zadání školitelem či vedoucím katedry.

2. Alternativně je možné činnost plnit spoluúčastí na letní škole, jiných workshopech pro studenty apod.

3. Částečně je také možné započítat přípravu studijních materiálů pro studenty nižších úrovní studia a zpracování posudků oponenta kvalifikační práce.

4. Student se také účastní administrativních a evaluačních prací spojených s přidělenou pedagogickou činností.

5. U externích studentů je možné na základě žádosti a doložení praxe - výuky na jiné vŠ uznat předmět za pedagogické působení studenta, ale jen v semestru, kdy výuka na jiné vš reálně probíhala.

6. Podobně se za část pedagogického působení může uznat konzultační činnost při vedení bakalářských prací na vysoké škole. $V$ prípadě vedení prací na jiné $V S ̌$ je opět nutné tento fakt věrohodně doložit. Nicméně platí, že student studuje na FEK ZČU v Plzni a dle rozhodnutí školitele a př́slušné odborné katedry se zapojuje do vedení prací na FEK ZČU.

\section{LITERATURA}

\section{Základní:}

$\checkmark$ Podlahová, L. (2012). Didaktika pro vysokoškolské učitele. Praha: Grada.

$\checkmark$ Rohlíková, L., Vejvodová, J. (2010). Vyučovací metody na vysoké škole. Plzeň: ZČU v Plzni.

$\checkmark$ Eger, L. (2012). Vzdělávání dospělých a ICT. Plzeň: NAVA.

\section{Doporučená:}

$\checkmark \quad$ Literatura z oblasti vzdělávání dospělých.

\section{POŽADAVKY NA STUDENTA}

1. Aktivně se připravit na výuku přidělených seminářu (přidělují školitel + vedoucí katedry).

2. Vést výuku v seminárích.

3. Průběžně realizovat pedagogickou evaluaci studentů.

4. Spolu s garantem předmětu se podílet na zápočtech z předmětu a adekvátně na zkoušce (zadání a opravy písemných prací apod.).

5. Vyhodnotit svoji účast na vedení výuky stručnou zprávou (rozsah $2 \mathrm{~s}$. / předmět) a s odstupem s garantem předmětu zhodnotit i výstupy studentského hodnocení v systému EVA na ZČU v Plzni.

6. Nejedná-li se jen o prezenční výuku, plnit zadané pedagogické úkoly školitelem a vedením katedry.

\section{FORMA A ROZSAH VÝUKY}

Výuka předmětu probíhá formou individuálních konzultací s garantem předmětu a s garantem vyučovaného předmětu.

\section{DALŠí INFORMACE GARANTA PŘEDMĚTU}




\section{KONTAKT NA GARANTA PŘEDMĚTU}

\begin{tabular}{|l|l|}
\hline E-mail: & leger@kmo.czu.cz \\
\hline Telefon: & +420377633312 \\
\hline Konzultační hodiny: & (dle aktuálního zadání na www.fek.zcu.cz) \\
\hline Kancelář: & UK 518, FEK ZČU, Univerzitní 22, 306 14 Plzeň \\
\hline
\end{tabular}


Pedagogické působení 6

\section{METODICKÝ LIST PRO PŘEDMĚT DOKTORSKÉHO STUDIJNÍHO PROGRAMU P6208 EKONOMIKA A MANAGEMENT}

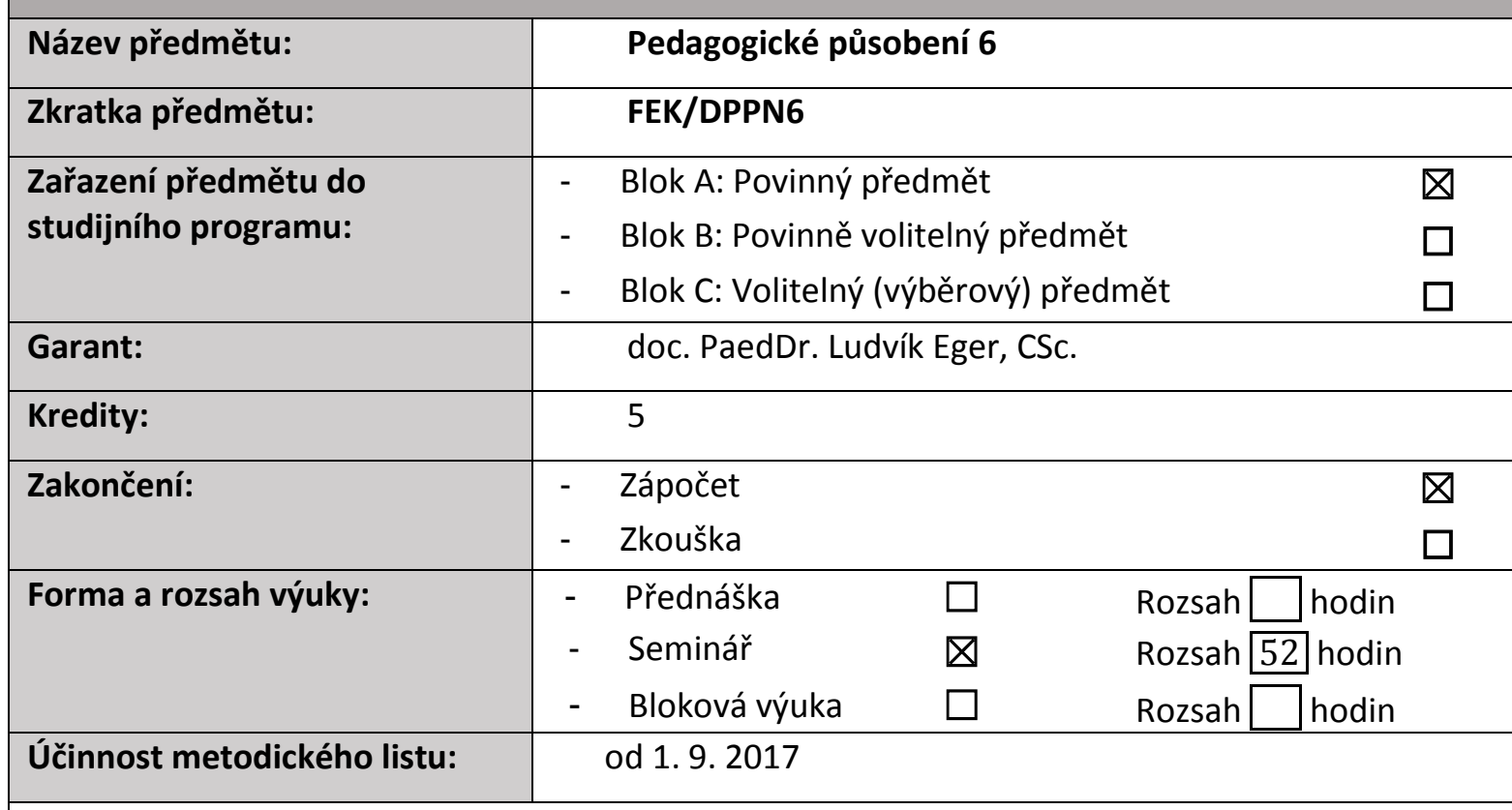

\section{CÍL PŘEDMĚTU}

Připravit studenta doktorského studijního programu pro jeho možnou budoucí roli akademického pracovníka na univerzitě. Seznámit jej se základy andragogiky a se specifiky vzdělávání na univerzitě. Organizovat jeho př́ipravu na praxi, tj. vedení seminářů a pod dohledem školitele i vyzkoušení si přednášky. Podporovat jej a vést $\mathrm{k}$ přípravě studijní agendy a studijních materiálů pro bakalářské a magisterské studium. Seznámit jej se systémy administrace a řízením kvality vzdělávacího procesu na univerzitě. Poskytnout zpětnou vazbu z pedagogického působení studenta.

\section{OBSAH PŘEDMĚTU}

1. Př́íprava na vedení seminářů na bakalářském či magisterském stupni studia

2. Výuka v semestru (4 hod. / týden) + odpovídající činnost na evaluaci

3. Alternativně aktivní príprava a účast na letní škole či odborných workshopech pro studenty bakalářského a magisterského stupně studia

4. U studentů kombinované formy i kombinace s odbornou přednáškou a dalším pedagogickým vytížením v odpovídajícím rozsahu

5. Případná spoluúčast na př́pravě skript, e-learningu či jiných studijních materiálech

6. Vedení bakalářských prací

7. V prípadě nenaplnění přímé vyučovací povinnosti 4hod. týdně na FEK ZČU student doloží pedagogické působení žádostí o uznání zápočtu s popisem skutečně vykonaných pedagogických činností 


\section{OBSAH PŘEDMĚTU S DALŠÍ SPECIFIKACÍ}

1. Obvykle se jedná o vedení seminářů na bakalářském či magisterském stupni studia včetně přípravy výuky a její evaluace dle upřesnění zadání školitelem či vedoucím katedry.

2. Alternativně je možné činnost plnit spoluúčastí na letní škole, jiných workshopech pro studenty apod.

3. Částečně je také možné započítat přípravu studijních materiálů pro studenty nižších úrovní studia a zpracování posudků oponenta kvalifikační práce.

4. Student se také účastní administrativních a evaluačních prací spojených s přidělenou pedagogickou činností.

5. U externích studentů je možné na základě žádosti a doložení praxe - výuky na jiné VŠ uznat předmět za pedagogické působení studenta, ale jen v semestru, kdy výuka na jiné vš reálně probíhala.

6. Podobně se za část pedagogického působení může uznat konzultační činnost při vedení bakalářských prací na vysoké škole. $V$ prípadě vedení prací na jiné $V S ̌$ je opět nutné tento fakt věrohodně doložit. Nicméně platí, že student studuje na FEK ZČU v Plzni a dle rozhodnutí školitele a př́slušné odborné katedry se zapojuje do vedení prací na FEK ZČU.

\section{LITERATURA}

\section{Základní:}

$\checkmark$ Podlahová, L. (2012). Didaktika pro vysokoškolské učitele. Praha: Grada.

$\checkmark$ Rohlíková, L., Vejvodová, J. (2010). Vyučovací metody na vysoké škole. Plzeň: ZČU v Plzni.

$\checkmark$ Eger, L. (2012). Vzdělávání dospělých a ICT. Plzeň: NAVA.

\section{Doporučená:}

$\checkmark \quad$ Literatura z oblasti vzdělávání dospělých.

\section{POŽADAVKY NA STUDENTA}

1. Aktivně se připravit na výuku přidělených seminářu (přidělují školitel + vedoucí katedry).

2. Vést výuku v seminárích.

3. Průběžně realizovat pedagogickou evaluaci studentů.

4. Spolu s garantem předmětu se podílet na zápočtech z předmětu a adekvátně na zkoušce (zadání a opravy písemných prací apod.).

5. Vyhodnotit svoji účast na vedení výuky stručnou zprávou (rozsah $2 \mathrm{~s}$. / předmět) a s odstupem s garantem předmětu zhodnotit i výstupy studentského hodnocení v systému EVA na ZČU v Plzni.

6. Nejedná-li se jen o prezenční výuku, plnit zadané pedagogické úkoly školitelem a vedením katedry.

\section{FORMA A ROZSAH VÝUKY}

Výuka předmětu probíhá formou individuálních konzultací s garantem předmětu a s garantem vyučovaného předmětu.

\section{DALŠÍ INFORMACE GARANTA PŘEDMĚTU}




\section{KONTAKT NA GARANTA PŘEDMĚTU}

\begin{tabular}{|l|l|}
\hline E-mail: & leger@kmo.czu.cz \\
\hline Telefon: & +420377633312 \\
\hline Konzultační hodiny: & (dle aktuálního zadání na www.fek.zcu.cz) \\
\hline Kancelář: & UK 518, FEK ZČU, Univerzitní 22, 306 14 Plzeň \\
\hline
\end{tabular}


KAPITOLA 2

Povinně-volitelné předměty

\begin{tabular}{|l|c|c|c|c|c|}
\hline \multicolumn{1}{|c|}{ Název předmětu } & $\begin{array}{c}\text { Zkratka } \\
\text { předmětu }\end{array}$ & $\begin{array}{c}\text { Počet } \\
\text { kreditů }\end{array}$ & $\begin{array}{c}\text { Zakončeno } \\
(\mathrm{Zp} / \text { Zk) }\end{array}$ & \multicolumn{2}{c|}{ Doporučeno } \\
\cline { 5 - 7 } & KFU/DEFFN & 15 & Zk & 2 & Semestr \\
\hline $\begin{array}{l}\text { Ekonomické a finanční řízení } \\
\text { firmy }\end{array}$ & KMO/DSMFN & 15 & Zk & 2 & LS \\
\hline Strategický marketing firmy & KEM/DKMEN & 15 & Zk & 2 & LS \\
\hline Kvantitativní metody v ekonomii & SMA/DZSN & 30 & Zp & 4 & ZS \\
\hline Zahraniční stáž & - & 45 & - & - & - \\
\hline $\begin{array}{l}\text { Celkem povinně-volitelné } \\
\text { předméty }\end{array}$ & & & & & \\
\hline
\end{tabular}


Ekonomické a finanční rízení firmy

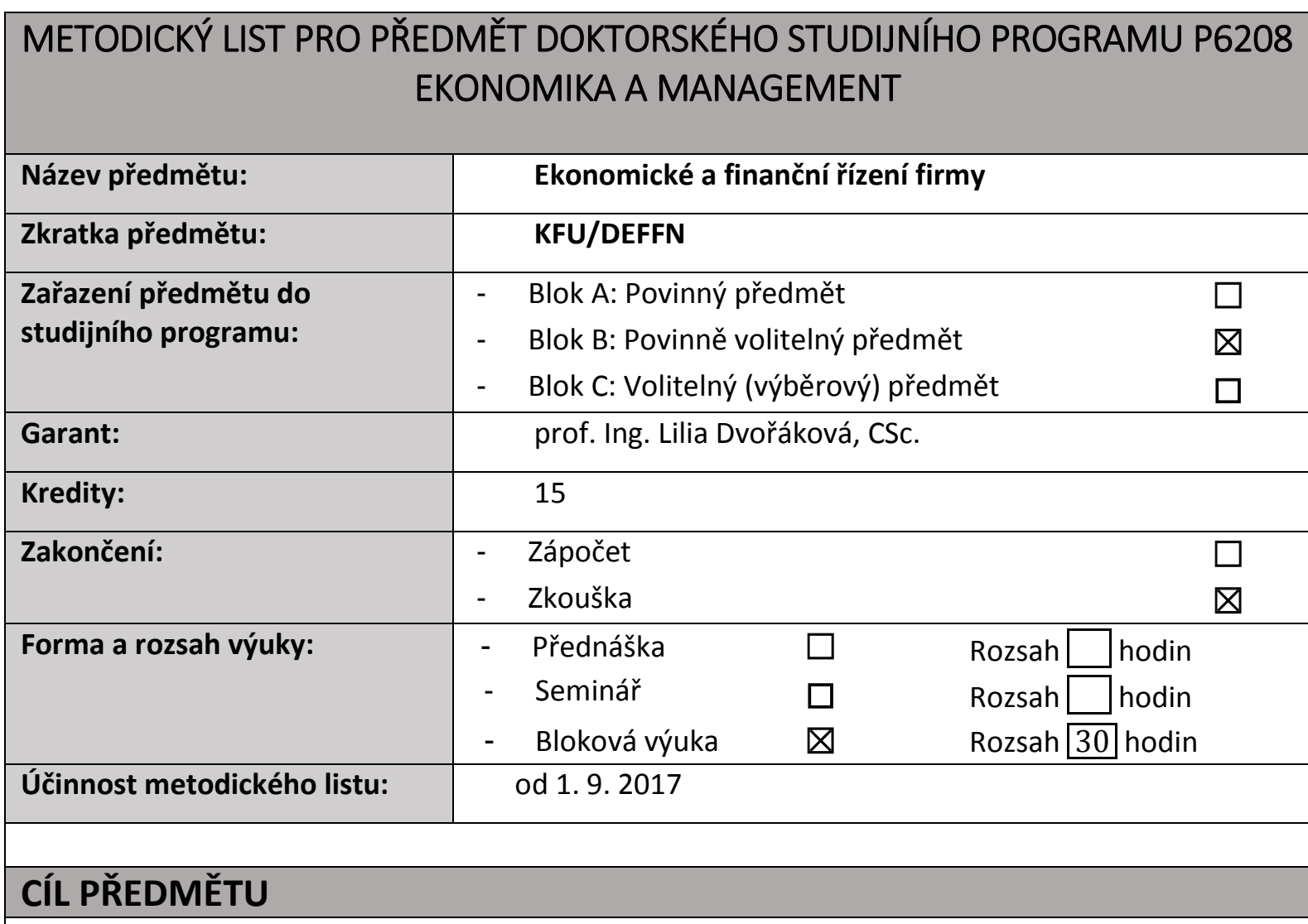

Poskytnout znalosti, vědomosti a dovednosti a diskutovat úlohu a využití metod a nástrojů finančního účetnictví, manažerského účetnictví a controllingu v ekonomickém a finančním řízení firmy na provozní, taktické a strategické úrovni. Vysvětlit vztah manažerského účetnictví a controllingu a tvorby efektivnosti a hodnotvorných rídících rozhodnutí zhodnocujících konkurenčně firmu jako celek.

\section{OBSAH PŘEDMĚTU}

1. Manažerské účetnictví, controlling a finanční rízení - obsah, cíle, funkce

2. Kritéria manažerského účetnictví, controllingu a finančního řízení

3. Př́stupy k řízení nákladů, výnosů, zisku a přidané hodnoty

4. Využití kalkulačního systému v řízení podnikových procesů a výkonů

5. Systém plánů a rozpočtů

6. Krátkodobá manažerská rozhodnutí a jejich hodnocení

7. Dlouhodobá manažerská rozhodnutí a jejich hodnocení

8. Cenová rozhodování

9. Př́stupy k měření, řizení a hodnocení výkonnosti firmy

10. Přístupy $k$ řízení a hodnocení finanční stability firmy

11. Strategicky orientované manažerské účetnictví, controlling a finanční ŕizení

12. Vývojové tendence $v$ ekonomickém a finančním řízení firmy 
1. Manažerské účetnictví, controlling a finanční rízení - obsah, cíle, funkce

a) Druhy účetních systémů

b) Manažerské účetnictví a controlling - definice, cíle, funkce

c) Metody a nástroje manažerského účetnictví a controllingu

\section{Klíčová slova:}

controlling, finanční účetnictví, manažerský informační systém, manažerské účetnictví

2. Kritéria manažerského účetnictví, controllingu a finančního řízení

a) Kritéria finanční výkonnosti

b) Kritéria finanční stability

c) Finanční, hodnotové a ekonomické pojetí nákladů

Klíčová slova:

ekonomická efektivnost, ekonomická účinnost, finanční stabilita, hospodárnost

3. Př́stupy k řízení nákladů, výnosů, zisku a přidané hodnoty

a) Význam členění nákladů pro potřeby rozhodování

b) Výkonově orientované manažerské účetnictví a controlling

c) Odpovědnostně orientované manažerské účetnictví a controlling

Klíčová slova:

odpovědnostní středisko, oportunitní náklady, přidaná hodnota, rozdílové náklady, zpracovatelské řešení manažerského účetnictví

4. Využití kalkulačního systému v řízení podnikových procesů a výkonů

a) Principy alokace nákladů

b) Tradiční a pokročilé metody kalkulace

c) Kalkulace založené na vztahu k aktivitám

Klíčová slova:

Activity-Based Costing, retrográdní kalkulace, rozvrhová základna

5. Systém plánů a rozpočtů

a) Časové dimenze systému plánů a rozpočtů

b) Rozpočtová rozvaha, výsledovka a cash flow

c) Vnitropodnikové rozpočty

Klíčová slova:

rozpočtový cash flow, rozpočtová rozvaha, rozpočtová výsledovka, střediskový rozpočet režijních nákladů

6. Krátkodobá manažerská rozhodnutí a jejich hodnocení

a) Typy rozhodovacích úloh

b) Optimalizační úlohy, úlohy ke stanovení dolního limitu ceny

c) Rozhodnutí o vlastní výrobě nebo o nákupu externí dodávky

Klíčová slova:

Cost-Profit-Volume analýza, příspěvek $\mathrm{k}$ tržbám, příspěvek na úhradu fixních nákladů a tvorbu zisku 
7. Dlouhodobá manažerská rozhodnutí

a) Tradiční postupy hodnocení investičních přiležitostí

b) Pokročilé metody hodnocení investičních př́ležitostí

c) Vyjádření přínosů investičních projektů

\section{Klíčová slova:}

Čistá současná hodnota, index rentability, náklady kapitálu, nominální diskontní sazba

8. Cenová rozhodování

a) Určení ceny $v$ závislosti na reakci spotřebitele

b) Nákladově orientované metody tvorby cen

c) Cenová diferenciace a diskriminace

Klíčová slova:

implicitní pružnost poptávky, konkurenční situace na trhu, směrná cena

9. Přístupy k měření, řízení a hodnocení výkonnosti firmy

a) Měření a hodnocení vnitřní výkonnosti

b) Měření a hodnocení celkové finanční výkonnosti

c) Metody finanční analýzy

Klíčová slova:

ekonomická přidaná hodnota, finanční výkonnost, vnitropodnikový výsledek hospodaření

10. Přístupy $k$ ř́zení a hodnocení finanční stability firmy

a) Řízení pracovního kapitálu

b) Řízení likvidity

c) Řízení peněžních toků

Klíčová slova:

likvidita, monitoring pohledávek a závazků, pracovní kapitál, řízení peněžních toků

11. Strategicky orientované manažerské účetnictví, controlling a finanční rízení

a) Kalkulace cílových nákladů a životního cyklu

b) Řízení aktivit, činností a procesů

c) Strategické rízení vnitropodnikových útvarů

Klíčová slova:

Activity-Based Management, Value-Based Management, ekonomická přidaná hodnota

12. Vývojové tendence v ekonomickém a finančním řízení firmy.

a) Interdisciplinarita

b) Environmentální manažerské účetnictví

c) Společenská odpovědnost a udržitelný rozvoj

Klíčová slova:

environmentální náklady a výnosy, společenská návratnost investice, společenská odpovědnost

\section{LITERATURA}

\section{Základní:}

Petřík, T. (2009). Ekonomické a finanční řizení firmy. Manažerské účetnictví v praxi (2. vydání). Praha: Grada.

$\checkmark \quad$ Král, M. \& kol. (2010). Manažerské účetnictví (3. vydání). Praha: Management Press.

$\checkmark$ Eschenbach, R. (2010). Controlling (3. vydání). Praha: ASPI Publishing. 


\section{Doporučená:}

$\checkmark$ Dvořáková, L., Červený, J., Malá, A. \& Kronych, J. (2017). Manažerské účetnictví a controlling $v$ praktických aplikacích. Plzeň: Nava.

$\checkmark$ Drury, C. (2008). Management and Cost Accounting ( $7^{\text {th }}$ edition). London: Thomson Learning.

$\checkmark$ Crosson, S. V. \& Needles, B. E. (2014). Managerial accounting (10 ${ }^{\text {th }}$ edition). Mason, USA: South-Western Cengage Learning.

\section{POŽADAVKY NA STUDENTA}

1. Zvládnout předmět $v$ rozsahu stanoveném sylabem a prokázat vědomosti a dovednosti při ústní zkoušce, písemnou prací (výzkumná orientace práce) a její obhajobou s prezentací.

2. Nastudovat samostatně doporučené literární zdroje.

3. Zpracovat písemnou práci (výzkumnou esej) na vybrané téma z oblasti ekonomického a finančního řízení firmy. Vybrané téma a zaměření výzkumné eseje předem konzultovat s garantem předmětu. Rozsah výzkumné eseje minimálně 25 - 30 stránek $A 4$.

4. Odevzdat finální verzi písemné práce (výzkumné eseje) v tištěné formě nejméně jeden týden před závěrečnou konzultací s garantem předmětu k výsledku písemné práce.

5. Prokázat získané znalosti, vědomosti a dovednosti při ústní zkoušce, která se skládá z finální prezentace a diskuse výsledků výzkumné eseje a kontrolních otázek v rozsahu témat stanovených sylabem předmětu.

\section{FORMA A ROZSAH VÝUKY}

Výuka předmětu probihá formou blokové prezenční výuky (30 hodin) a individuálních konzultací s garantem predmětu.

1. Obsah 1. výukového bloku, rozsah 6 hodin

a) Druhy účetních systémů

b) Manažerské účetnictví a controlling - definice, cíle, aspekty

c) Metody a nástroje manažerského účetnictví a controllingu

d) Kritéria finanční výkonnosti

e) Kritéria finanční stability

f) Finanční, hodnotové a ekonomické pojetí nákladů

2. Obsah 2. výukového bloku, rozsah 6 hodin

a) Význam členění nákladů pro potřeby rozhodování

b) Výkonově orientované manažerské účetnictví a controlling

c) Odpovědnostně orientované manažerské účetnictví a controlling

d) Principy alokace nákladů

e) Tradiční a pokročilé metody kalkulace

f) Kalkulace založené na vztahu k aktivitám

3. Obsah 3. výukového bloku, rozsah 6 hodin

a) Časové dimenze systému plánů a rozpočtů

b) Rozpočtová rozvaha, výsledovka a cash flow

c) Vnitropodnikové rozpočty

d) Typy rozhodovacích úloh

e) Optimalizační úlohy, úlohy ke stanovení dolního limitu ceny

f) Rozhodnutí o vlastní výrobě nebo o nákupu externí dodávky 
4. Obsah 4. výukového bloku, rozsah 6 hodin

a) Tradiční postupy hodnocení investičních přiležitostí

b) Pokročilé metody hodnocení investičních příležitostí

c) Vyjádření prínosů investičních projektů

d) Určení ceny $v$ závislosti na reakci spotřebitele

e) Nákladově orientované metody tvorby cen

f) Cenová diferenciace a diskriminace

5. Obsah 5. výukového bloku, rozsah 6 hodin

a) Přístupy k měření, řízení a hodnocení výkonnosti firmy

b) Přístupy k řízení a hodnocení finanční stability firmy

c) Strategicky orientované manažerské účetnictví a controlling

d) Vývojové tendence $v$ ekonomickém a finančním řízení firmy

\section{DALŠÍ INFORMACE GARANTA PŘEDMĚTU}

\section{KONTAKT NA GARANTA PŘEDMĚTU}

\begin{tabular}{|l|l|}
\hline E-mail: & Idvorako@kfu.zcu.cz \\
\hline Telefon: & +420377633207 \\
\hline Konzultační hodiny: & (dle aktuálního zadání na www.fek.zcu.cz) \\
\hline Kancelář: & UK 514, FEK ZČU, Univerzitní 22, 306 14 Plzeň \\
\hline
\end{tabular}




\section{Strategický marketing firmy}

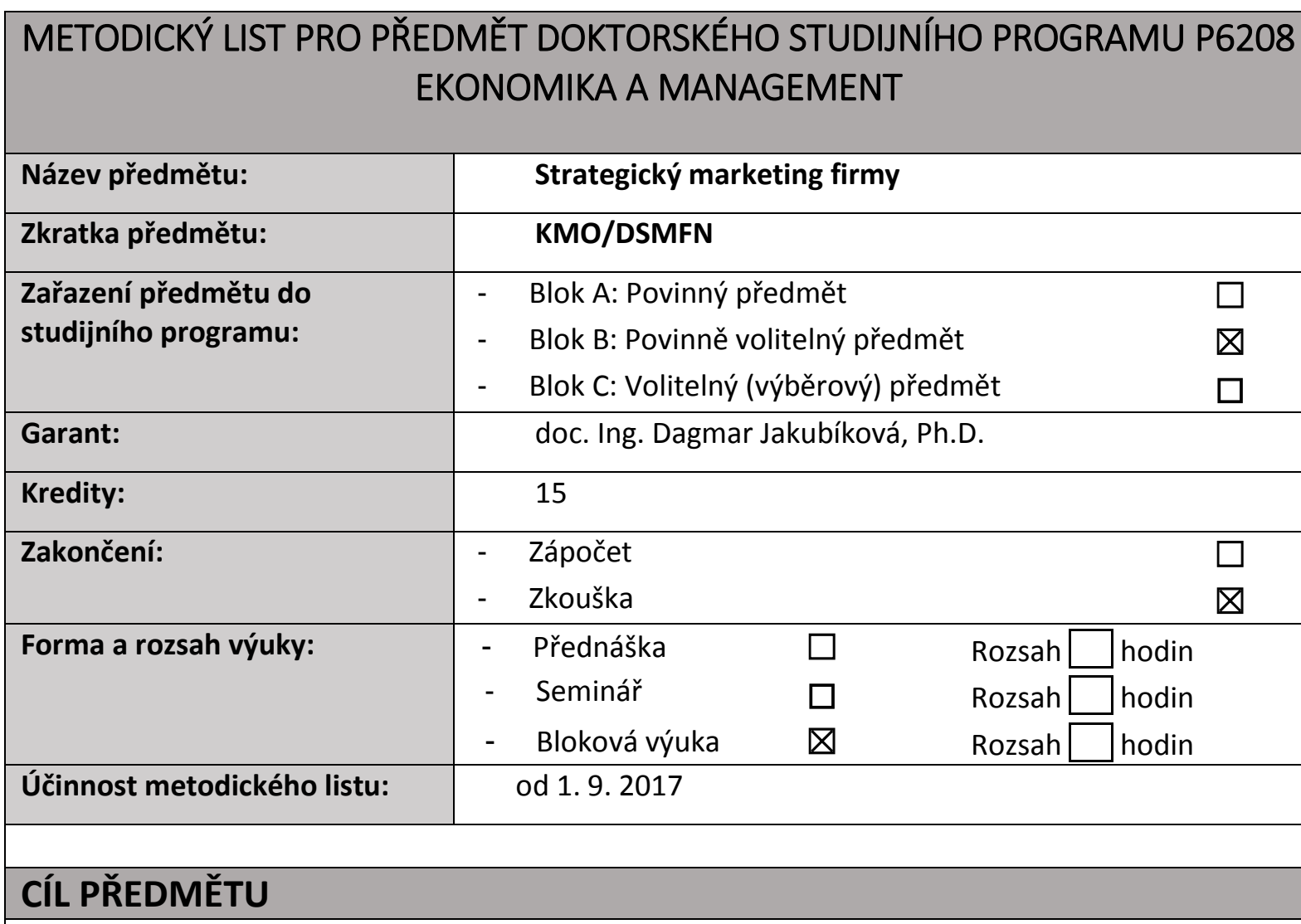

Seznámit s podstatou a metodami strategického marketingu s praktickým zaměřením zejména na obchodní firmy. Vysvětlit problematiku tvorby marketingového strategického plánu firmy, seznámit s metodami kontroly plnění tohoto plánu. Naučit studenty orientovat se $v$ problematice tvorby marketingových strategií v mezních podnikatelských situacích a osvojit si metody výzkumu trhu.

\section{OBSAH PŘEDMĚTU}

1. Strategické řízení firem a organizací - limitující faktor marketingového procesu

2. Hodnocení tržní výkonnosti podniku

3. Strategický marketingový proces: plánování, realizace, kontrola

4. Základní a specifické metody marketingové situační analýzy

5. Marketingový informační systém, marketingový výzkum, PIMS program

6. Strategické marketingové cíle, proces prípravy marketingových strategií

7. Marketingové strategie

8. Marketingové strategie $v$ oblasti jednotlivých prvků marketingového mixu

9. Implementace marketingových strategií a organizace marketingu ve firmě

10. Kontrola a marketingový audit

11. Specifika tvorby marketingové strategie na mezinárodních trzích

12. Marketingové strategie v mezních podnikatelských situacích 


\section{OBSAH PŘEDMĚTU S DALŠÍ SPECIFIKACÍ}

1. Strategické řízení firem a organizací - limitující faktor marketingového procesu

a) Podstata podnikání a úloha strategické řízení firem a organizací

b) Strategická východiska, vzájemné vazby strategického řízení a strategického marketingu

c) Vývoj marketingu a podnikatelských koncepcí v čase

\section{Klíčová slova:}

marketing, podnikání, strategický marketing, strategické rízení

2. Hodnocení tržní výkonnosti podniku

a) Analýza celkové finanční výkonnosti podniku

b) Fundamentální (kvalitativní) ekonomická analýza

c) Specifické nástroje fundamentální analýzy

\section{Klíčová slova:}

analýza hodnoty pro zákazníka, ekonomická analýza, finanční výkonnost, metoda kritických faktorů úspěšnosti

3. Strategický marketingový proces: plánování, realizace, kontrola

a) Proces marketingového strategického projektování a strategický marketingový plán

b) Předpoklady úspěšné realizace strategického plánu

c) Typy marketingové kontroly

\section{Klíčová slova:}

OSCAR, podnikové a marketingové cíle, strategické analýzy, strategické rozpočtování

4. Základní a specifické metody marketingové situační analýzy

a) Situační analýza a predikce vývoje prostředí

b) Portfolio analýzy a jejich modifikace

c) Specifické metody marketingové situační analýzy

\section{Klíčová slova:}

analýza složek prostředí podniku, portfolio matice, strategické skupiny, tržní mezery

5. Marketingový informační systém, marketingový výzkum, PIMS program

a) Důležitost informací a okruhy informačních potřeb úspěšného podniku

b) MIS - marketingový informační systém, marketingový výzkum a marketingové zpravodajství

c) PIMS (profit impact of market strategy) program

Klíčová slova:

MIS, marketingový výzkum, marketingové zpravodajství, PIMS program

6. Strategické marketingové cíle, proces prípravy marketingových strategií

a) Cílové trhy, proces výběru cílových trhů (segmentace trhu, volba cílového trhu, stanovení pozice) a cílový marketing

b) Formulace a volba strategických marketingových cílů

c) Proces přípravy marketingových strategií

Klíčová slova:

cílové priority a priority marketingového mixu, kvantitativní a kvalitativní dimenze trhů, metody scénáře a strategické projekce, trh a segmentace trhu, 
7. Marketingové strategie

a) Systemizace marketingových strategií - marketingové strategie parciální a integrované strategie; strategie zaměřené na trh a strategie zaměřené na konkurenci, ...

b) Strategie modrého oceánu

c) Vyhodnocování marketingových strategií

Klíčová slova:

implementace marketingové strategie, marketingová strategie, vyhodnocování strategií, efektivnost a spolehlivost

8. Marketingové strategie $v$ oblasti jednotlivých prvků marketingového mixu

a) Marketingový mix v pojetí různých autorů

b) Strategie v oblasti základních prvků marketingového mixu - produktová, cenová, distribuční a komunikační strategie

c) Strategie v oblasti prvků rozšířeného marketingového mixu

Klíčová slova:

CRM, hodnota - produktu a zákazníka, marketingový mix, trh

9. Implementace marketingových strategií a organizace marketingu ve firmě
a) Předpoklady úspěšné implementace marketingových strategií
b) Strategicky orientovaná firemní kultura
c) Organizace marketingu ve firmě

Klíčová slova:

marketingová strategie, marketingově orientovaná firemní kultura, podniková organizační struktura

10. Marketingová kontrola a marketingový audit
a) Marketingová kontrola a typy marketingové kontroly
b) Hodnocení marketingu
c) Marketingový audit

Klíčová slova:

analýza prodeje, tržního podílu, nákladů a rentability marketingu, marketingový audit, marketingová kontrola

11. Specifika tvorby marketingové strategie na mezinárodních trzích

a) Marketing a mezinárodní podnikání

b) Růstové strategie $v$ mezinárodním prostředí a strategie $v$ oblasti základních prvků marketingového mixu

c) Marketingové strategie na globálních trzích

Klíčová slova:

globalizace, marketingové strategie, mezinárodní trhy, strategické plánování

12. Marketingové strategie $v$ mezních podnikatelských situacích

a) Identifikace možných mezních podnikatelských situací při zahájení podnikání, restrukturalizaci podniku, při vyhledávání strategického partnera, při prodeji firmy, ...

b) Marketingové strategie $v$ mezních podnikatelských situacích

c) Firemní a etické hodnoty

Klíčová slova:

etické hodnoty, hodnota firmy, marketingové strategie, mezní podnikatelské situace 


\section{LITERATURA}

\section{Základní:}

Jakubíková, D. (2013). Strategický marketing: strategie a trendy (2. rozšířené vydání). Praha: Grada Publishing.

$\checkmark \quad$ Kotler, P. \& Keller, K. L. (2013) Marketing management (14. vydání). Praha: Grada Publishing.

$\checkmark$ Machková, H. (2015). Mezinárodní marketing: strategické trendy a príklady z praxe (4. vydání). Praha: Grada Publishing.

\section{Doporučená:}

$\checkmark$ Cravens, D. \& Piercy, N. (2012). Strategic Marketing (10 ${ }^{\text {th }}$ edition). McGraw-Hill/Irwin.

$\checkmark$ Dawar, N. (2013). Shifting Your Strategy from Products to Customers. Boston: Harward Business Review Press.

$\checkmark$ Horáková, H. (2014) Marketingové strategie. Praha: IDEA SERVIS.

$\checkmark$ Kumar, N. (2008). Marketing jako strategie vedoucí k úspěchu (1. vydání). Praha: Grada Publishing.

$\checkmark$ Macbeth, D. K. (2015) Strategic Analysis of Supply Chain Design (1 ${ }^{\text {th }}$ edition) Southampton (UK): Univerzity of Southampton Business School.

$\checkmark$ Smrčka, L., Plaček, J. (2015). Company Control and Takeovers as a Growth Strategy. Oxford: Oxford Tutorials.

$\checkmark$ Souček, Z. (2015). Strategie úspěšného podniku: symbióza kreativity a disciplíny. Praha: C. H. Beck.

\section{POŽADAVKY NA STUDENTA}

1. Zvládnout předmět $v$ rozsahu stanoveném sylabem a prokázat vědomosti a dovednosti při ústní zkoušce, písemnou prací (výzkumná orientace práce) a její obhajobou s prezentací.

2. Nastudovat samostatně doporučené literární zdroje.

3. Zpracovat písemnou práci (výzkumnou esej) na vybrané téma z oblasti strategického marketingu firmy. Vybrané téma předem konzultovat s garantem předmětu. Rozsah výzkumné eseje minimálně 25 - 30 stránek A4.

4. Odevzdat finální verzi písemné práce (výzkumné eseje) v tištěné formě nejméně dva týdny před závěrečnou konzultací s garantem předmětu k výsledku písemné práce.

5. Prokázat získané znalosti, vědomosti a dovednosti při ústní zkoušce, která se skládá z finální prezentace a diskuse výsledků výzkumné eseje a kontrolních otázek v rozsahu témat stanovených sylabem předmětu.

\section{FORMA A ROZSAH VÝUKY}

Výuka předmětu probíhá formou samostudia a individuálních konzultací s garantem předmětu.

\section{DALŠÍ INFORMACE GARANTA PŘEDMĚTU}




\section{KONTAKT NA GARANTA PŘEDMĚTU}

\begin{tabular}{|l|l|}
\hline E-mail: & dagmar.jakubikova@seznam.cz \\
\hline Telefon: & +420606215556 \\
\hline Konzultační hodiny: & (dle individuální dohody s garantem předmětu) \\
\hline Kancelár̆: & UK 526, Univerzitní 22, 306 14 Plzeň \\
& CD 207, Hradební 22, Cheb \\
\hline
\end{tabular}


Kvantitativní metody v ekonomii

\section{METODICKÝ LIST PRO PŘEDMĚT DOKTORSKÉHO STUDIJNÍHO PROGRAMU P6208 EKONOMIKA A MANAGEMENT}

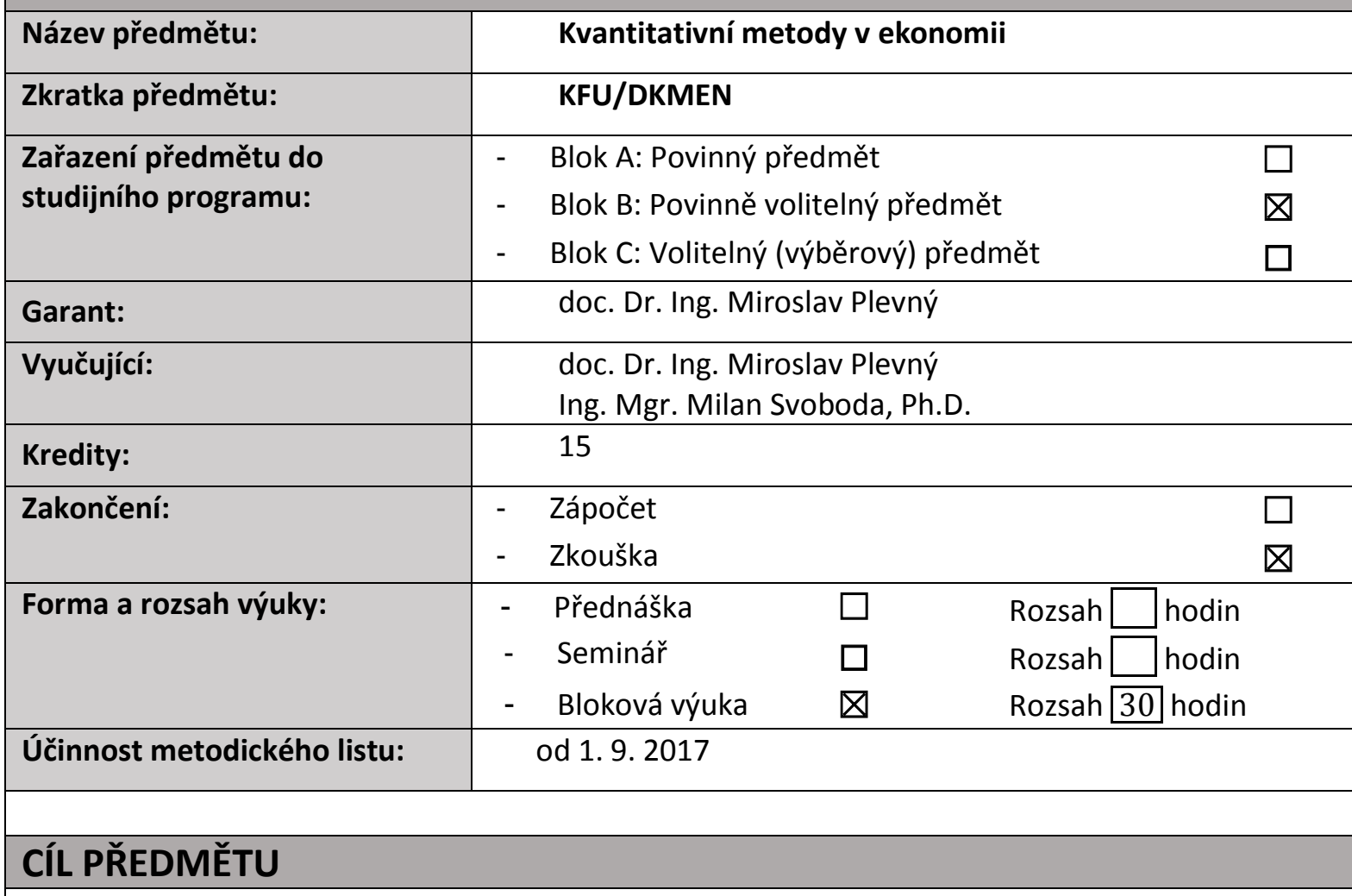

Poskytnout hlubší znalosti o statistických metodách, metodách operačního výzkumu a jiných exaktních metodách aplikovatelných pro kvantitativní analýzu problémů a pro rídicí a rozhodovací procesy v podnicích. Podat přehled o možnostech využití těchto metod v odborné práci.

\section{OBSAH PŘEDMĚTU}

1. Statistické metody:

- Metody pořizování dat, datová matice

- Vícerozměrné metody statistické analýzy dat, jejich přehled

- Vícenásobná lineární regrese

- Logistická regrese

- Ekonomické časové řady, jejich klasifikace

- Dekompozice časové řady

- Boxova - Jenkinsonova metodologie

2. Metody operačního výzkumu:

- Matematické programování

- Teorie grafů a sítová analýza

- Modely ř́zení zásob

- Teorie hromadné obsluhy

- Teorie her a teorie rozhodování 
- Teorie obnovy

- Možnosti aplikací a aplikabilita těchto metod

\section{OBSAH PŘEDMĚTU S DALŠÍ SPECIFIKACÍ}

1. Data

a) Metody pořizování dat

b) Datová matice

c) Ověřování kvality dat

Klíčová slova:

data, datová matice, proměnné, odlehlá pozorovaní, chybějící údaje, testy rozdělení

2. Vícerozměrné statistické metody

a) Přehled vybraných metod

b) Klasifikace metod a volba metody

c) Použitelnost metod

Klíčová slova:

vícerozměrné metody, klasifikace, kovariační matice, analýza

3. Regresní analýza

a) Vícenásobná lineární regrese

b) Obecný lineární model

c) Logistická regrese

Klíčová slova:

regrese, vysvětlované a vysvětlující proměnné, index determinace, korelace, předpověd'

4. Dekompozice časové řady

a) Složky časové řady

b) Modely trendové složky

c) Modely sezonní složky

Klíčová slova:

složky časové řady, trend, sezónnost, předpověd'

5. Boxova - Jenkinsonova metodologie (BJM)

a) Základní pojmy a aparát v BJM

b) Výstavba modelů v BJM

c) Další možnosti BJM

Klíčová slova:

korelace, stacionarita, autoregresní proces, proces klouzavých průměrů, předpověd'

6. Matematické programování

a) Lineární a celočíselné programování

b) Nelineární programování

c) Metody řešení matematických modelů

Klíčová slova:

simplexová metoda, metoda větví a hranic, gradientové metody 
7. Teorie grafů a sítová analýza

a) Grafy a optimalizační problémy na grafech

b) Sítový graf jako model projektu

c) Metody časové a nákladové analýzy projektů

Klíčová slova:

graf, optimalizační úlohy na grafech, CPM, PERT, nákladová křivka

8. Modely řízení zásob

a) Deterministické modely řízení zásob

b) Pravděpodobnostní modely řízení zásob

Klíčová slova:

zásoby, náklady související se zásobami, nedostatek zásob, náhodná poptávka, výkyvy v dodávkách

9. Teorie hromadné obsluhy

a) Systémy hromadné obsluhy (SHO)

b) Analytické postupy řešení SHO

c) Řešení SHO pomocí simulace

Klíčová slova:

paralelní SHO, charakteristiky SHO, simulace

10. Teorie her a teorie rozhodování

a) Hry dvou hráčů

b) Hry více hráčů

c) Rozhodování za jistoty, rizika a nejistoty

\section{Klíčová slova:}

maticové hry, strategie hráčů, vícekriteriální optimalizační model, vícekriteriální analýza variant

11. Teorie obnovy

a) Údržba a obnova

b) Procesy obnovy

c) Optimální cyklus obnovy

Klíčová slova:

doba životnosti, pravděpodobnost selhání, rovnice obnovy

\section{LITERATURA}

\section{Základní:}

$\checkmark$ Arlt, J. \& Arltová, M. (2009). Ekonomické časové řady. Praha: Professional Publishing.

$\checkmark$ Hebák, P. \& kol. (2013) Statistické myšlení a nástroje analýzy dat. (1. vydání). Praha: Informatorium.

$\checkmark$ Plevný, M. \& Žižka, M. (2010) Modelování a optimalizace v manažerském rozhodování. (2. vydání). Plzeň: Západočeská univerzita.

$\checkmark$ Dlouhý, M. \& Fiala P. (2015) Teorie ekonomických a politických her. Praha: Oeconomica.

\section{Doporučená:}

Anderson, D. R. (2008). An introduction to management science: quantitative approaches to decision making. (12 ${ }^{\text {th }}$ edition). Mason: Thomson/South-Western.

$\checkmark$ Box, G. E. P., Jenkins, G. M. \& Reinsel, G. C. (2008). Time Series Analysis: Forecasting and Control. ( $4^{\text {th }}$ edition). Hoboken: John Wiley \& Sons. 
Hair, J. F., Black, W. C., Babin, B. J. \& Anderson E. Rolph. (2014). Multivariate Data Analysis. ( $7^{\text {th }}$ edition). Harlow: Pearson.

$\checkmark$ Render, B., Hanna, M. E. \& Stair, R. M. (2003) Quantitative analysis for management. Upper Saddle River: Prentice Hall.

\section{POŽADAVKY NA STUDENTA}

1. Aktivní účast minimálně na čtyřech blocích výuky, samostudium doporučených zdrojů.

2. Zpracování semestrální práce: zadání je dle zaměření doktoranda (rozsah práce 20 - 30 normostran).

3. Složení závěrečné zkoušky. Zkouška je podmíněna úspěšnou obhajobou výše zmíněné semestrální práce a prokázáním dostatečných znalostí z okruhů uvedených v obsahu předmětu.

\section{FORMA A ROZSAH VÝUKY}

Výuka předmětu probíhá formou blokové prezenční výuky (30 hodin) a individuálních konzultací s garantem předmětu.

1. Obsah 1. výukového bloku, rozsah 6 hodin

a) Metody sběru dat, datová matice

b) Přehled vybraných vícerozměrných metod

c) Použitelnost metod pro různé typy úloh

d) Vícenásobná lineární regrese

e) Obecný lineární model

f) Logistická regrese

2. Obsah 2. výukového bloku, rozsah 6 hodin
a) Klasifikace časových řad
b) Základní prístupy k analýze časových řad
c) Dekompozice časových řad
d) Modelování trendu a sezónní složky
e) Boxova - Jenkinsonova metodologie (BJM)
f) Výstavba modelů v BJM

3. Obsah 3. výukového bloku, rozsah 6 hodin
a) Matematické modelování
b) Řešitelnost matematických modelů
c) Metody řešení LP, CLP a NLP modelů
d) Moderní techniky řešení matematických modelů
e) Analýza citlivosti a dualita LP modelů

4. Obsah 4. výukového bloku, rozsah 6 hodin
a) Pojmy teorie grafů
b) Optimalizační problémy na grafech
c) Metody analýzy projektu podle jednotlivých hledisek
d) Zásoby, náklady související s rízením zásob
e) Deterministické modely řízení zásob a jejich řešení
f) Stochastické modely řízení zásob, stanovení pojistné zásoby 
5. Obsah 5. výukového bloku, rozsah 6 hodin

a) Vstupní a sledované charakteristiky systémů hromadné obsluhy

b) Řešení systémů hromadné obsluhy - analytické, pomocí simulace

c) Hry dvou a více hráčů, strategie her

d) Rozhodování za jistoty, rizika a nejistoty

e) Problémy údržby a obnovy z nákladového hlediska

f) optimalizace procesu obnovy

\section{DALŠí INFORMACE GARANTA PŘEDMĚTU}

Termíny blokové výuky budou stanovovány po vzájemné dohodě studentů a vyučujících.

\section{KONTAKT NA GARANTA PŘEDMĚTU}

\begin{tabular}{|l|l|}
\hline E-mail: & plevny@kem.zcu.cz \\
\hline Telefon: & 377633501 \\
\hline Konzultační hodiny: & (dle aktuálního zadání na www.fek.zcu.cz) \\
\hline Kancelář: & UK 421, FEK ZČU, Univerzitní 22, 306 14 Plzeň \\
& CD 301, FEK ZČU, Hradební 22, 350 11 Cheb \\
\hline
\end{tabular}


Zahraniční stáž

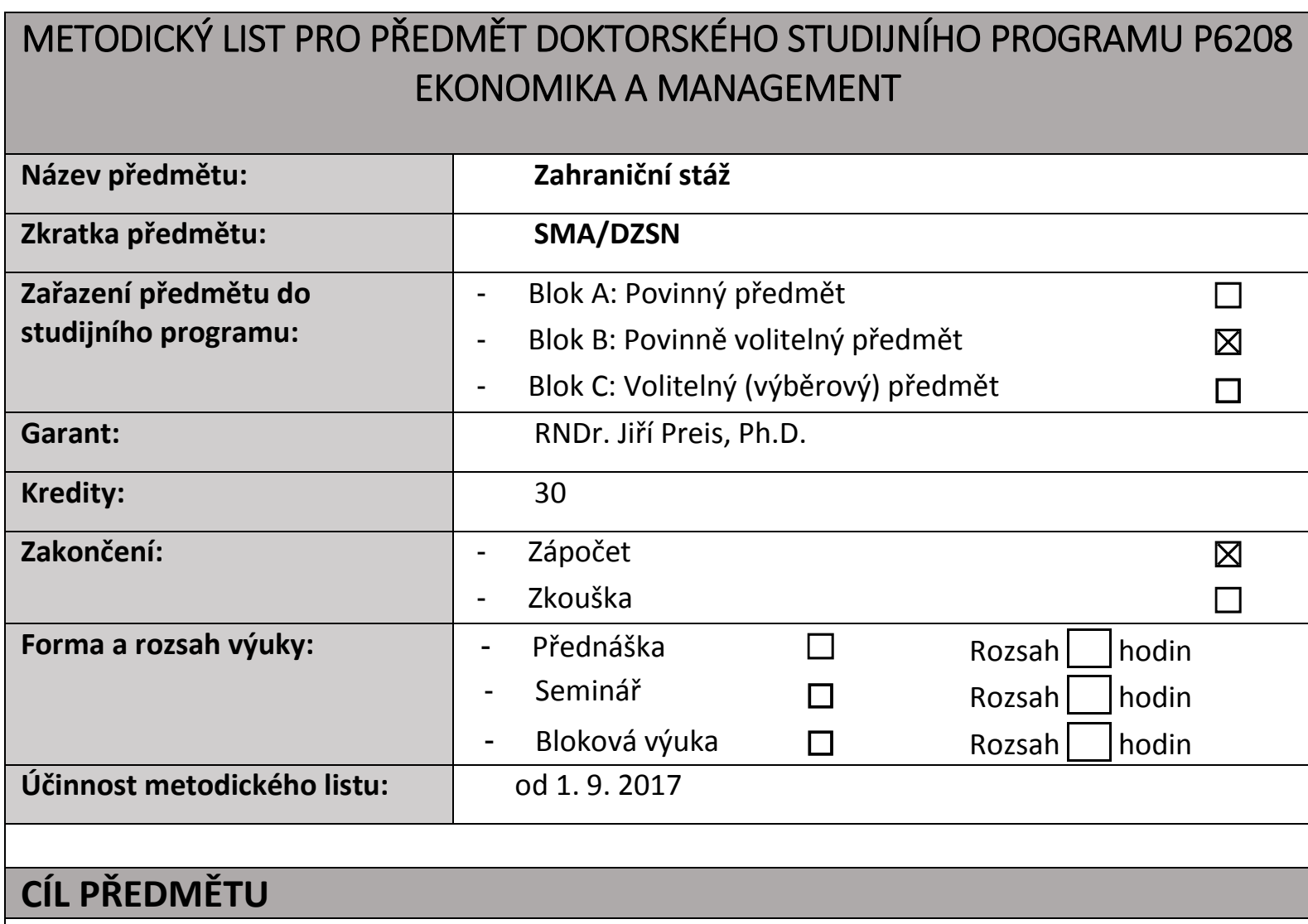

Vytvořit si portfolio kontaktů na zahraniční odborníky; podílet se na výzkumu na zahraniční partnerské instituci; pracovat $v$ zahraničním týmu; aplikovat získané zkušenosti na domácím pracovišti a ve vlastní profesní kariéře.

\section{OBSAH PŘEDMĚTU}

1. Teoretická i praktická příprava před odjezdem: komunikace s partnerským pracovištěm, příprava materiálů a hrubého rozvrhu pro pobyt a náplň jednotlivých dnů/týdnů; vyřízení nezbytných záležitostí (pojištění, ubytování, doprava)

2. Odjezd a samotná realizace stáže

3. Shrnutí aktivit a výsledků stáže po návratu formou diskuse, kolokvia; sepsání závěrečné zprávy; vyúčtování (v př́ípadě kofinancování grantem Erasmus+, FreeMovers)

4. Sebehodnocení prínosů absolvované stáže, plán pro aplikaci zkušeností/dovedností/kontaktů na domácím pracovišti

\section{OBSAH PŘEDMĚTU S DALŠÍ SPECIFIKACÍ}

$\checkmark \quad$ Bez bližší specifikace. 


\section{LITERATURA}

Základní:

\section{Doporučená:}

$\checkmark \quad$ Definition and Benefits of an Internship. Retrieved August 9, 2017 from Pomerantz Career Center for Leadership and Career Advancement, University of lowa website, https://careers.uiowa.edu/students/benefits-internship

$\checkmark$ Směrnice č. 3DS/2014 děkana Fakulty ekonomické ZČU "Organizace studia v doktorském studijním programu" s upřesněním po reakreditaci oboru. Plzeň: FEK ZČU.

\section{POŽADAVKY NA STUDENTA}

1. Znalost světového jazyka minimálně na úrovni $\mathrm{C} 1$.

2. Vlastní výzkumný projekt.

3. Schopnost mezikulturní komunikace a práce v prostřední s odlišnou kulturou.

4. Schopnost přednášet/referovat o svém výzkumu v cizím jazyce před zahraničním publikem.

\section{FORMA A ROZSAH VÝUKY}

Výuka předmětu neprobíhá formou blokové ani kontaktní prezenční výuky. Více informací viz „DALŠÍ INFORMACE GARANTA PŘEDMĚTU“.

\section{DALŠÍ INFORMACE GARANTA PŘEDMĚTU}

Zahraniční stáž je specifickým předmětem, při němž neprobíhá kontaktní ani bloková výuka.

Student si se svým školitelem připraví výzkumný projekt, který bude během zahraniční stáže realizovat. S garantem předmětu pak student $v$ př́pravné fázi konzultuje praktické věci týkající se realizace praxe, její náplň a samotný průběh, a také aktivity po návratu ze stáže.

Po absolvování stáže student s garantem předmětu prodiskutuje celkovou zpětnou vazbu a rovněž možnou aplikaci znalostí a dovedností získané během pobytu. Rovněž s ním projde a zhodnotí závěrečnou zprávu s dokladem o úspěšném absolvování stáže od kontaktní osoby na zahraniční instituci, kterou student sepíše.

Za úspěšné splnění předmětu se považuje splnění cílů stáže, sepsání závěrečné, ústní zhodnocení prínosů pobytu na zahraničním pracovišti a plán na jejich další využití na domovském pracovišti.

\section{KONTAKT NA GARANTA PŘEDMĚTU}

\begin{tabular}{|l|l|}
\hline E-mail: & jpreis@kge.zcu.cz \\
\hline Telefon: & 377633067 \\
\hline Konzultační hodiny: & (dle aktuálního zadání na www.fek.zcu.cz) \\
\hline Kanceláŕ: & UK 525, FEK ZČU, Univerzitní 22, 306 14 Plzeň \\
\hline
\end{tabular}




\section{KAPITOLA 3}

\section{Výběrové předměty}

\begin{tabular}{|l|c|c|c|c|c|}
\hline \multicolumn{1}{|c|}{ Název předmětu } & $\begin{array}{c}\text { Zkratka } \\
\text { předmětu }\end{array}$ & $\begin{array}{c}\text { Počet } \\
\text { kreditů }\end{array}$ & $\begin{array}{c}\text { Zakončeno } \\
\text { (Zp/ Zk) }\end{array}$ & \multicolumn{2}{c|}{ Doporučeno } \\
\cline { 4 - 6 } & KPM/DPMN & 10 & Zk & 3 & ZS/LS \\
\hline Projektový management & KMO/DMLSN & 10 & Zk & 3 & ZS/LS \\
\hline $\begin{array}{l}\text { Management logistických } \\
\text { systémů }\end{array}$ & KEM/DSSN & 10 & Zk & - & ZS/LS \\
\hline $\begin{array}{l}\text { Metody a systémy pro podporu } \\
\text { rozhodování }\end{array}$ & KMO/DKSVN & 10 & Zk & - & ZS/LS \\
\hline $\begin{array}{l}\text { Kvalitativní a smíšený výzkum } \\
\text { v ekonomii }\end{array}$ & KPV/DPISN & 10 & Zk & - & ZS/LS \\
\hline $\begin{array}{l}\text { Podnikové informační systémy } \\
\text { Kooperace v mezinárodním } \\
\text { vědeckém týmu }\end{array}$ & FEK/DKON & 10 & Zp & - & ZS/LS \\
\hline $\begin{array}{l}\text { Celkem výběrové předměty za } \\
\text { celé studium }\end{array}$ & - & $\mathbf{2 0}$ & - & - & - \\
\hline
\end{tabular}

\section{Poznámka:}

Dalšími výběrovými předměty mohou být předměty z bloku povinně volitelných předmětů nebo predměty ostatních fakult ZČU. 
Projektový management

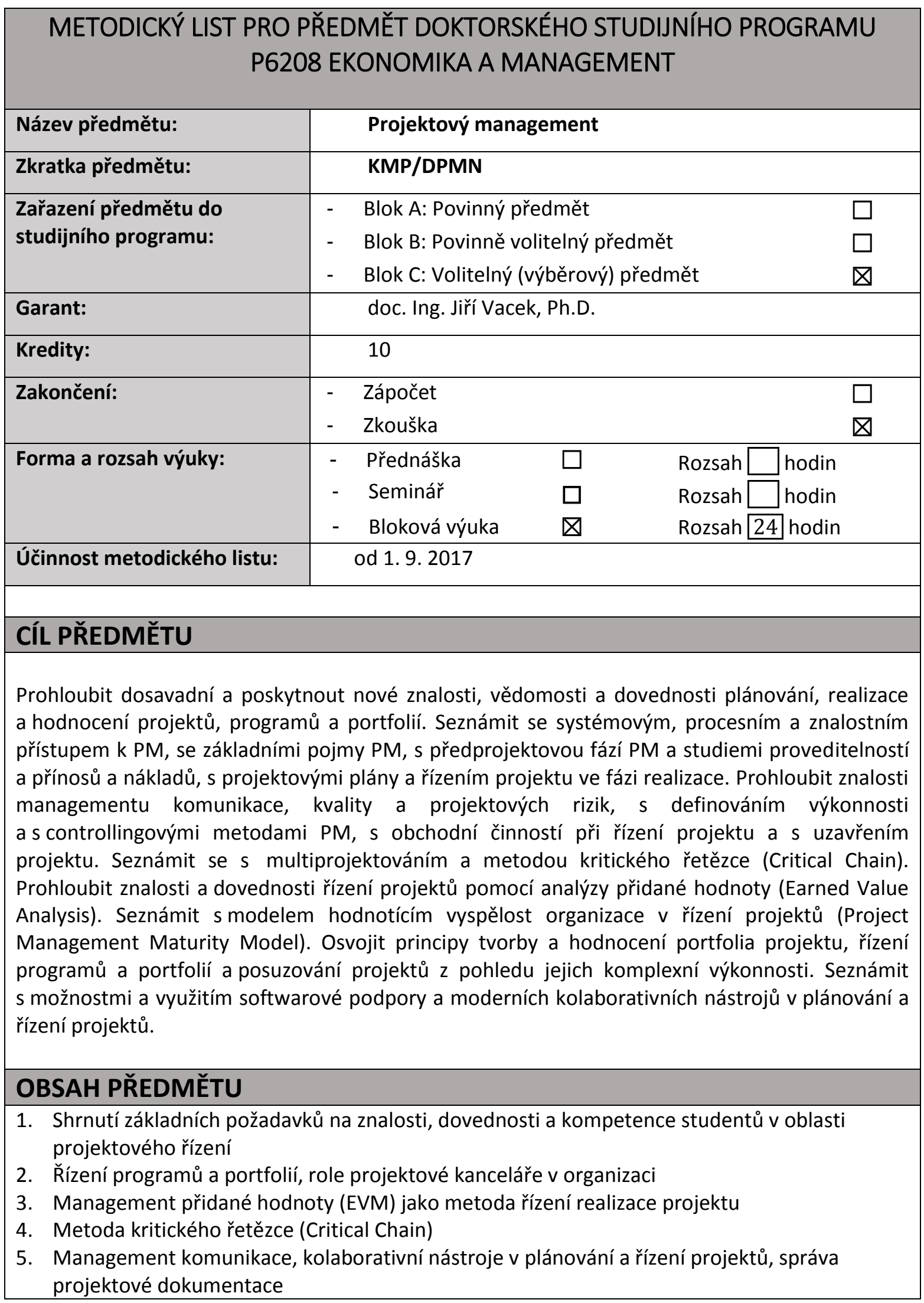


6. Management rizik

7. Studie př́ležitosti, analýza př́nosů a nákladů (CBA)

8. Kvalita v projektovém řízení a metoda Project Balanced Scorecard

9. Agilní projektový management

10. Finanční rízení projektů, programů a portfolií

11. Management obchodních činností

12. Př́padové studie, príklady dobré praxe

\section{OBSAH PŘEDMĚTU S DALŠÍ SPECIFIKACÍ}

1. Shrnutí základních požadavků na znalosti, dovednosti a kompetence studentů voblasti projektového řízení

a) Historie a základy projektového řízení

b) Plánování projektu - projektový trojúhelník, logický rámec, stakeholdeři, plán komunikace, rizik, kvality

c) Řízení, monitorování a hodnocení průběhu projektu - Ganttův diagram, kritická cesta, zdroje a rozpočet

d) Softwarová podpora projektového managementu

Klíčová slova:

projekt, plánování projektu, řizení projektu, softwarová podpora plánování

2. Řízení programů a portfolií, role projektové kanceláře v organizaci

a) Cíle tvorby programů a portfolií

b) Hodnocení projektů a jejich výběr

c) Multiprojektování, řešení konfliktů požadavků

d) Role projektové kanceláře

Klíčová slova:

hodnocení projektů, multiprojektování, program a portfolio projektů, projektová kancelár̆

3. Management prídané hodnoty (EVM) jako metoda řízení realizace projektu.

a) Použitelnost EVM pro plánování a sledování projektu

b) Indikátory průběhu projektu

c) Softwarová podpora EVM

Klíčová slova:

indikátory průběhu projektu, management přidané hodnoty (EVM), monitorování projektu

4. Metoda kritického řetězce (Critical Chain)

a) Kritický řetězec jako nástroj zvýšení úspěšnosti projektu

b) Zásobník rezerv, jeho tvorba a využití

Klíčová slova:

kritický řetězec, práce s rezervami

5. Management komunikace, kolaborativní nástroje v plánování a rízení projektů, správa projektové dokumentace

a) Komunikace jako jedna ze základních kompetencí projektového manažera

b) Stakeholdeři

c) Kolaborativní nástroje a jejich využití

d) Správa projektové dokumentace - řízená dokumentace, procesy správy dokumentů, životní cyklus dokumentu, verzování, archiv dokumentů. 
Klíčová slova:

kolaborativní nástroje, komunikace; správa dokumentů, stakeholdeři

6. Řízení rizik

a) Identifikace rizik, hodnocení závažnosti

b) Nápravná opatření (preventivní, následná)

c) Spouštěče a vlastníci rizik

d) Registr rizik

Klíčová slova:

nápravná opatření, registr rizik, rizika projektů

7. Analýza prínosů a nákladů

a) Studie proveditelnosti a analýza prínosů a nákladů

b) Hodnocení proveditelnosti podnikatelských a veřejných projektů

c) Finanční a nefinanční přínosy projektů

Klíčová slova:

podnikatelské a veřejné projekty, proveditelnost, přínosy a náklady

8. Kvalita v projektovém řízení a metoda Project Balanced Scorecard

a) Kvalita projektu a projektového produktu

b) Model vyspělosti projektového rrízení (Project Management Maturity Model)

c) Stupeň vyspělosti instituce v ř́zení projektů

Klíčová slova:

kvalita projektu, kvalita projektového produktu, vyspělost projektového řizení

9. Agilní projektový management

a) Důvody vzniku agilního projektového managementu

b) Základní principy a postupy agilního PM

c) Rozdíly mezi tradičním (vodopádovým) a agilním přistupem

Klíčová slova:

agilní projektový management, postupy agilního PM, vodopádové rízení projektu

10. Komplexní hodnocení projektů

a) NPV, IRR, EVA

b) Balanced Scorecard (BSC)

c) EFQM

d) Project Management Performance Assessment Model (PMPA)

e) Project Management Balanced Scorecard

Klíčová slova:

BSC, EFQM, PMBSC, PMPA

11. Management obchodních činností.

a) Smluvní zajištění zahájení a ukončení projektu

b) Výběr dodavatelů a partnerů podle strategické důležitosti komodit a schopností dodavatelů

c) Výběrová řízení

d)

Klíčová slova:

smluvní zajištění projektů, výběr dodavatelů a partnerů, výběrová řízení 
12. Př́padové studie, príílady dobré praxe

Klíčová slova:

príklady dobré praxe, př́padové studie

\section{LITERATURA}

\section{Základní:}

$\checkmark$ Crawford, K. J. (2015). Project Management Maturity Model ( $3^{\text {rd }}$ edition). Boca Raton, FL: CRC Press, Taylor \& Francis Group.

$\checkmark$ DOLEŽAL, J. a.-8.-2.-2.-3. (2009). Projektový management podle IPMA.

$\checkmark$ Fleming, Q. W. \& Koppelman, J. M. (2010). Earned value : project management. ( $4^{\text {th }}$ edition). Newtown Squar: Project Management Institute.

$\checkmark$ Kerzner, H. (2017). Project Management: A Systems Approach to Planning, Scheduling, and Controlling (12 ${ }^{\text {th }}$ edition). New York: John Wiley \& Sons.

$\checkmark$ PITAŠ, J., \& a kol. Brno, 2. I.-8.-2.-4.-6. (2012). Národní standard kompetencí projektového ř́zení, verze 3.2. Brno: Společnost pro projektové řízení. Dostupné $\mathrm{z}$ : http://www.ipma.cz/wp-content/uploads/2014/10/narodni-standard-kompentenciprojektoveho-rizeni.pdf

$\checkmark$ SCHWALBE, K. (2007). Řízení projektů v IT. Brno: Computer Press.

$\checkmark$ SCHWALBE, K. (2011). Řizení projektů v IT: kompletní průvodce. Brno: Computer Press.

$\checkmark$ SKALICKÝ, J., JERMÁŘ, M. \& SVOBODA, J. (2010). Projektový management a potřebné kompetence. Plzeň: Západočeská univerzita.

\section{Doporučená:}

$\checkmark$ Aktuální literatura podle doporučení garanta předmětu, články z časopisů, příspěvky na konferencích

\section{POŽADAVKY NA STUDENTA}

1. Vstupní požadavky na studenta:

a) Zvládat základní znalosti podnikového managementu.

b) Ovládat pokročilejší funkce programu MS Excel. Znalost MS Project výhodou.

c) Umět uplatnit poznatky ze základů managementu, operačního výzkumu, sociálních a manažerských dovedností a personálního managementu.

2. Aktivní účast minimálně na třech workshopech (bloková výuka), samostudium doporučených zdrojů.

3. Zpracovat písemnou práci (výzkumnou esej) na vybrané téma z oblasti projektového řízení. Vybrané téma a zaměření výzkumné eseje předem konzultovat $s$ garantem předmětu. Rozsah výzkumné eseje 20 -30 stránek A4.

Možná témata semestrálních prací:

- Charakteristika a použití metody kritického řetězce

- Úkoly projektové kanceláře v organizaci

- Management přidané hodnoty - charakteristika, výhody a nevýhody

- Výkonnost projektového řízení - Project Balanced Scorecard

- Project Management Maturity Model

- Management portfolia projektů a programů

- Management kvality

4. Odevzdat finální verzi písemné práce (výzkumné eseje) nejméně jeden týden před závěrečnou konzultací k výsledku písemné práce. 
5. Prokázat získané znalosti, vědomosti a dovednosti při ústní zkoušce, která se skládá z finální prezentace a diskuse výsledků výzkumné eseje a kontrolních otázek v rozsahu témat stanovených sylabem předmětu.

\section{FORMA A ROZSAH VÝUKY}

Výuka předmětu probihá formou blokové prezenční výuky (24 hodin) a individuálních konzultací s garantem predmětu.

1. Obsah 1. výukového bloku, rozsah 6 hodin Viz OBSAH PŘEDMĚTU S DALŠÍ SPECIFIKACÍ, témata 1-4

2. Obsah 2. výukového bloku, rozsah 6 hodin Viz OBSAH PŘEDMĚTU S DALŠÍ SPECIFIKACÍ, témata 5-8

3. Obsah 3. výukového bloku, rozsah 6 hodin Viz OBSAH PŘEDMĚTU S DALŠí SPECIFIKACÍ, témata 9-12

4. Obsah 4. výukového bloku, rozsah 6 hodin Závěrečná konzultace, prezentace a obhajoba písemné práce, závěrečná zkouška a hodnocení

\section{DALŠÍ INFORMACE GARANTA PŘEDMĚTU}

Student je po absolvování předmětu připraven pracovat na vyšších stupních řízení projektů:

- pracovat $v$ oddělení projektového managementu v organizaci,

- rídit projekty s použitím řízení vytvořené hodnoty (Earned Value Management)

- ř́́dit kvalitu projektu,

- rrídit výkonnost projektového managementu pomocí Project Scorecard Method,

- hodnotit vyspělost organizace v řízení projektů,

- rídit portfolia a programy projektů.

Student je připraven k vykonání zkoušek pro získání certifikátu IPMA stupně D.

\section{KONTAKT NA GARANTA PŘEDMĚTU}

\begin{tabular}{|l|l|}
\hline E-mail: & vacekj@kpm.zcu.cz \\
\hline Telefon: & +420 $377633619,+420602120989$ \\
\hline Konzultační hodiny: & (dle aktuálního zadání na www.fek.zcu.cz) \\
\hline Kancelář: & UK 420, FEK ZČU, Univerzitní 22, 30614 Plzeň \\
\hline
\end{tabular}




\section{Management logistických systémů}

\begin{tabular}{|c|c|c|c|c|}
\hline \multicolumn{5}{|c|}{$\begin{array}{r}\text { METODICKÝ LIST PRO PŘEDMĚT DOKTORSKÉHO STUDIJN } \\
\text { EKONOMIKA A MANAGEMENT }\end{array}$} \\
\hline Název předmětu: & \multicolumn{4}{|c|}{ Management logistických systémů } \\
\hline Zkratka předmětu: & \multicolumn{4}{|l|}{ KMO/DMLSN } \\
\hline $\begin{array}{l}\text { Zařazení předmětu do } \\
\text { studijního programu: }\end{array}$ & \multicolumn{3}{|c|}{$\begin{array}{l}\text { Blok A: Povinný předmět } \\
\text { Blok B: Povinně volitelný předmět } \\
\text { Blok C: Volitelný (výběrový) předmět }\end{array}$} & $\begin{array}{l}\square \\
\square \\
\square\end{array}$ \\
\hline Garant: & \multicolumn{3}{|c|}{ doc. Ing. Petr Cimler, CSc. } & \\
\hline Kredity: & \multicolumn{3}{|l|}{10} & \\
\hline Zakončení: & \multicolumn{2}{|l|}{$\begin{array}{l}\text { Zápočet } \\
\text { Zkouška }\end{array}$} & & $\begin{array}{l}\square \\
\square\end{array}$ \\
\hline Forma a rozsah výuky: & $\begin{array}{ll}\text { - } & \text { Přednáška } \\
\text { - } & \text { Seminář } \\
\text { - } & \text { Bloková výuka } \\
\end{array}$ & $\begin{array}{l}\square \\
\square \\
\square\end{array}$ & $\begin{array}{l}\text { Rozsah } \square \text { hodin } \\
\text { Rozsah } \square \text { hodin } \\
\text { Rozsah } 24 \text { hodin }\end{array}$ & \\
\hline Účinnost metodického listu: & od 1.9. 2017 & & & \\
\hline
\end{tabular}

Poskytnout znalosti ke komplexnímu zvládnutí problematiky logistických systémů s výraznějším zaměřením na nákup a prodej, resp. obchodní řetězce; působit na vnímání logistiky jako součásti řízení vztahů se zákazníky; objasnit otázky informačních technologií (přenosů dat), metody prognózování poptávky i ekonomické analýzy logistických výkonů.

\section{OBSAH PŘEDMĚTU}

1. Logistická strategie

2. Řízení toku materiálu

3. Řízení zásob

4. Nákupní logistické procesy

5. Logistické informační systémy

6. Logistické řízení skladování a jeho aspekty

7. Logistický outsourcing a řešení optimalizace logistického řetězce

8. Supply Chain Management (SCM)

9. Logistika nadnárodních obchodních řetězců

10. Obalová logistika

11. Doprava a přeprava v logistice

12. Metody rrízení logistického výkonu 


\section{OBSAH PŘEDMĚTU S DALŠÍ SPECIFIKACÍ}

1. Logistická strategie

a) Výrobní, zásobovací a obchodní logistika

b) Schéma strategického logistického plánu

c) Proces logistického řízení a rozhodování

\section{Klíčová slova:}

integrovaná logistika, místa styku, řetězce

2. Řízení toku materiálu

a) Metody řízení hmotných toků

b) Specifika hmotných toků ve výrobě a oběhu

c) Procesní rízení v logistice

Klíčová slova:

bod rozpojení, procesy, pull, push

3. Řízení zásob

a) Strategie zásobování, objednací systémy

b) Finanční dopady držení zásob

c) Uplatňované statistické metody analýzy zásob a stanovení rídících hladin

Klíčová slova:

dodací cyklus, dodávka, náklady, obrátkovost, zásoba

4. Nákupní logistické procesy

a) Organizace nákupu, racionalizace procesů nákupní logistiky

b) Nákupní strategie, rízení vztahů s dodavateli

c) Nákup v podmínkách internetu

Klíčová slova:

bilance, dodací podmínky, nákup, zdroje

5. Logistické informační systémy

a) Standardy pro identifikaci, sběr dat a jejich sdílení v dodavatelsko-odběratelském řetězci

b) Progresivní systémy vyřizování objednávek, systém elektronické výměny dat (EDI)

c) Vysledovatelnost zboží v oběhu

\section{Klíčová slova:}

data, elektronický dodací list, synchronizace dat

6. Logistické řízení skladování

a) Strategie skladování, veřejné a soukromé skladování

b) Rozmístění skladů, metody operačního výzkumu

c) Crossdocking

Klíčová slova:

kapacita, návaznost, operace, sklad, území

7. Logistický outsourcing

a) Oblasti realizace a využití outsourcingu

b) 2PL, 3PL a 4PL společnosti

c) Praktické uplatnění

Klíčová slova:

koordinace, logistické činnosti, logistický integrátor 
8. Supply Chain Management

a) Externí logistický řetězec

b) Metody řizení logistického řetězce

c) Udržitelné řízení dodavatelského řetězce

\section{Klíčová slova:}

efekt dlouhého biče, řízení vztahů se zákazníky, řízení vztahů s dodavateli, řízení zásob dodavatelem, štíhlá logistika, vyvážení nabídky a poptávky

9. Logistika nadnárodních obchodních řetězců

a) Změny v obsahu vztahů výroba-obchod

b) ECR, podpůrné technologie

c) Praktické uplatnění v obchodě spotřebním zbožím

Klíčová slova:

náklady, odpovědnost, sortiment, účinná odezva, zásobování

10. Obalová logistika

a) Obaly, manipulační a přepravní jednotky v logistice, trendy v technologiích

b) Paletový pool

c) Uplatnění a efekty v logistice

\section{Klíčová slova:}

kontejnerizace, otevřený pool, paletizace, uzavřený pool

11. Doprava a preprava v logistice

a) Přepravní služby

b) Globalizace přepravy

c) Intermodální a kombinovaná přeprava

\section{Klíčová slova:}

dopravce, operátor, přepravce, zasilatel

12. Metody řízení logistického výkonu

a) Výkonový cíl logistiky, vztah ke strategii podniku

b) Způsoby měření logistického výkonu

c) Nákladová stránka logistického výkonu

Klíčová slova:

hospodárnost, kvalita, perfektní dodávka, produktivita, služba, výkon

\section{LITERATURA}

Základní:

Gros, I. (2016). Velká kniha logistiky (1. vydání). Praha: Vysoká škola chemicko-technologická v Praze.

$\checkmark$ Jirsák, P., Mervart, M. \& Vinš, M. (2012). Logistika pro ekonomy. Vstupní logistika (1. vydání). Praha: Wolters Kluwer.

$\checkmark$ Pernica, P. (2005). Logistika pro 21. století: (supply chain management) (1. vydání). Praha: Radix. 


\section{Doporučená:}

$\checkmark$ Bowersox, D. J., Closs, D. J. \& Cooper, M. B. (2013). Supply Chain Logistics Management $\left(4^{\text {th }}\right.$ edition) New York: McGraw-Hill Irwin.

$\checkmark$ Daněk, J. \& Plevný, M. (2005). Výrobní a logistické systémy (1. vydání). Plzeň: Západočeská univerzita.

$\checkmark$ Drahotský, I. \& Řezníček B. (2003). Logistika - procesy a jejich řízení (1. vydání). Brno: Computer Press.

$\checkmark$ Gros, I. \& Grosová, S. (2006). Tajemství moderního nákupu (1. vydání). Praha: Vysoká škola chemicko-technologická v Praze.

$\checkmark$ Christopher, M. (2016). Logistics and Supply Chain Management ( $5^{\text {th }}$ editon). New York: Pearson Education.

$\checkmark$ Lambert, D. M., Stočky, J. R. \& Ellram, L. M. (2005). Logistika: Příkladové studie, řízení zásob, preprava a skladování, balení zboží (1. vydání). Brno: CP Books.

$\checkmark$ Lukoszová, X. (2012). Logistické technologie v dodavatelském řetězci (1. vydání). Praha: Ekopress.

$\checkmark$ Myerson, P. (2012). Lean Supply Chain and Logistics Management ( $1^{\text {st }}$ edition). New York: McGraw-Hill.

$\checkmark$ Nenadál, J. (2006). Management partnerství s dodavateli (1. vydání). Praha: Management Press.

$\checkmark$ Novák, R., Zelený, L., Pernica, P. \& Kolář, P. (2001). Přepravní, zasílatelské a logistické služby (1. vydání). Praha: Wolters Kluwer.

$\checkmark$ Stehlík, A. \& Kapoun, J. (2008). Logistika pro manažery (1. vydání). Praha: Ekopress.

\section{POŽADAVKY NA STUDENTA}

1. Zvládnout předmět $v$ rozsahu stanoveném sylabem a prokázat vědomosti a dovednosti při ústní zkoušce, písemnou prací s výzkumnou orientací a její obhajobou s prezentací.

2. Nastudovat samostatně základní a relevantní doporučené literární zdroje.

3. Zpracovat písemnou práci (výzkumnou esej) na vybrané téma z oblasti logistického řízení firmy. Vybrané téma a zaměření výzkumné eseje předem konzultovat s garantem předmětu. Rozsah výzkumné eseje minimálně 25 - 30 stránek formátu A4.

4. Odevzdat finální verzi písemné práce (výzkumné eseje) v tištěné formě nejméně tři týdny před závěrečnou konzultací s garantem předmětu k výsledku písemné práce.

5. Prokázat získané znalosti, vědomosti a dovednosti při ústní zkoušce, která se skládá z finální prezentace a diskuse výsledků výzkumné eseje a kontrolních otázek $v$ rozsahu témat stanovených sylabem předmětu.

\section{FORMA A ROZSAH VÝUKY}

Výuka předmětu probihá formou blokové prezenční výuky (24 hodin) a individuálních konzultací s garantem predmětu.

1. Obsah 1. výukového bloku, rozsah 6 hodin

a) Logistika, logistické řetězce

b) Řízení materiálových toků - push a pull systém, bod rozpojení

c) Logistická řešení, outsourcing logistických činností

2. Obsah 2. výukového bloku, rozsah 6 hodin

a) Řídící hladiny zásob a jejich stanovení

b) Objednací systémy

c) Analýza zásob 
3. Obsah 3. výukového bloku, rozsah 6 hodin

a) Identifikace zboží v oběhu

b) Systémy elektronické výměny dat, doklady

c) Evropská logistická etiketa

4. Obsah 4. výukového bloku, rozsah 6 hodin

a) Externí logistický řetězec, supply chain management (SCM)

b) Vztahy výroby a obchodu, kooperace v logistickém řetězci, ECR

c) Udržitelná logistika - oblasti uplatnění

\section{DALŠÍ INFORMACE GARANTA PŘEDMĚTU}

\section{KONTAKT NA GARANTA PŘEDMĚTU}

\begin{tabular}{|l|l|}
\hline E-mail: & cimler@kmo.zcu.cz \\
\hline Telefon: & +420377633305 \\
\hline Konzultační hodiny: & (dle aktuálního zadání na www.fek.zcu.cz) \\
\hline Kancelář: & UK 522, FEK ZČU, Univerzitní 22, 306 14 Plzeň \\
\hline
\end{tabular}


Metody a systémy pro podporu rozhodování

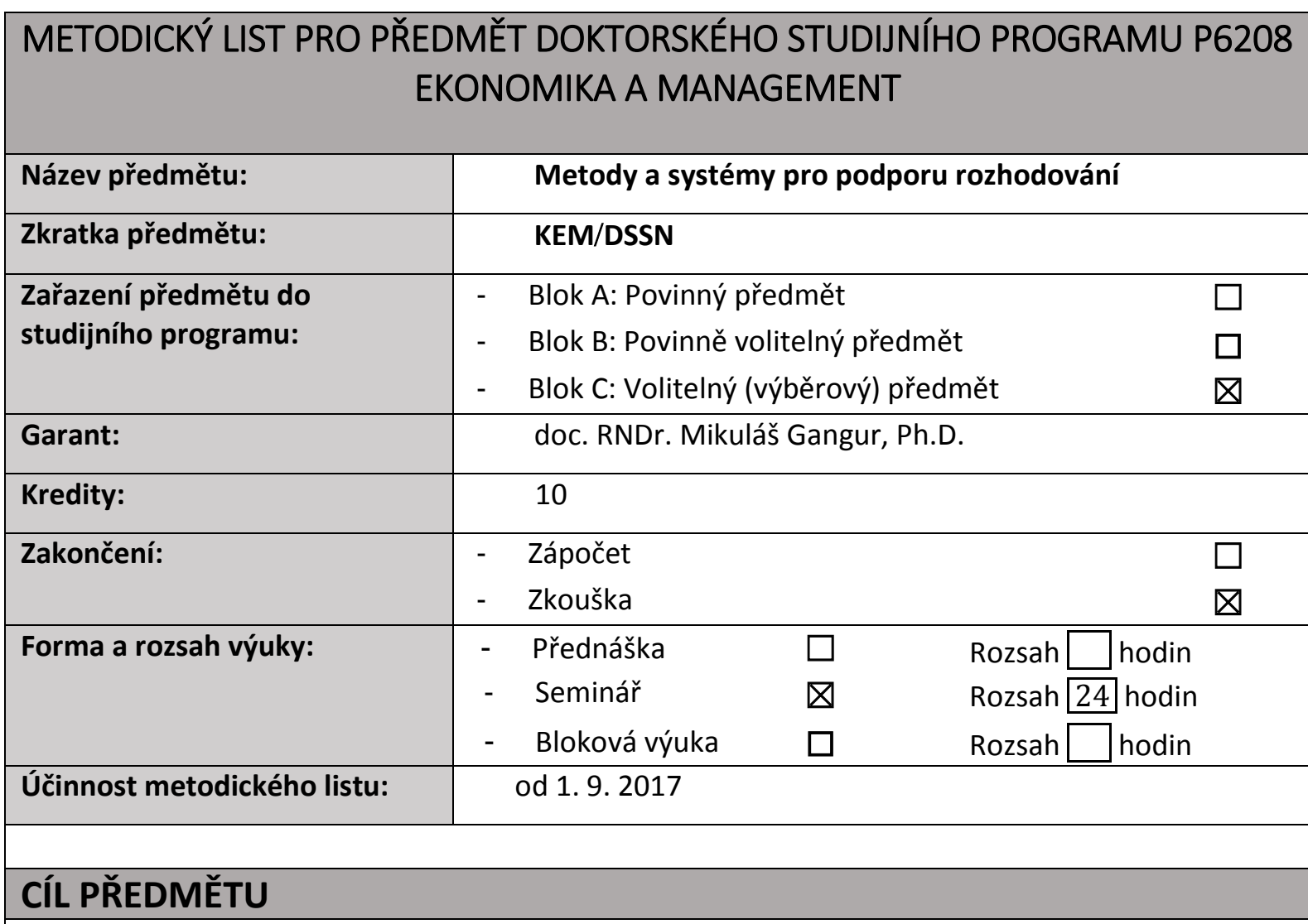

Cílem předmětu je seznámit $s$ metodami, prostředky a systémy pro podporu rozhodování. Dalším cílem je získání dovedností při použití nástrojů, které využívají předložené metody, a jejich praktické využití při rozhodování v podnikové praxi.

\section{OBSAH PŘEDMĚTU}

1. Využití informace a znalosti v rozhodovacích procesech

2. Proces dobývání znalostí z databází, metodika CRISP-DM

3. Zdroje dobývání znalostí: databáze, statistické metody, strojové učení

4. Metody strojového učení: rozhodovací stromy, rozhodovací pravidla, asociační pravidla, neuronové sítě, genetické algoritmy, bayesovské metody učení

5. Využití statistických nástrojů a nástrojů strojového učení v SW Statistica a SW Mathematica

6. Způsoby hodnocení sestrojených modelů

7. Metody prípravy dat

8. Přehled systémů pro dobývání znalostí z databází

9. Principy systémů pro podporu rozhodování (Decision Support System - DSS)

10. Nástroje pro tvorbu systémů pro podporu rozhodování

11. Prediktivní trhy, principy a využití v DSS 


\section{OBSAH PŘEDMĚTU S DALŠÍ SPECIFIKACÍ}

1. CRISP-DM

a) Popis metody

b) Jednotlivé fáze konstrukce modelu

c) Časová náročnost

d) Hotové nástroje data miningu

\section{Klíčová slova:}

CRISP-DM, data mining

2. Zdroje znalostí a zpracování dat

a) Databáze, SQL, no-SQL, big data

b) Statistické metody

c) Základy strojového učení

\section{Klíčová slova:}

big data, no-SQL, SŘBD

3. Metody data miningu - DM

a) Přehled vybraných metod DM a principy jejich činnosti

b) Srovnání nástrojů DM ve vybraných SW

c) Praktická aplikace vybraných metod na zkušební data pro daný nástroj

Klíčová slova:

data mining, nástroje DM, SW Mathematica, SW Matlab, SW Statistica,

4. Práce s daty

a) Metody prípravy dat - explorační analýza dat - EDA

b) Sestavení modelů a jejich testování

c) Hodnocení úspěšnosti jednotlivých modelů

d) Aplikace modelů na praktických datech

Klíčová slova:

EDA, evaluace modelu, konstrukce modelu, modifikace modelu

5. Přehled hotových řešení.

a) Systémy pro dobývání znalostí z databází - výhody a nevýhody

b) Systémy pro podporu rozhodování - DSS - praktické aplikace a využití

c) Přehled nástrojů pro tvorbu DSS

Klíčová slova:

dobývání znalostí z DB, DSS

6. Prediktivní trhy

a) Princip, popis a použití prediktivních trhů

b) Vybrané otázky problematiky prediktivních trhů - motivační systémy, přesnost predikce

likvidita prediktivního trhu, různé finanční systémy na prediktivním trhu

c) Prediktivní trh jako součást DSS

Klíčová slova:

automatický tvůrce trhu - AMM, motivační a pobídkový systém, prediktivní trh, průběžná dvojitá aukce - CDA 


\section{LITERATURA}

\section{Základní:}

Rud, O. P. (2001). Data mining: praktický průvodce dolováním dat pro efektivní prodej, cílený marketing a podporu zákazníků (CRM). (1. vydání). Praha: Computer Press.

$\checkmark$ Berka, P. (2003). Dobývání znalostí z databází (1. vydání). Praha: Academia.

$\checkmark$ Hebák, P. \& kol. (2013). Statistické myšlení a nástroje analýzy dat (1. vydání). Praha: Informatorium.

\section{Doporučená:}

$\checkmark$ Rokach, L. \& Maimon, O. (2008). Data mining with decision trees: theory and applications. Hackensack: World Scientific.

$\checkmark$ Gangur, M. (2015). Prediktivní trhy: principy, struktura a využití prediktivních trhů: pobídkové a motivační systémy prediktivních trhů: problematika implementace prediktivního trhu (1. vydání). Praha: Wolters Kluwer.

$\checkmark$ Hendl, J. (2015). Přehled statistických metod: analýza a metaanalýza dat (5. rozšířené vydání). Praha: Portál.

\section{POŽADAVKY NA STUDENTA}

1. Samostudium doporučených zdrojů a e-learning.

2. Zpracování semestrální práce dle zaměření studenta (rozsah práce je 15 - 20 normostran).

3. Zkouška je formou obhajoby uvedené semestrální práce a dále dle okruhů.

\section{FORMA A ROZSAH VÝUKY}

Výuka predmětu probíhá formou blokové prezenční výuky (24 hodin) a individuálních konzultací s garantem předmětu.

1. Obsah 1. volitelného výukového bloku, rozsah 4 hodiny

a) Základní kurz ovládání SW Statistica

b) Základní kurz ovládání SW Matlab

c) Základní kurz ovládání SW Mathematica

2. Obsah 2. výukového bloku, rozsah 6 hodin

a) Metodika CRISP-DM a její využití

b) Přehled metod data miningu a principy jejich činnosti

c) Aplikace těchto metod ke konstrukci modelů ve vybraném SW, testy na zkušebních datech a jejich srovnání (SW Statistica)

d) Samostatná práce v podobě konstrukce modelů v dalších SW (Mathematica, Matlab)

3. Obsah 3. výukového bloku, rozsah 6 hodin

a) Sběr dat a jejich prííprava pro další zpracování

b) Volba vhodné metody a konstrukce modelu

c) Testování modelu a jeho vyhodnocení

d) Konstrukce modelů v dalším SW a srovnání výsledků

4. Obsah 4. výukového bloku, rozsah 4 hodiny. Prezentace vybraných systémů.

a) Přehled nástrojů a systémů pro dobývání znalostí z databází

b) Přehled DSS a jejich aktuální praktické využití v organizacích

c) Využití nástrojů pro konstrukci DSS systémů 
5. Obsah 5. výukového bloku, rozsah 4 hodiny

a) Prediktivní trhy - principy, použití, využití v DSS

b) Různé finanční struktury trhu, motivační a pobídkové systémy

c) Praktická ukázka různých prediktivních trhů a návrh rozšiřujících funkcionalit

\section{DALŠí INFORMACE GARANTA PŘEDMĚTU}

Práce studentů se kromě dostupné literatury v českém jazyce a podpory používaného SW opírá zejména o zpracování aktuálních zdrojů $v$ podobě článků odborně zaměřených časopisů, technických zpráv apod.

U studentů se předpokládá základní úroveň práce v SW Matlab, Statistica a Mathematica. Pro zájemce je možné doplnit si znalosti základů ovládání těchto systémů.

\section{KONTAKT NA GARANTA PŘEDMĚTU}

\begin{tabular}{|l|l|}
\hline E-mail: & gangur@kem.zcu.cz \\
\hline Telefon: & 377633167 \\
\hline Konzultační hodiny: & (dle aktuálního zadání na www.fek.zcu.cz) \\
\hline Kancelář: & UK 425, FEK ZČU, Univerzitní 22, 306 14 Plzeň \\
\hline
\end{tabular}


Kvalitativní a smíšený výzkum v ekonomii

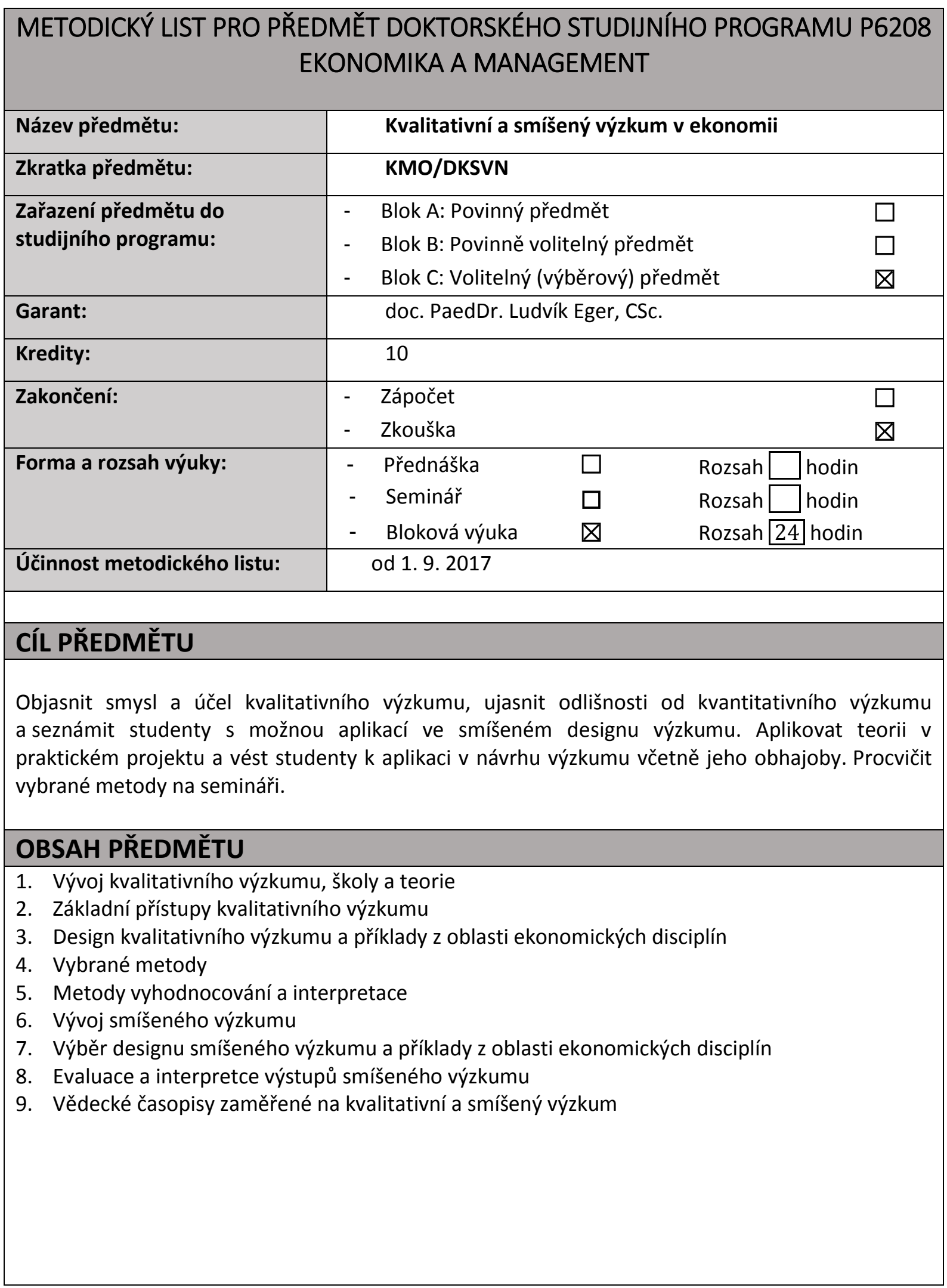




\section{OBSAH PŘEDMĚTU S DALŠÍ SPECIFIKACÍ}

1. Vývoj kvalitativního výzkumu, školy a teorie

a) Výhody a nevýhody kvalitativního výzkumu

b) Čísla versus slova

c) Současné inovace v kvalitativním výzkumu, využívání ICT

\section{Klíčová slova:}

kvalitativní výzkum, inovace kvalitativního výzkumu

2. Základní př́stupy kvalitativního výzkumu

a) Paradigma, strategie v kvalitativním výzkumu

b) Zajištění kvality výzkumu, triangulace

Klíčová slova:

paradigma, strategie kvalitativního výzkumu, triangulace

3. Design kvalitativního výzkumu a príklady z oblasti ekonomických disciplín
a) Design prípadových studií
b) Další designy kvalitativního výzkumu
c) Role výzkumníka
d) Sběr dat v kvalitativním výzkumu
e) Etika

Klíčová slova:

design výzkumu, prípadová studie, role výzkumníka, etické otázky

4. Vybrané metody

a) Hloubkové rozhovory, panelová diskuse (inovace s využitím internetu a mobilních zařízení)

b) Zúčastněné a nezúčastněné pozorování

c) Projektivní techniky

d) Neuromarketing a aplikace eyetrackingu

\section{Klíčová slova:}

hloubkové rozhovory, zúčastněné pozorování, projektivní techniky, eyetacking

5. Metody vyhodnocování a interpretace

a) Rozdíl mezi kvantitativními a kvalitativními daty

b) Přístupy ke kvalitativní analýze

d) Metody vyhodnocování a interpretace dat

c) Softwarové nástroje pro analýzu kvalitativních dat

Klíčová slova:

kvalitativní analýza, kódování, deduktivní a induktivní procedury, software

6. Vývoj smíšeného výzkumu

a) Rozdíly v kvalitativním a kvantitativním výzkumu

b) Typy smíšeného výzkumu

c) Pragmatismus a smíšená strategie výzkumu

Klíčová slova:

smíšený výzkum, typy smíšeného výzkumu, aplikace smíšeného výzkumu 
7. Výběr designu smíšeného výzkumu a príklady z oblasti ekonomických disciplín

a) Př́klady inovativního využití smíšeného výzkumu v ekonomických disciplínách

b) Klíčová rozhodnutí při výběru designu

c) Hodnocení výhod a nevýhod smíšeného výzkumu, diskuse

\section{Klíčová slova:}

aplikace smíšeného výzkumu, plán smíšeného výzkumu

8. Evaluace a interpretce výstupů smíšeného výzkumu

a) Sběr dat ve smíšeném výzkumu

b) Příprava, prozkoumání, analýza, validace dat

c) Strategie pro komparaci a interpretaci smíšeného výzkumu

Klíčová slova:

analýza dat, interpretace dat, prezentace výsledků smíšeného výzkumu

9. Vědecké časopisy zaměěené na kvalitativní a smíšený výzkum

a) Práce s literaturou, využití ICT

Klíčová slova:

práce se zdroji, metodologie výzkumu

\section{LITERATURA}

\section{Základní:}

Cresewell, W. J. \& Plano-Clark, L. W. (2011). Designing and Conducting Mixed Methods Research. London: SAGE.

$\checkmark$ Hendl, J. (2008). Základní teorie, metody a aplikace. Praha: Portál.

$\checkmark$ Hendl, J. \& Remr, J. (2017). Metody výzkumu a evaluace. Praha: Portál.

$\checkmark$ Saunders, M. \& Lewis, P. (2009). Research methods for business students. Harlow: Prentice Hall.

\section{Doporučená:}

$\checkmark$ Burns, C. A., Veeck, A. \& Bush, F. R. (2017). Marketing Research. London: Pearson.

$\checkmark$ Creswell, J. W. (2009). Research design: qualitative, quantitative, and mixed methods approaches. Thousand Oaks: SAGE.

$\checkmark$ Punch, K. (2008). Úspěšný návrh výzkumu. Praha: Portál.

$\checkmark \quad$ Eger, L. \& Egerová, D. (2014). Základy metodologie výzkumu. Plzeň: ZČU v Plzni.

$\checkmark$ Hendl, J. \& kol. (2014). Statistika v aplikacích. Praha: Portál.

\section{POŽADAVKY NA STUDENTA}

1. Aktivní účast minimálně na dvou blocích výuky, samostudium doporučených zdrojů.

2. Zpracování semestrální práce dle zaměření studenta (rozsah práce je 15 - 20 normostran).

3. Zkouška je formou obhajoby uvedené semestrální práce a dále dle okruhů viz STAG. 


\section{FORMA A ROZSAH VÝUKY}

Výuka předmětu probíhá formou blokové prezenční výuky (24 hodin) a individuálních konzultací s garantem predmětu.

1. Obsah 1. výukového bloku, rozsah 6 hodin

a) Kvalitativní výzkum

b) Příklady aplikací kvalitativního výzkumu v ekonomických disciplínách

c) Využívání kvalitativních metod pro porozumění jevům nebo respondentům

2. Obsah 2. výukového bloku, rozsah 6 hodin
a) Zakotvená teorie
b) Analýza dat s využitím software
c) Seminární cvičení ve vztahu k tématu disertace
d) Prezentace výstupů

3. Obsah 3. výukového bloku, rozsah 6 hodin

a) Eyetracking, základní výcvik

b) Př́prava výzkumu, realizace kvalitativní studie, vyhodnocení, zpracování závěrů

c) Pozorování, zúčastněné pozorování, príprava průzkumu

4. Obsah 4. výukového bloku, rozsah 6 hodin

a) Smíšený výzkum

b) Příklady smíšeného výzkumu, studium relevantních zdrojů

c) Výběr designu a príprava návrhu výzkumu, prezentace návrhu a diskuse

\section{DALŠÍ INFORMACE GARANTA PŘEDMĚTU}

Bloková výuka bloků 2 a 3 je spojena s využíváním technického a softwarového vybavení fakulty.

\section{KONTAKT NA GARANTA PŘEDMĚTU}

\begin{tabular}{|l|l|}
\hline E-mail: & leger@kmo.zcu.cz \\
\hline Telefon: & +420377633312 \\
\hline Konzultační hodiny: & (dle aktuálního zadání na www.fek.zcu.cz) \\
\hline Kanceláŕ: & UK 518, FEK ZČU, Univerzitní 22, 306 14 Plzeň \\
\hline
\end{tabular}


Podnikové informační systémy

\section{METODICKÝ LIST PRO PŘEDMĚT DOKTORSKÉHO STUDIJNÍHO PROGRAMU P6208 EKONOMIKA A MANAGEMENT}

\begin{tabular}{|c|c|c|c|c|}
\hline Název předmětu: & \multicolumn{4}{|c|}{ Podnikové informační systémy } \\
\hline Zkratka předmětu: & \multicolumn{4}{|l|}{ FEK/DPISN } \\
\hline $\begin{array}{l}\text { Zařazení předmětu do } \\
\text { studijního programu: }\end{array}$ & \multicolumn{3}{|c|}{$\begin{array}{l}\text { Blok A: Povinný předmět } \\
\text { - } \quad \text { Blok B: Povinně volitelný předmět }\end{array}$} & $\begin{array}{l}\square \\
\square \\
\square\end{array}$ \\
\hline Garant: & \multicolumn{3}{|c|}{ prof. Ing. Josef Basl, CSc. } & \\
\hline Kredity: & \multicolumn{3}{|l|}{10} & \\
\hline Zakončení: & \multicolumn{2}{|l|}{$\begin{array}{ll} & \text { Zápočet } \\
\text { - } & \text { Zkouška }\end{array}$} & & $\begin{array}{l}\square \\
\square\end{array}$ \\
\hline Forma a rozsah výuky: & $\begin{array}{ll}\text { - } & \text { Přednáška } \\
\text { - } & \text { Seminář } \\
\text { - } & \text { Bloková výuka }\end{array}$ & $\begin{array}{l}\square \\
\square \\
\square\end{array}$ & $\begin{array}{l}\text { Rozsah } \square \text { hodin } \\
\text { Rozsah } \square \text { hodin } \\
\text { Rozsah } 24 \text { hodin }\end{array}$ & \\
\hline Účinnost metodického listu: & \multicolumn{3}{|l|}{ od 1. 9. 2017} & \\
\hline CÍL PŘEDMĚTU & & & & \\
\hline
\end{tabular}

\section{OBSAH PŘEDMĚTU}

1. Vývojové etapy digitalizace podniků

2. Podnik v informační společnosti

3. Pojetí a typologie podnikových informačních systémů

4. Hlavní aplikační SW řešení podnikových IS - horizontální integrace

5. Hlavní aplikační SW řešení podnikových IS - vertikální integrace

6. Procesní pojetí podnikových IS

7. Datové pojetí podnikových IS a podpora rozhodování

8. Metody aplikované $v$ podnikových informačních systémech

9. Strategické řízení IS v podniku

10. Implementace IS do podniku

11. Hodnocení efektů podnikových IS

12. Potenciál rizik

13. Inovace podnikových informačních systémů 


\section{OBSAH PŘEDMĚTU S DALŠÍ SPECIFIKACÍ}

1. Vývojové etapy digitalizace podniků
a) Historie digitalizace podniků
b) Vývojové etapy podnikových IS
c) Od Enterprise $2.0 \mathrm{k}$ Industry 4.0

2. Podnik v informační společnosti
a) Technologické trendy informační společnosti
b) Prognózy a statistiky informační společnosti
c) Indexy připravenosti

3. Pojetí a typologie podnikových informačních systémů
a) Definice podnikových IS
b) Kategorie aplikací
c) Architektury podnikové informatiky

4. Hlavní aplikační SW řešení podnikových IS - horizontální integrace
a) ERP
b) SCM, CRM
c) PLM

5. Hlavní aplikační SW řešení podnikových IS - vertikální integrace
a) Analytická řešení - BI
b) Transakční řešení - ERP
c) Sensory, APS, MES, WMS

6. Procesní pojetí podnikových IS
a) Podnikové procesy a jejich podpora podnikovými IS
b) Zralost a metriky procesů
c) Zlepšování podnikových procesů

7. Datové pojetí podnikových IS a podpora rozhodování
a) Typy dat a způsoby jejich zpracování
b) Podpora rozhodování - BI
c) Další podpora rozhodování $-\mathrm{Cl}, \mathrm{Al}$

8. Metody aplikované $v$ podnikových informačních systémech
a) Metody implementované v podnikových IS
b) Metody podporované podnikovými IS
c) Metody podporující implementaci podnikových IS

9. Strategické ř́zení IS v podniku
a) ICT strategie podniku
b) Strategické řízení podnikového IT
c) Enterprise architektura 
10. Implementace IS do podniku
a) Projekt implementace podnikového IS
b) Výběr vhodných řešení a jejich dodavatelů
c) Ǩešení on promise a řešení jako služba

11. Hodnocení efektů podnikových IS
a) Lean prístupy
b) Prrístupy dle TOC
c) Green prístupy

12. Potenciál rizik
a) Technologická, procesní, datová, funkční
b) Uživatelská
c) Bezpečnostní, legislativní

13. Inovace podnikových informačních systémů
a) Typologie a rády inovací a inovátorů
b) Trendy v oblasti podnikových IS
c) Celospolečenské trendy a prognózy rozvoje

\section{LITERATURA}

\section{Základní:}

Basl, J. \& Blažíček, R. (2012) Podnikové informační systémy: podnik v informační společnosti. (3. aktualizované a doplněné vydání). Praha: Grada.

$\checkmark$ Basl, J. \& kol. (2011). Inovace podnikových informačních systémů: podpora konkurenceschopnosti podniků. (1. vydání). Praha: Professional Publishing.

\section{Doporučená:}

$\checkmark$ Moore, G. A. (2005). Dealing with Darwin: How Great Companies Innovate at Every Phase of Their Evolution. New York: Portfolio, Penguin Group.

$\checkmark$ Friedman, T. L. (2006). The World is Flat - The Globalized World in the Twenty-first Century. $\left(2^{\text {nd }}\right.$ edition). London: Penguin Books.

\section{POŽADAVKY NA STUDENTA}

\section{Proaktivní príprava na výuku.}

2. Zpracování eseje.

3. Zpracování a obhájení projektu inovace podnikového informačního systému.

\section{FORMA A ROZSAH VÝUKY}

Výuka předmětu probíhá formou blokové prezenční výuky (24 hodin) a individuálních konzultací s garantem predmětu.

1. Obsah 1. výukového bloku, rozsah 6 hodin
a) Vývoj podnikových IS
b) Klíčové milníky rozvoje podnikového IS
c) Trendy, statistiky, indexy připravenosti

2. Obsah 2. výukového bloku, rozsah 6 hodin 
a) Hlavní aplikace podnikových IS

b) Hlavní oblasti integrace

c) Procesní a datový pohled

3. Obsah 3. výukového bloku, rozsah 6 hodin
a) Řízení rozvoje podnikového IS
b) Projekt implementace rozvoje podnikového IS
c) Př́nosy a rizika rozvoje podnikových IS

4. Obsah 4. výukového bloku, rozsah 6 hodin

a) Inovace podnikového IT

b) Trendy dalšího rozvoje podnikových IS

c) Celospolečenské trendy rozvoje

\section{DALŠí INFORMACE GARANTA PŘEDMĚTU}

\section{KONTAKT NA GARANTA PŘEDMĚTU}

\begin{tabular}{|l|l|}
\hline E-mail: & Basljo@kpv.zcu.cz \\
\hline Telefon: & +420377638426 \\
\hline Konzultační hodiny: & (dle aktuálního zadání na www.fek.zcu.cz) \\
\hline Kancelář: & UK 326, FST ZČU, Univerzitní 22, 306 14 Plzeň \\
\hline
\end{tabular}


Kooperace v mezinárodním vědeckém týmu

\section{METODICKÝ LIST PRO PŘEDMĚT DOKTORSKÉHO STUDIJNÍHO PROGRAMU P6208 EKONOMIKA A MANAGEMENT}

\begin{tabular}{|c|c|c|c|c|c|}
\hline Název předmětu: & \multicolumn{5}{|c|}{ Kooperace v mezinárodním vědeckém týmu } \\
\hline Zkratka předmětu: & \multicolumn{5}{|l|}{ FEK/DKON } \\
\hline $\begin{array}{l}\text { Zařazení předmětu do } \\
\text { studijního programu: }\end{array}$ & \multicolumn{3}{|c|}{$\begin{array}{ll}\text { - } & \text { Blok A: Povinný předmět } \\
\text { - } & \text { Blok B: Povinně volitelný předmět } \\
\text { - } & \text { Blok C: Volitelný (výběrový) předmět }\end{array}$} & & $\begin{array}{l}\square \\
\square \\
\square\end{array}$ \\
\hline Garant: & \multicolumn{4}{|c|}{ doc. Dr. Ing. Miroslav Plevný } & \\
\hline Kredity: & \multicolumn{3}{|l|}{10} & & \\
\hline Zakončení: & \multicolumn{3}{|l|}{$\begin{array}{ll}\text { - } & \text { Zápočet } \\
\text { - } & \text { Zkouška }\end{array}$} & & $\begin{array}{l}\bigotimes \\
\square\end{array}$ \\
\hline Forma a rozsah výuky: & $\begin{array}{ll}\text { - } & \text { Přednáška } \\
\text { - } & \text { Seminář } \\
\text { - } & \text { Bloková výuka }\end{array}$ & $\begin{array}{l}\square \\
\square \\
\square\end{array}$ & $\begin{array}{l}\text { Rozsah } \\
\text { Rozsah } \\
\text { Rozsah }\end{array}$ & $\begin{array}{l}\text { hodin } \\
\text { hodin } \\
\text { hodin }\end{array}$ & \\
\hline Účinnost metodického listu: & \multicolumn{5}{|l|}{ od 1.9. 2017} \\
\hline \multicolumn{6}{|l|}{ CÍL PŘEDMĚTU } \\
\hline \multicolumn{6}{|c|}{$\begin{array}{l}\text { Realizovat aktivní účast studenta ve spolupráci se školitelem na vyhledání a přípravě podmínek pro } \\
\text { účast studenta na zahraniční stáži a následně absolvovat tuto stáž na odpovídajícím univerzitním } \\
\text { nebo vědeckém pracovišti. Alternativně (zejména pro kombinovanou formu studia) zapojit } \\
\text { studenta do aktivní kooperace v týmu mezinárodního výzkumného projektu, který souvisí se } \\
\text { studovaným oborem. }\end{array}$} \\
\hline
\end{tabular}

\section{OBSAH PŘEDMĚTU}

1. Příprava na zahraniční stáž

2. Vlastní účast na odborné stáži (popř. více kratších odborných stáží) v zahraničí v celkovém rozsahu minimálně 30 dnů na odpovídajícím univerzitním nebo vědeckém pracovišti

3. Alternativně jde o aktivní kooperaci $v$ týmu mezinárodního vědeckého projektu, $v$ projektu Visegrad Fund, projektu podporovaném EU či jiném externím projektu realizovaném minimálně $v$ príhraničním působení, $v$ trvání minimálně 1 roku, jehož charakter je vědecký $a$ souvisí se studovaným oborem

4. Podstatnou součástí je zpracování sebe-evaluační zprávy a pohovor se školitelem či proděkanem o zkušenostech z realizované činnosti

\section{OBSAH PŘEDMĚTU S DALŠÍ SPECIFIKACÍ}

$\checkmark \quad$ Bez bližší specifikace. 


\begin{tabular}{|c|c|}
\hline \multirow{2}{*}{\multicolumn{2}{|c|}{$\begin{array}{l}\text { LITERATURA } \\
\text { Základní: }\end{array}$}} \\
\hline & Základní: \\
\hline \multicolumn{2}{|c|}{$\begin{array}{l}\checkmark \text { Směrnice děkana Fakulty ekonomické ZČU "Organizace studia v doktorském studijním } \\
\text { programu" v aktuálně platném znění. }\end{array}$} \\
\hline \multicolumn{2}{|l|}{ Doporučená: } \\
\hline \multicolumn{2}{|c|}{ POŽADAVKY NA STUDENTA } \\
\hline \multicolumn{2}{|c|}{$\begin{array}{l}\text { 1. Účast na zahraniční stáži či zapojení se do týmu mezinárodního výzkumného projektu za } \\
\text { podmínek specifikovaných obsahem tohoto předmětu. } \\
\text { 2. Zpracování sebe-evaluační zprávy z realizované činnosti a její odsouhlasení školitelem či } \\
\text { garantem tohoto předmětu. }\end{array}$} \\
\hline \multicolumn{2}{|c|}{ FORMA A ROZSAH VÝUKY } \\
\hline \multicolumn{2}{|c|}{$\begin{array}{l}\text { Podstatou předmětu není přímá výuka. Organizace zahraniční stáže či zapojení do mezinárodního } \\
\text { výzkumného projektu realizuje student v součinnosti se školitelem či prípadně jinými } \\
\text { akademickými pracovníky fakulty. }\end{array}$} \\
\hline \multicolumn{2}{|c|}{ DALŠí INFORMACE GARANTA PŘEDMĚTU } \\
\hline \multicolumn{2}{|c|}{ KONTAKT NA GARANTA PŘEDMĚTU } \\
\hline E-mail: & plevny@kem.zcu.cz \\
\hline Telefon: & 377633501 \\
\hline Konzultační hodiny: & (dle aktuálniho zadání na www.fek.zcu.cz) \\
\hline Kancelář: & $\begin{array}{l}\text { UK } 421 \text {, FEK ZČU, Univerzitní 22, } 30614 \text { Plzeň } \\
\text { CD } 301 \text {, FEK ZČU, Hradební 22, } 35011 \text { Cheb }\end{array}$ \\
\hline
\end{tabular}




\section{SHRNUTÍ}

Publikace Metodické listy pro předměty doktorského studijního programu P6208 Ekonomika a management představuje aktuální stav zaměření a obsahu doktorského studijního programu na Fakultě ekonomické Západočeské univerzity v Plzni v kreditním systému studia.

V publikaci jsou představeny cíle, detailní obsah, literatura, počet kreditů, způsob absolvování a požadavky na studium povinných, povinně-volitelných a volitelných předmětů čtyřletého doktorského studijního programu včetně časového doporučení pro zařazení předmětu do studijního plánu studenta doktorského studijního programu.

Metodické listy kjednotlivým předmětům reagují na informační potřeby studentů doktorského studijního programu v kreditním systému studia a ve svém celkovém obsahu reagují na současné požadavky na výzkumnou, vývojovou, pedagogickou a tvưrčí činnost studentů doktorského studia. 